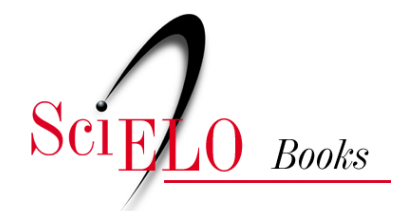

\title{
Literatura brasileira em foco VIII outras formas de escrita
}

\author{
Andréa Sirihal Werkema \\ Fátima Cristina Dias Rocha \\ Leonardo Davino de Oliveira \\ (Organizadores)
}

WERKEMA, A.S., ROCHA, F.C.D., and OLIVEIRA, L.D., eds. Literatura brasileira em foco VIII: outras formas de escrita [online]. Rio de Janeiro: EdUERJ, 2018, 190 p. ISBN 978-85-7511-487-2. https://doi.org/10.7476/9788575114872.

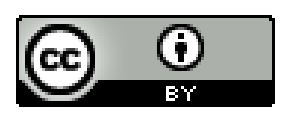

All the contents of this work, except where otherwise noted, is licensed under a Creative Commons Attribution 4.0 International license.

Todo o conteúdo deste trabalho, exceto quando houver ressalva, é publicado sob a licença Creative Commons Atribição $\underline{4.0}$.

Todo el contenido de esta obra, excepto donde se indique lo contrario, está bajo licencia de la licencia Creative Commons $\underline{\text { Reconocimento } 4.0 .}$. 
LITERATURA BRASILEIRA EM FOCO VIII outras formas de escrita 


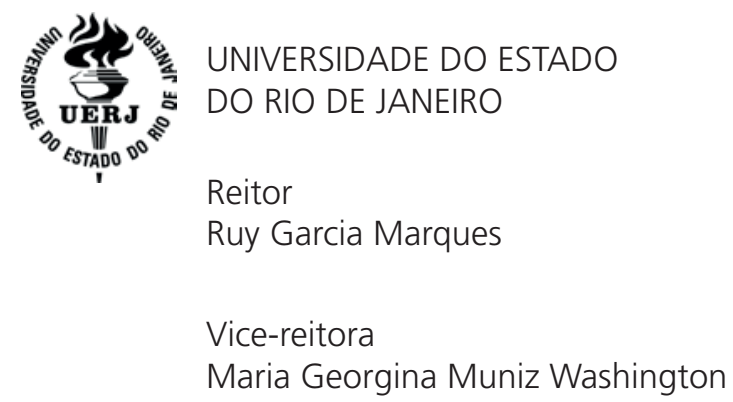

$\begin{array}{ll}\text { ed } & \text { EDITORA DA UNIVERSIDADE DO } \\ \text { uer } & \text { ESTADO DO RIO DE JANEIRO }\end{array}$

Conselho Editorial

Glaucio José Marafon (presidente)

Henriqueta do Coutto Prado Valladares

Hilda Maria Montes Ribeiro de Souza

Italo Moriconi Junior

José Ricardo Ferreira Cunha

Lucia Maria Bastos Pereira das Neves

Luciano Rodrigues Ornelas de Lima

Maria Cristina Cardoso Ribas

Tania Maria Tavares Bessone da Cruz Ferreira

Anibal Francisco Alves Bragança (EdUFF)

Katia Regina Cervantes Dias (UFRJ) 


\section{LITERATURA BRASILEIRA EM FOCO VIII outras formas de escrita}

organização

Andréa Sirihal Werkema

Fátima Cristina Dias Rocha

Leonardo Davino de Oliveira

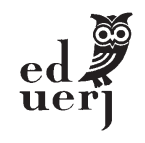

Rio de Janeiro 2018 
Copyright (C) 2018, Dos autores.

Todos os direitos desta edição reservados à Editora da Universidade do Estado do Rio de Janeiro. É proibida a duplicação ou reprodução deste volume, ou de parte do mesmo, em quaisquer meios, sem autorização expressa da editora.

EdUERJ

Editora da UNIVERSIDADE DO ESTADO DO RIO DE JANEIRO

Rua São Francisco Xavier, 524 - Maracanã

CEP 20550-013 - Rio de Janeiro - RJ - Brasil

Tel./Fax.: 55 (21) 2334-0720 / 2334-0721

www.eduerj.uerj.br

eduerj@uerj.br

Editor Executivo

Coordenadora Administrativa

Coordenadora Editorial

Coordenador de Produção

Supervisor de Revisão

Assistente Editorial

Assistente de Produção

Revisão

Projeto Gráfico e Diagramação

Capa

Glaucio Marafon

Elisete Cantuária

Silvia Nóbrega

Mauro Siqueira

Elmar Aquino

Thiago Braz

Érika Neuschwang

João Martorelli

Mauro Siqueira

Mauro Siqueira

DADOS INTERNACIONAIS DE CATALOGAÇÃO NA PUBLICAÇÃO(CIP)

L775 Literatura brasileira em foco VIII : outras formas de escrita [recurso eletrônico] / organização Andréa Sirihal Werkema, Fátima Cristina Dias Rocha, Leonardo Davino de Oliveira. Rio de Janeiro : EdUERJ, 2018.

1 recurso online (192 p.) : PDF.

e-ISBN 978-85-7511-487-2

1. Literatura brasileira. 2. Literatura - História e crítica - Teoria, etc. I. Werkema, Andréa Sirihal. II. Rocha, Fátima Cristina Dias. III. Oliveira, Leonardo Davino de, 1978-.

CDU 821.134.3(81)

Bibliotecária: Leila Andrade CRB7/4016 


\section{Sumário}

\section{Apresentação}

13 Reinvenções poéticas pelo humor Marília Rothier Cardoso

27 Machado de Silviano (o texto de Estela para o pai) Ana Chiara

45 "Até os penhascos duros respondem": breve introdução à epistolografia de Antônio Vieira Ana Lúcia Machado de Oliveira

63 Crítica literária: descrição, recriação, análise Andréa Sirihal Werkema

77 O ensaio de Eduardo Prado na Revista de Portugal anterior à publicação de Fastos da ditadura militar no Brasil Éverton Barbosa Correia

99 O conto zero e outras histórias e Pai, paí. Sérgio Sant'Anna e João Silvério Trevisan visitam o "museu da memória" Fátima Cristina Dias Rocha 
121 Ruas, quartos, janelas: Manuel Bandeira espia Giovanna Dealtry

137 Hilda Hilst: passos da consagração Italo Moriconi

147 Crônicas, cantos e outras críticas do sujeito cancional Leonardo Davino de Oliveira

167 Notas sobre a escrita da crônica no Brasil: 1830-1930 Marcus Vinicius Nogueira Soares

187 Sobre os autores 
Apresentação 
Com esta edição, chega ao oitavo volume a série Literatura brasileira em foco, que, inaugurada em 2003, reúne a produção intelectual da equipe de professores que atuam no Curso de Pós-Graduação lato sensu em Literatura Brasileira. Criado no início dos anos 1980, o Curso de Especialização em Literatura Brasileira permanece vivo e atuante, contando com professores do Instituto de Letras da UERJ e com professores convidados, oriundos de outras instituições de ensino superior. Procurando abordar conteúdos relevantes e atuais, o Curso de Especialização em Literatura Brasileira desenvolve-se em torno de um tema, examinando-o sob os mais diversos ângulos. A série Literatura brasileira em foco dedica-se, em cada edição, ao tema contemplado no Curso. Assim, este oitavo volume da série volta-se para outras formas de escrita da literatura.

O trabalho na Especialização em Literatura Brasileira da UERJ é sempre prazeroso, por trazer a nós, professores, um retorno inegável. Nossos alunos insistem em manter vivo um curso que tem enfrentado, assim como todos os cursos, em todos os níveis de ensino da UERJ, o descaso do Estado, a pressão para o desmonte da universidade pública - é público e notório o modo como tem sido tratada a educação nos últimos anos no Brasil e no Estado 
do Rio de Janeiro. A UERJ, sabemos todos, tem sofrido, tem acumulado perdas. Mas nossos alunos dizem não ao desmonte: a resposta vem em excelência, em diversidade, em ensino de alta qualidade. $\mathrm{E}$ assim se faz a permanência de um debate imprescindível para a universidade, na discussão e na pesquisa, que tem como objeto as questões da literatura brasileira. Nós, professores de um curso que se mantém, a despeito de todos os ataques e de todas as tentativas de sucateamento de nossa universidade, sabemos que nossa força está na variedade dos temas literários que são apresentados a cada ano para nossos alunos, nas relações estabelecidas entre os diferentes pontos de vista, no contraste oferecido àqueles que nos procuram para a aquisição de pensamento crítico. A publicação de textos que refletem tal diversidade é mais um ganho para nosso curso, para nossa universidade, que aposta sempre no debate.

Neste Literatura brasileira em foco VIII - outras formas de escrita, reunimos textos de professores vinculados à Universidade do Estado do Rio de Janeiro. A começar pela autora convidada, Marília Rothier Cardoso (PUC-Rio), professora aposentada da UERJ, cujo texto utiliza-se do humor para encaminhar considerações técnico-estéticas e críticas sobre a poesia brasileira contemporânea; na sequência, Ana Chiara apresenta uma leitura do romance Machado (2016), de Silviano Santiago, a partir de diálogos crítico-ensaísticos; Ana Lucia Oliveira propõe uma introdução crítica à copiosa epistolografia de Antônio Vieira; Andréa Sirihal Werkema revê as funções e técnicas da crítica literária descritivo-analítica, utilizando-se da descrição do romance Iracema feita por Machado de Assis; Éverton Barbosa Correia reconstitui a persona literária de Eduardo Prado, "mais monarquista do que prosador, mais pesquisador do que escritor, mais ensaísta do que militante ativo"; Fátima Cristina Dias Rocha detém-se nos livros O conto zero e outras histórias (2016), de Sérgio Sant’Anna, e Pai, pai (2017), de João Silvério Trevisan, abordando-os 
como dois diferentes exemplos do autobiografismo contemporâneo; Giovanna Dealtry investiga como o poeta Manuel Bandeira construiu em sua poesia lugares de trânsito ou permanência, por onde observa a vida vazar pelos supostos limites entre público e privado; Italo Moriconi investiga os passos percorridos pela obra da escritora Hilda Hilst até a consagração; Leonardo Davino de Oliveira propõe a leitura comparada entre as canções "Alegria, alegria”, de Caetano Veloso, e "Pra não dizer que não falei das flores", de Geraldo Vandré, para analisar gestos de militância e desbunde dos anos 1960-70; e Marcus Vinicius Nogueira Soares traça um breve panorama dos diferentes momentos da escrita da crônica no Brasil, com intuito de assinalar o percurso histórico do gênero na imprensa brasileira entre 1836 e 1936. Juntos, esses textos constituem uma amostra singular da diversidade e profundidade dos temas tratados por alunos e professores da Especialização em Literatura Brasileira da UERJ.

Os organizadores do volume Literatura brasileira em foco VIII - outras formas de escrita agradecem ao Instituto de Letras da UERJ e a todos os professores e professoras que participam de nossa Especialização, e dedicam este livro e todo o trabalho aqui envolvido aos alunos e alunas do curso, que tornam tudo isso possível. 
Marília Rothier Cardoso

Reinvenções poéticas pelo humor 
Há alguns meses, fiz parte do grupo de convidados para um banquete em torno da poesia. Os anfitriões - poetas, performers e pesquisadores de poesia - recomendaram-nos ler poemas e preparar falas sobre nossas leituras. Este contraponto entre comida e palavras lembra a estratégia do filósofo Gilles Deleuze de discutir a "lógica do sentido", explorando a dualidade corpos/linguagem. Conforme a história da filosofia, os antigos serviram-se dos elementos materiais para instrumentalizar o pensamento, prenderam-se à profundidade, onde os corpos se transformam e se afetam uns aos outros: Heráclito formulou o conceito de tempo observando o movimento da água; já Parmênides inspirou-se na terra e no fogo como causa principal na constituição do cosmos. Numa etapa mais sofisticada do ato de conhecer, quando se desejou distinguir o mythos do logos, Platão empreendeu o movimento ascensional e determinou que os significados se prendessem às ideias transcendentes, de que os corpos do mundo não passavam de cópias. Por seu turno, os sofistas - em particular, os estoicos - empreenderam aventura mais arriscada, experimentaram a superfície como espaço da operação da doação de sentido. Trataram suas elucubrações como "acontecimentos", resultados de gestos deslizantes, na linha horizontal que limita, 
abaixo, os seres corpóreos, e acima, a linguagem, formada de extrasseres incorpóreos. Nessa linha estreita e instigante, é que Deleuze surpreende o "sentido", resultado paradoxal de quase-causas que, negando as operações da profundidade (designação e manifestação) e da altura (significação), afirmam o sentido. Para tornar contemporâneo esse legado epistemológico dos antigos, Deleuze evoca poetas modernos às voltas com as "séries da oralidade" - comer/falar. De um lado, traz Artaud, preso às profundezas do corpo, escrevendo como se mastigasse as palavras. De outro, considera Lewis Carroll, que trouxe suas personagens fantásticas para a superfície do espelho. Aí, não há devoração nem transformações. O nonsense da superfície constrói-se na reversibilidade das direções e na simultaneidade dos tempos.

Imagino que os jovens poetas, reunidos neste "banquete experimental", mesmo que não radicalizem sua relação com a tradição poética, nem se dediquem aos jogos de questionamento das significações estabelecidas, pratiquem os exercícios do humor, resistindo às agressões sombrias do presente. Vou-me arriscar propondo minha leitura de trechos escolhidos de alguns deles.

Interessado em escapar das convenções do senso comum e do bom senso, Lucas Matos também se dedica à invenção poética e performatiza a dualidade falar-comer: 
em pedaços

[...]

CONVIDEI UM PAR de amigos para o almoço

comprei berinjelas batatas

baroas para o purê pimentões

gengibre abóbora chegaram

enquanto eu ainda estava

na cozinha mãos de cebola e alho

ele trouxe um kiwi congelado

para suco ou sorvete os dois

ficaram na cozinha sentados

no chão ou debruçados na parede

conversando enquanto eu

terminava então fui tomar

banho depois comemos na sala

[...]

foi que ele lembrou

da história do avô de uma

amiga da amiga

que sem ter com

quem conversar telefonava

para serviços de atendimento

ao cliente para reclamar

de coisas como o aumento

do preço do pacote de pão

[...]

comemos bis e tentamos

tomar o suco de kiwi na hora

da sobremesa quando eles se

foram já estava escuro

e tinha muita louça para lavar (Matos, jun. 2017, pp. 29-30). 
Não se pode dizer que a amostra dos "pedaços" de poesia, tratando de comida e conversa, seja tão atraída pelas vísceras profundas que chegue a mastigar as palavras. No entanto, sem que tenha suprimido letras ou insistido em sons guturais, o leitor do poema é captado, inevitavelmente, por sua materialidade. $\mathrm{O}$ corte dos versos insiste no atropelo da sintaxe e separa sujeito de verbo, adjetivo de substantivo, verbo de complemento. Aqui, a aparente experiência de tratar o banal com a solenidade da arte desenvolve o procedimento ambíguo de desafiar a gramática, mesmo usando ordem direta e obedecendo aos regimes nominais e verbais. $\mathrm{O}$ coloquial mais rasteiro se complexifica em estranhamento, impedindo que o poema aconteça apenas oralmente. Sua inscrição na página torna-se obrigatória. O leitor é conduzido até quase a vertigem (o poema é longo) do fundamento material, onde os tipos se inscrevem na página, para as alturas da significação, que os grupos de letras produzem. Em voz alta ou silenciosamente, a leitura exige saltos constantes, tornando inviável a suposta tranquilidade de uma conversa durante o almoço e demonstrando, na prática, a impossibilidade de que as relações verbais se processem inconscientemente como a digestão. Assim, revela-se, tão sub-reptícia quanto perigosa, a distância entre o corpo e a linguagem, entre a designação e a expressão. O rigor cruel da construção do poema fica patente na justaposição dos "pedaços” de que se compõe: a conversa afável dos amigos que se visitam, trocando gentilezas, é desmentida pelo assunto de que tratam. A troca de mensagens, levando ou não a consequências positivas, só se dá em situações previstas pela lei ou pelos interesses comerciais. A escuta atenta que se espera, ao invés de uma tendência afetiva, vem de uma previsão mecânica num texto decorado por um profissional. Atento às tecnologias características do presente, Lucas Matos percebe que o humor negro independe de 
monstros violentos. Ao contrário, surge, veemente e necessário, nas circunstâncias mais comuns, nas frases mais diretas, completas e corriqueiras.

No mesmo volume 2 dos Cadernos do CEP, Ana Carolina Assis usa estratégias composicionais bem mais complicadas com o objetivo paralelo de experimentar a tensão entre os corpos e a linguagem. Com um título em feminino - "Mariana" - que tanto pode nomear uma menina ou uma mulher como um local no campo ou na cidade, vai traçando uma cena familiar e surreal. Seu exercício poético fascina e ameaça. É um poema “em pânico". E foi o próprio Murilo Mendes que garantiu: "o pânico é muitas vezes necessário" (Mendes, 2010, p. 37).

\section{Mariana}

a criança

olhos de gafanhoto

água às vezes deixa um cheiro de

bicho nas coisas

carne pouca pra tanto lodo

bicho - água que escorre dentro d'água

a garganta

groselha rala das lancheiras

caramelo viscoso de rio

surpresa crosta das cartilhas

estufado piso e farpa dos móveis

as coxas - malha puída de nova

que uma barba crespa

rasga

e carrega nos ombros 
parecem bombas a mãe dizia parecem bombas de sucção a mãe dizia os ralos regurgitando carne e atraso pros jantares devolvendo a gelatina das coisas exigindo dos tijolos o que eles não tinham parecem sangue do meu sangue a mãe dizia (Assis, jun. 2017, pp. 6-7).

O vocabulário escolhido para compor a cena remete, sem dúvida, à profundidade dos corpos. As frases - ora quebradas em versos muito curtos, ora encadeando-se em versos longos - indicam invasões, contaminações. Predominam elementos líquidos ou pastosos que levam ao apodrecimento, à decadência. $\mathrm{O}$ ambiente turvo contrasta com a (possível) vitalidade da personagem - "criança”. No entanto, seus objetos escolares ("lancheira", "cartilhas") estão à beira de deteriorar-se na umidade reinante. Até a proximidade entre os corpos humanos mostra-se agressiva: as "coxas", a "malha" rasgam-se em contato com a "barba crespa". Sílabas iniciadas por gutural espalham-se pelo poema, assim como as matérias viscosas ("caramelo", "gelatina", "sangue") se insinuam por entre os sólidos. Esse espaço, tanto quanto a criança que vive nele com sua família, enfrenta o perigo do atolamento ou da sucção. Em sua crueza, a vida é uma ameaça.

$\mathrm{O}$ atropelo das imagens, que compõem o movimento das cenas, evoca o não senso das entranhas, da profundidade. No entanto, o corte e a distribuição dos versos na página não desfiguram as expressões aí inscritas. Também, diferente do que se espera, as indicações de tempo, em conjunto, fogem a qualquer cronologia, por isso, subvertem o processo das evoluções ou involuções. Coincidem, inesperadamente, o tempo do apodrecimento das partes da casa com o tempo da rotina familiar - a ida para a escola, os "jantares" —, como se ações e paixões surgissem em ritmo de "devir louco". 
O contraste, evidente, entre os movimentos no espaço e o tempo das personagens parece deslocar o poema das indistinções profundas às singularidades deslizantes da superfície. Assim, poder-se-ia captar a instauração de efeitos paradoxais que resultam em humor. O pathos trágico reverte-se em apreensão crítica.

Trabalho artístico equivalente, onde as séries da oralidade comer/falar —, parecendo tendentes à predominância da primeira, acabam mostrando deslocamentos entre uma e outra, encontra-se em poema assinado por Rafael Zacca, no $1 .^{\circ}$ volume dos Cadernos do CEP:

\title{
tarda
}

Uma barca leva uma pedra

ou um sol de flores engastadas

em poeira

sobre a pele oleosa

\author{
um aceno \\ como sabão das crianças \\ em tardes \\ de primavera a primeira
}

apenas uma

pedra

que se abre

dura lembrança das crianças que abrem

cocos e lambuzam já não se sabe

se o queixo ou as mãos

pequenas. 
Amargo é retornar
a gordura à boca

mas não seriam

amargos

os poemas de

agora postos

sobre a mesa e as conversas

meladas

como amoras

na boca (Zacca, maio 2017, pp. 24-5).

Tão distante da coloquialidade cotidiana quanto a escrita de Ana Carolina, esta experiência artística também se produz em certo clima solene e desconfortável. Desenha frases que se aproximam da textura incômoda dos corpos em busca do prazer eventualmente possível na prática da poesia. Embora sem polarizar os dois espaços - o que se poderia tomar como a significação sublime da arte, em oposição à designação dos corpos com suas vísceras profundas -, o poema se desloca entre um e outro, a partir da perspectiva do tempo. O emprego de uma forma verbal como título constitui procedimento incomum e sugere uma leitura atenta ao que escapa às convenções. Sendo assim, a cronologia - dependente das significações estabelecidas - cede lugar à materialidade do vocábulo "tarda", desencadeador de assonâncias: as vogais abertas ("tarda", "barca", "leva”, "pedra”, "sol", "engastadas"), que, ao longo do texto, retornam em alternância com vogais fechadas e nasais. Paralelamente, as aliterações (em dentais, bilabiais e sibilantes) compõem uma imagem sonora potente, superposta às imagens visuais propostas pela articulação - marca- 
damente surrealista - entre os significados do vocabulário empregado. Parece que a superposição das imagens sonoras - reforçadas pela distribuição gráfica da página - às imagens plásticas opera o duplo movimento de descida das formas estéticas ideais e de subida dos sons e texturas pegajosas (oleosidade, "poeira", consistência "melada" que "lambuza"), instalando a escrita na superfície. Pode-se, então, perceber, na reiteração do signo "crianças" - com suas conotações de "jogo" e "brincadeira" -, um deslizamento, alegre e cruel, entre o gosto (amargo, gorduroso), que sobe das entranhas à boca, e as "lembranças", "poemas" e "conversas", lançados "sobre a mesa". Seguindo a orientação deleuziana, para além dos efeitos trágicos ou irônicos, esse deslizamento na superfície produz o humor paradoxal. Se os efeitos desse jogo intrincado "tardam", é porque se mostram extemporâneos.

Ainda no $1 .^{\circ}$ volume dos Cadernos do CEP, Maria Isabel Iorio inclui uma releitura - em homenagem? como paródia para descarte? num retorno desviante? - de um clássico drummondiano ${ }^{1}$ do humor modernista:

virilha

João era Teresa que era Raimundo

que era Maria que era Joaquim que era Lili

que não era ninguém.

1 QUADRILHA

João amava Teresa que amava Raimundo

que amava Maria que amava Joaquim que amava Lili que não amava ninguém.

João foi pra os Estados Unidos, Teresa para o convento,

Raimundo morreu de desastre, Maria ficou para tia,

Joaquim suicidou-se e Lili casou com J. Pinto Fernandes

que não tinha entrado na história (Drummond de Andrade, (1930) 1967, p. 69) 
João foi para os Estados Unidos, Teresa para as estatísticas, Raimundo morreu de pancada, Maria ficou para a fila, Joaquim suicidou-se e Lili ainda é chamada de J. Pinto Fernandes como toda essa gente que não entra na História (Iorio, maio 2017, p. 19).

Apresentando-se como estratégia experimental distante de "Mariana" e "tarda" - escritas de um humor fantástico, que investe contra o real histórico por meio de um tenso contraste crítico "virilha" tende a aproximar-se de "em pedaços", radicalizando o emprego do coloquial através da repetição em diferença de um texto antológico, que qualquer leitor é capaz de reconhecer. Se Drummond parodiava a lírica romântica, num gesto, que hoje nos soa como simples inversão, Maria Isabel Iorio é, possivelmente, mais séria e desabusada, pois homenageia o mestre subvertendo suas referências ético-sociais. Se, no contemporâneo, acirram-se as questões de gênero, etnia, identidade e pertencimento a uma nacionalidade, $o$ novo poema afirma que não se trata mais de uma "quadrilha", onde se troca de par, mas de uma virada mais complexa. O título "virilha" aponta para significados múltiplos: parte do corpo geralmente sexualizada, reversão sem objetivo definido, devir constante em lugar de metamorfose ou até mesmo (com grafia ligeiramente modificada) uma das combinações de sílabas que, a certa altura, nomearam a personagem de "Desenredo" de Guimarães Rosa, aquela que mudava de amores e se mostrava outra a cada parágrafo da estória. Enquanto as vanguardas exigiam liberdade de escolha e ampliação do conceito de arte, a violência do cotidiano atual, nos vários níveis de relações, exige que se flexibilizem os critérios de identificação e se reivindiquem serviços públicos e visibilidade para os habitantes das diferen- 
tes margens. Os traços irônicos, que eventualmente ainda restassem na "Quadrilha" moderna, foram "virados" no humor cruel, onde as histórias (estórias) se confundem com a "História".

$\mathrm{Na}$ Lógica do sentido, que me serviu de referência, buscam-se linhas de fuga à tradição do pensamento ocidental. Por isso mesmo, seu interesse se volta para o "humor", distinto da "ironia", trabalhada pela escrita dos filósofos canônicos. Em suas três versões - socrática, clássica e romântica - a "ironia” volta-se para as alturas transcendentes (em contraponto à profundidade dos corpos), apegada, em cada período, a uma das dimensões da proposição: significação, designação e manifestação. Escapa a esta linhagem o "sábio estoico", que empreende a "dupla destituição da altura e da profundidade em proveito da superfície". "[...] Mais tarde e em outro contexto", pode-se acompanhar a trajetória do Zen "-contra as profundidades bramânicas e as altitudes búdicas. Os célebres problemas-provas, as perguntas-respostas, os koan, demonstram o absurdo das significações, mostram o não-senso das designações" (Deleuze, 1974, p. 139). Companheiro do sábio estoico e do cultor do Zen, o poeta especialmente desde Mallarmé - também empreende ascensões e descidas em direção à "superfície" da linguagem, onde acontece a "aventura do humor". 


\section{Referências}

ASSIS, Ana Carolina de. "Mariana". In CHACAL et al. Cadernos do CEP, v. 2 Rio de Janeiro, jun. 2017.

DELEUZE, Gilles. Lógica do sentido. Trad. Luiz Roberto Salinas Fortes. São Paulo: Perspectiva, 1974.

DRUMMONDDEANDRADE, Carlos. Obracompleta. Rio de Janeiro: Aguilar, 1967.

IORIO, Maria Isabel. "virilha”. In CHACAL et al. Cadernos do CEP, v. 1, Rio de Janeiro, maio 2017.

MATOS, Lucas. “em pedaços”. In CHACAL etal. Cadernos do CEP, v.2, Rio de Janeiro, jun. 2017.

MENDES, Murilo. In LIMA, Jorge de. A pintura em pânico; fotomontagens. Rio de Janeiro: Caixa Cultural, 2010.

ZACCA, Rafael. "tarda". In CHACAL et al. Cadernos do CEP, v. 1, Rio de Janeiro, maio 2017. 
Ana Chiara

Machado de Silviano (o texto de Estela para o pai) 
Repito-me: no palco, o mímico performa ações incompletas. Na plateia, o espectador completa-as. É o único modo de compreendê-las e de lhes emprestar significado.

(Silviano Santiago, p. 245)

Crianças, a guerra é um tiro a esmo. O que te confunde é a natureza do meu jogo (Rolling Stones)

Prepara

(O Show das Poderosas, Warner, Anitta, 2013).

\section{Vibrando em modo avião:}

Tudo é vagina. É disso que se trata. Da/do racha absurda/o. Do corpo aberto. Da água escorrendo. Desvios. Folhas úmidas. Refolhos. Dobras. Rosas roxas. Escuras de sangue pisado. Garganta profunda. Açaí. Água forte a Bandeira. Dali brotam as leituras rasuradas, em golfadas: a vida, a água viva, a origem do mundo de Courbet. Gorgomilos inflamados. Gritos presos nas gargantas das Capitus, Estelas, Carolinas. 
No final de Yayá Garcia até hoje me espanta o diálogo entre pai e filha.
Que pedia agora ao pai? Pouca e muita cousa; pedia que a acompanhasse, que cessasse a vida de dependência e servili- dade em que vivera até ali; era um modo de a respeitar e res- peitar-se. O pai escutava-a atônito: - Tu chegaste a amá-lo! Exclamou ele. Não o aborrecias? Amaram-se? E só agora sei... Bem digo eu; tu és uma fera.[...] (Assis, 1977, p. 508).

Tu és uma fera! Que se esqueçam os acontecimentos narrativos, as referências da história. A exclamação do pai reverbera na memória. Estela sai das sombras onde se perde no romance, uma heroína que renuncia ao amor para aparecer como "fera", algo irreconhecível aos olhos do pai. Um enclave narrativo. Um ato falho do mímico misógino.

Esta leitura vibra em modo avião. Medo. É o estalo de um tiro a esmo. Uma bala perdida. Um furo numa barriga. Um parto monstruoso. É deste lugar que sai o modo de ler. Da loca, do buraco de uma mulher como um bebê ainda sujo e ferido a bala. Ele irá morrer. A mulher presta atenção às mulheres como o carrapato atraído pelo ácido butírico. Seu modo de ler se asfixia num universo de sombras e rasuras. Portas estreitas por onde saíram Capitus, Estelas, Carolinas. Ela se enfia pela porta estreita da sororidade e reivindica alguma atenção para as mulheres que se esgueiram nas sombras onde $o$ amor é devoção entre homens, onde impera a amizade intergêneros. Ela está uma fera.

Esta leitura é uma boca aberta, um rasgo, uma ferida, uma fenda e um vagido, quer livrar-se da servilidade: ela quer libertar o pai. 


\section{Dar um corpo. Que corpo?}

Em 2014, Silviano Santiago lança o livro Mil Rosas Roubadas, tributário de uma longa amizade, em que o futuro "biografado" - o autor/narrador - teve de tomar o assento de seu biógrafo Ezequiel Neves (o "Zeca") que morreu sem ter cumprido uma tarefa. Livro de amor e saudade. Livro de desejo incontentado. Livro de um sobrevivente. De um viúvo. Em entrevista concedida, Silviano Santiago, para se opor ao retratismo biográfico, declarou - "uma autêntica biografia da vida interior".

A figura do sobrevivente paira também no livro seguinte sobre Machado de Assis. Deu-se, portanto, na arte o encontro de dois viúvos, dois sobreviventes. Uma viuvez de amigo (Silviano Santiago), outra viuvez de esposo (Machado de Assis). Em 2017, o escritor, crítico e professor mineiro lançou Machado, mais uma de suas articulações ensaísticas sobre vida e ficção romance, em que recorta um período difícil e dissolvente da vida do monstro intelectual que foi o autor fundador da Academia Brasileira de Letras e no qual compõe painel memorialista da vida da medicina homeopática, da vida da cidade do Rio de Janeiro e da vida da criação como doença.

Neste mapa ampliado de uma vida, cobrindo tantos aspectos, a criação pode ser vista travestida em "pequenas ausências", eufemismo para as crises epiléticas do patrono das letras, permitindo uma leitura delas em relação com os bastidores da criação do artista. Deste modo, é pela dobra (doença/criação) que Santiago costura o lugar de anterioridade, poço escuro dos afetos, dos fantasmas, a "lousa mágica do inconsciente" (como Santiago gosta de se referir) do que se capta não pelo pensamento, mas pela vida sensível, pelas marcas impressas e indeléveis dos fluxos do exterior e interior, pelos estados do corpo. Aonde iria o ar composto, o pudor, o trato civil de 
presidente da Academia quando à sua revelia tudo se contraía e ato contínuo se distendia? Aonde? A que lugar secreto, lugar do crime da criação, onde o escritor caía quando o corpo e a mente lhe fugiam ao controle. Um espasmo e um pasmo. Uma baba que entorna. Um curvar o pescoço que põe a vida de viés. $\mathrm{O}$ ataque força que o olho se desloque para dentro em êxtase. Essa "ausência" poderia ser uma destinação ou uma danação para aquele que escreve? Onde estaria o homem quando seu corpo estivesse entregue à "fera" que se esconde em cada um? Este não-lugar-este útero? "O camarim é semelhante a um poço profundo não armazena água, mas tinta negra” (Santiago, 2017, p. 263).

Santiago aproxima o ataque epilético cujo eufemismo usado por Machado de Assis em sua correspondência também podia ser a expressão "pecado original" à cura, por meio da arte a partir das possibilidades de sentido que apontavam para as convulsões: "De mim, vou bem, apenas com os achaques da velhice, mas suportando sem novidade o pecado original" (Santiago, 2017, p. 268). Eis os desdobramentos capturados pelo biógrafo:

Poucas semanas depois de ter escrito a carta em que o pecado original metaforiza o corpo epilético para em seguida o desmetaforizar recorrendo aos remédios receitados pelo médico que, se não trazem a cura, trazem o controle da doença, Machado de Assis retorna ao tópico. Desta feita, associa o controle da epilepsia (ou do pecado original para continuar no campo semântico da metáfora) à função primordial da arte para ele, tese que Mario de Alencar endossa. Este é ainda o destinatário da carta escrita por Machado. Copio: 'Também eu tenho desses estados de alma, e cá os venço como posso. A arte é remédio e o melhor deles.' (p. 268) 
Cura ou veneno? Ataque, achaque, convulsão, gozo, Santiago tem a generosidade de devolver o corpo aos escritores reprimidos. Foi assim na cena criada com Graciliano, cuja ereção na praia corresponde ao título à desrepressão do corpo um dos motivos do romance Em Liberdade (1981). Aconteceu assim com Machado de Assis, personagem do romance Machado em suas "ausências" tão próximas do estado de convulsão erótica. Santiago resgata - para o leitor - o corpo vulnerabilizado/erotizado de Machado em convulsões epiléticas, assim como Didi-Huberman (2015) leu o movimento convulsivo dos corpos das histéricas, em suas performances teatrais para Chacort, e como Warburg fez com o das bacantes. Santiago (2017, p. 269) nos ensina que a beleza convulsiva da arte se conquista desde os bastidores de um corpo entregue a si mesmo, um corpo acéfalo, o corpo da fera:

Entre a alopatia e a homeopatia, entre o dr. Miguel e o dr. Tomás, o vocábulo "remédio" sai, de repente, do campo estreito das cartas trocadas naqueles meses e da medicina a fim de se adentrar pela definição do que seja a atividade artística para o escritor epiléptico, ou seja, a função da arte no processo de criação da beleza convulsiva.

\section{A Ferocidade das Fêmeas}

Elas [as onças] sabem que sou do povo delas. Estou onçando, estou virada na Maria Maria. Estou chegando minha pata devagarinho no peito do Mestre, do pai das letras brasileiras. Eu tava com as unhas... [...] Aí eu tinha uma câimbra no corpo todo, sacudindo; dei acesso (Ana Chiara com Guimarães Rosa).

Em 2017, Santiago publica Genealogia da Ferocidade, livro em que faz uma leitura "desconstrutora" da recepção da obra Grande Sertão: Veredas, de Guimarães Rosa. Esse livro é a "bioescrita" de um livro - como antes o crítico tinha se ocupado de Macunaíma - 
recorde-se o artigo de Nas malhas da letra (ensaios), de 1989, quando fez um apanhado de como o livro foi entendido pela crítica. No caso de Grande Sertão, uma recepção crítica que tentou domesticar, segundo Santiago, por leituras comparativas, o caráter monstruoso (a palavra vem do latim monstrum, "sinal do que está por vir, presságio", ligado ao verbo monere, "avisar, advertir”). Em sua leitura, numa direção diversa, o crítico deseja recuperar o nervo do processo de hibridação, em Meu tio o Iauraetê, conto de Guimarães Rosa, de um imaginário feito de algo de humano, mas também da ordem da animalidade, do corpo viril vivo, pulsátil desejante de Riobaldo/Reinaldo e do corpo macho/feminino de Diadorim morto, tornado larva luminosa, ninfa, corpo de formas arcaicas, sobreviventes também como o enclave histórico, geográfico, ambiental do Liso do Sussuarão.

Esta leitura está tendo um ataque epilético, um chilique, um "me segura que vou dar um troço", está intoxicada e procura nelas um nexo, um elo entre a figura da mulher nestes livros - suas sombras, sua ausência - e a da fera, da forma inconsútil de uma larva. Esta leitura é uma "ramificação sanguínea" da fera riscada nos livros de Machado. É parente da onça Maria Maria, do meu tio o Iauaretê. Esta leitura quer onçar. Nela a mulher é o liso do Sussuarão. É um locus tenens. Um enclave arcaico e monstruoso. Um mapa em disseminação. É dirigida a pai. Pai eu te escrevo das sombras, de um campo destroços. Pai, por que me abandonaste? (ana chiara)

\section{A mulher à sombra}

No conto Todas as coisas à sua vez (Abecedário) de 2003, do livro Histórias mal contadas (2005) de Silviano Santiago, "homenagem ao notável escritor" Graciliano Ramos pelo aniversário de cinquenta 
anos de sua morte, escrito ao estilo "graciliano" por Silviano Santiago que tão bem soubera usá-lo no livro Em liberdade (1981): leio um comentário ou nota com referência à mulher na obra de Machado de Assis,

A mulher se esconde na sombra. Por que evita a luz? Por que não se desnuda? Por que nunca se dá a conhecer? Por que é segredo? //A mulher é Maia. Sua arma mortífera é o pudor. // Machado desvendou o mistério - o segredo da mulher. Só não passou a fórmula a nós, homens (Santiago, 2005, p. 120).

Mas haveria este mistério? Trata-se obviamente de uma pergunta lançada ao lugar comum masculino, reproduzido pelo escritor-personagem Graciliano. Difícil que - se houvesse ou se houver mistério - Machado o tivesse "desvendado", de temperamento misógino creio que o circundou e o recobriu com mais camadas de desconfiança ou, hipótese provável, reafirmou o mito do mistério como forma de afastamento e desconfiança. Por que este mistério teria uma "fórmula"? Por que interessa ao escritor Machado recobrir a mulher com camadas de sombras, como rasuras?

***

Em Walter Benjamin pode-se ler:

Ou seja, em sua conclusão, a criação torna a parir o criador. Não segundo a sua feminilidade, na qual ela foi concebida, mas no seu elemento masculino. Bem-aventurado, o criador ultrapassa a natureza: pois esta existência que ele recebeu, pela primeira vez, das profundezas escuras do útero materno, terá de agradecê-la agora a um reino mais claro. A sua terra natal não é o lugar onde nasceu, mas, sim, ele vem ao mundo onde é a sua terra natal. É o primogênito masculino da obra, que foi por ele concebida. (1987, p. 277)

(Atétu, Benjamin? Atribuindo à mulher o lugar da natureza? Pois eu proponho uma leitura como reação uterina. O lugar escuro do útero, 
sob ação das revoltosas erínias, estes elementos de feminilidade arcaica reivindicamafigura doquenão está. Figura quesevarreu para as sombras. Como a personagem de Machado de Assis em Yayá Garcia, Estela, minha leitura filha do romance Machado de Silviano, quer libertar o pai da melancolia e da servilidade à razão iluminista, libertá-lo das regras de civilidade da Academia Brasileira de Letras, quer libertá-lo de sua misoginia, de seu medo da mulher. Quer libertá-lo da admiração bem comportada (e desconfiada) por tantas personagens-femininas que retratou sob os véus do mistério, do enigma, da desconfiança.)

No romance Machado, persiste a imagem da mulher na sombra, da mulher à sombra. Santiago nos deixa frente a frente a isso, por meio da estratégia de pôr em evidência um sistema de rasuras ficcionais, como se verá na sequência, envolvendo o rascunho do livro Memorial de Aires, corroborado por trechos da correspondência entre o escritor do Cosme Velho e seu pupilo Mario de Alencar. Estas rasuras vão dar a medida do clima de desconfiança com que é tratada a mulher - vamos conceder: àquele tempo - através também de um jogo narrativo em que os nomes femininos vão se riscando, vão se metamorfoseando nas figuras de Carmelita, Carmo, Fidélia, Maia, Pandora, Maria, Carolina - este último o nome interdito ficará para sempre a mulher atrás do homem notável.

(Ele a jogou no túmulo e a cercou de flores, para ser resgatada por Silviano no rosto da mulher do povo - a sem nome. A da beleza convulsiva) ana chiara.

Na narrativa do romance, o capítulo "VII: Ressurreição dos Mortos", Silviano Santiago deixa ver que o tratamento dado à mulher na obra de Machado é marcado pela desconfiança dos personagens 
masculinos através de uma metafórica da construção civil bastante peculiar ao homem versus metafórica na qual a mulher será o elemento secundário. Se o homem é um monte de "pedras soltas", a mulher, cimento que o cola, tem "trejeitos camaleônicos". Na verdade, essa parece ser a ótica de Machado de Assis e não só de seus personagens homens. Silviano Santiago (2017, p. 247) é cuidadoso:

A reflexão íntima do protagonista masculino de Machado de Assis é produto das pedras soltas do seu temperamento e, ao se endereçar às incertezas do amor, tem seu ponto de partida nas primeiras tentativas de escrever literatura. O olhar doente e torto do apaixonado ganha então adjetivo. É de ciumento.

Preciso acompanhar a extensa digressão de Silviano Santiago (2017, p. 258), referindo-se ao processo de rasuras de Memorial de Aires: "Lúcia Miguel Pereira se refere às hesitações e correções que traduzem a insegurança do romancista (Machado) quanto ao nome próprio a ser dado às duas protagonistas femininas - a velha dona Carmo e a jovem viúva Fidélia”. Continua seguindo palavra por palavra Lucia Miguel Pereira: "[...] as trocas de nome entre D. Carmo e Fidélia são frequentíssimas, são mesmo quase a regra. Em 393 das 468 páginas do manuscrito existem 167 dessas trocas; cada vez pensava numa, a figura da outra lhe acudia ao espírito, como se as confundisse. Confundi-las-ia também o coração?”. Santiago (p. 259) conclui: "O manuscrito quer confundir dona Carmo e Fidélia”. Avança o raciocínio: “(Machado) perde o controle no julgamento racional sobre as amadas viúvas da sua vida?". Segue Silviano Santiago (p. 260): "O enigma proposto pelo exame do copião de Memorial de Aires e pelo conhecimento da vida do romancista do chalé do Cosme Velho diz que as duas são uma só." As duas, prossegue Santiago (p. 261), seriam na verdade três, diz num parágrafo curto: "Essa figura (uma figura feminina única) seria o côncavo da vida 
amorosa, sua raiz, de onde brota uma e outra protagonista”. Depois completa a imagem: "Coexistem num único e terceiro nome próprio, que tem de ser rasurado, borrado pelo escritor, para que dois outros e diferentes nomes próprios emerjam da mancha negra da escrita e existam como protagonistas singulares do Memorial de Aires".

Tomar uma pela outra, rasura todas. A mancha côncava me remete à forma útero, pois não foi de lá que começamos esta leitura? Por que trocar uma por outra? Todas se confundem no seu coração? (ana chiara)

O sistema de rasuras também é observado por Mario de Alencar, em torno do nome "riscado" e substituído de Carolina, a esposa morta, conforme o narrador (p. 266) explicita: “O mímico não pode deixar de ser cauteloso e precavido e é por isso que, em paralelo à indiscrição do septuagenário, existe um delicado sistema de rasuras":

Iluminado pela descoberta, Mario se reconhece leitor privilegiado pelo mestre e, ao mesmo tempo e convenientemente, se resguarda e se isola dos futuros leitores do romance. Só ele pode deter e detém a chave para entrar pela porta da quarta dimensão, cuja chave é de uso exclusivo de Carolina (Santiago, 2017, p. 265).

Mario se torna o leitor primeiro e confidente de Machado, lugar antes ocupado por Carolina. Machado o seduz com a promessa de um segredo: "Aproveito a ocasião para lhe recomendar muito que, a respeito do modelo Carmo, nada confie a ninguém; fica entre nós dois" (p. 265).

(Ai, Jesus! "Entre nós dois" é quase uma frase enamorada, muito mais quando o nome rasurado neste lugar desconfortável é o de sua esposa morta) ana chiara. 
Derrida, cujos textos foram difundidos nos cursos de Silviano Santiago na PUC-Rio, escreve sobre Babel dizendo-o um nome próprio que se torna inatingível. Este é o circuito produtor do signo, uma cadeia de substituições da "coisa" criando uma ilusão de presença. "Babel: antes de tudo um nome próprio, seja. Mas quando dizemos Babel, hoje, sabemos o que nomeamos?” (Derrida, 2002, p. 11). Ao substituirmos Babel por um nome de mulher, sabemos o que nomeamos? O nome Carolina, lido por Mario no segredo da rasura, uma torre erguida entre os dois homens, dois escritores, dois temperamentos neuróticos dados a achaques e "ausências": Machado de Assis e Mario de Alencar.

A dobra do significante, da letra, este MMdeA num ringue cheio de pudor, celebra a união dos dois escritores nos ataques convulsivos. "Estes dois..." diria Nelson Rodrigues. A mulher de Mario Alencar fica apartada na casa grande. Sozinha. O pupilo vai para a casa próxima à do Mestre. Unidos na doença, são nevróticos/neuróticos, os excessos de calor ou frio provocam neles reações físicas incontroláveis. São térmicos, como na releitura de Grande Sertão:Veredas, Santiago aponta a respeito dos amores entre Riobaldo e Reinaldo/ Diadorim que também opera por rasura ou troca: “[...] Agora, destino da gente, o senhor veja: eu trouxe pedra de topázio para dar a Diadorim; ficou sendo pra Otacília, por mimo; e hoje ela se possui é em mão de minha mulher!” (Rosa apud Santiago, 2017, p. 85).

(Eu hein, Rosa...Esta história está mal contada, contada pela metade. Ou sou eu que entro em delírios de leitora frenética e misturo as cartas, nossas cartas? Não me chama de louca que te acuso de gaslighting) ana chiara. 
Santiago ainda neste capítulo do livro Machado traz à baila o caso da bacia: anotação de Machado junto ao relato das "ausências". Aos leitores de Machado, ele arrisca: “[...] a anotação, que apenas me direciona a significações subjetivas e aleatórias”(p. 279). Significações que dirá adiante conformarem um "complexo sistema de alusões" (p. 280). Vai buscá-las em Esaú e Jacó numa bacia de esmolas para referi-las ao caráter desonesto do capitalista brasileiro/do irmão das almas. Impressiona-me o termo bacia, este lugar alquímico e gestacional. É pelas rachaduras digressivas que Machado escreve com o corpo feminino, conforme seu biógrafo (p. 281) anota: "corte, abertura e digressão, se somados, são a forma mais autêntica e corajosa de Machado interromper [...]”. Eu abrevio a metáfora por minha conta: ao interromper a narrativa linear tradicional masculina, Machado usa sua bacia, o outro lado de sua máscara de Janus. Natividade corpo materno de Machado - , no romance, vai parir três monstros: Pedro e Paulo, os fracos e indecisos, e Nóbrega, o ladino e corrupto irmão das Almas, este ser de rapina. Por sua intromissão na narrativa, de sua bacia, saíram os abortados: os homens fracos.

\section{A mulher do povo}

Mas, avanço, em busca da mulher que ampara o homem ao longo do livro de Santiago, imersa nas sombras, sem se deixar ver. No capítulo "Transfiguração", personagens homens se apaixonam por uma tela que dá nome ao capítulo, a tela "A mulher do povo", de Rafael Sanzio que será admirada por Sthendal, Machado de Assis e por outros. Silviano Santiago nos conduzirá pacientemente por essas leituras. Será o narrador do livro Machado, ou seja, Santiago na função autor/narrador que tirará das sombras a figura da mulher do povo num revirão gestáltico. 
Se, no romance Machado, as mulheres são aludidas, mantidas à distância, pelo olhar do narrador que capta a real situação da mulher na vida do Rio de Janeiro àquela época, será este olhar solidário contemporâneo que fará o movimento transfigurador da tela de Rafael alterando o sistema viciado da figura/fundo. Tudo neste capítulo tende às inversões. É na colina do Janículo, em meio à paisagem modesta, que Stendhal verá o quadro. O cruzamento de olhares masculinos (Sthendal, Joaquim Nabuco, Magalhães de Azeredo, Benito Pardo, Anton Raphael Mengs) sobre o quadro é sequencialmente recuperado, as leituras são intricadas e cheias de reviravoltas, sendo impossível aqui seguir passo a passo as descobertas de Santiago atribuídas a Machado. Seleciono, do capítulo, a menção do narrador a uma figura feminina do quadro de Rafael: "à frente da cena dramática, destaca-se uma mulher ajoelhada, de perfil. Figura enigmática, sua cabeça está virada para os apóstolos. Seria Pandora?” (Santiago, 2017, p. 404). Por obra de seu lado sismógrafo, Santiago vai perceber novas acomodações de figuras. É a dança da menina dos olhos em busca do que olhar, nos livros em que pesquisa, que revela o modelo da mulher magnífica do quadro da Transfiguração?

Trata-se de uma anônima. Uma mulher do povo que Santiago (2017, p. 411) repara ter sido reencontrada em esboços, desenhos. "Num segundo momento o crítico (Mengs) compara a figura da Virgem, representada na Sagrada Família, tela a óleo, ao desenho a lápis de uma mulher do povo, para contrastá-los”. Esse desenho não está exposto, foi Santiago que o tira dos arquivos do Museu do Louvre em suas leituras. Rafael, talvez apaixonado por uma mulher do povo, teve de torná-la sublime no quadro da Sagrada Família. Outro modo de rasura. Mas a este movimento, Silviano Santiago faz uma torção quando do quadro nos revela como a partilhar o punctum a real condição da modelo para a família. É a mulher do povo, a anô- 
nima, essa que será pintada por Rafael e que atiçará a curiosidade dos leitores atuais deste romance. Silviano Santiago a retira do plano de fundo para o plano de frente. Ela deverá a partir disso atiçar uma nova atitude dos expectadores do quadro, dos leitores de Machado, pelo olhar de Santiago. Ela é a nova Estela. A nova estrela. É fera.

É belíssimo o movimento!

(Respiro fundo. Abandono o livro, usei-o como quis. Nele, a lembrança de Estela ressurge com a mulher do povo. Está gloriosa! Ela diz: Pai, não se amofine, já estou indo libertá-lo de seus medos, de sua forma, de sua fórmula, de suas metáforas militares, suas parábolas, sua cauterização erótica, vamos cometer o incesto da arte, este pecado original, esta arrogância convulsiva, esta epilepsia, esta histeria, esta "gravidez psicológica". Vou te parir de novo em homem lavar, coisa fugidia, meio mole, indescritível, escuro como uma enguia, coisa escorrendo de dentro do meu corpo....vou te dar um buraco. Aquilo: uma racha. Uma fenda. Uma abertura a mais para te alimentar e te fazer feliz...Prepara!) ana chiara. 


\section{Referências}

ASSIS, Machado. "Yayá Garcia". Obra Completa, de Machado de Assis, vol. I, Rio de Janeiro: Nova Aguilar, 1994.

BENJAMIN, Walter. Rua de mão única. Trad. Rubens Rodrigues Torres Filho e José Carlos Martins Barbosa. São Paulo: Brasiliense, 1987, p. 277.

DERRIDA Jacques. Torre de Babel. Belo Horizonte: UFMG, 2002.

DIDI-HUBERMANN, Georges. Invenção da histeria: Charcot e a iconografia fotográfica da Salpêtrière. Trad. Vera Ribeiro. Rio de Janeiro: Editora Contraponto, 2015.

SANTIAGO, Silviano. Histórias Mal Contadas (contos). Rio de Janeiro: Rocco ed, 2005.

. Em Liberdade (romance). Rio de Janeiro: Rocco ed, 1981.

. Nas malhas da letra. Rio de janeiro: Rocco ed, 1989.

Anônimos (contos). Rio de Janeiro: Rocco ed, 2010.

. Mil Rosas Roubadas. São Paulo: Companhia das Letras, 2014.

. Machado (romance). São Paulo: Companhia das Letras, 2017.

Genealogia da ferocidade. Pernambuco: Companhia Editora de Pernambuco, 2017. 
Ana Lúcia Machado de Oliveira

\section{"Até os penhascos duros respondem":1 Breve introdução à epistolografia de Antônio Vieira}

1 Trata-se de fragmento de carta endereçada à nobreza de Portugal, de 31 de julho de 1694, em que se lê: "É cousa tão natural o responder, que até os penhascos duros respondem, e para as vozes têm ecos. Pelo contrário é tão grande violência não responder, que aos que nasceram mudos fez a natureza também surdos, porque se ouvissem, e não pudessem responder, rebentariam de dor" (VIEIRA, 2014, t. I, vol. IV, p. 499). 
As cartas de Vieira não são informais e não se podem ler como depósitos neutros de informações positivas sobre acontecimentos do século XVII. Seu eventual leitor as lerá mal ou parcialmente, se não observar que sua forma é modelada por categorias retórico-poéticas da preceptiva epistolar e teológico-políticas da doutrina católica da monarquia absolutista (Hansen, 2003, pp. 14-5).

Não pretendo aqui desenvolver um estudo aprofundado da epistolografia do jesuíta português Antônio Vieira, mas apenas levantar alguns pontos que funcionem como porta de acesso, para neófitos, a essa copiosa e relevante produção textual, constituída até o presente por cerca de 750 peças que ainda não mereceram atenção suficiente por parte da crítica. Como se sabe, esta foi uma prática letrada muito utilizada pelo inaciano no decurso de toda sua longa vida, desde a sua primeira missiva conhecida, a carta ânua dirigida em 1626 ao Geral da Companhia de Jesus em Roma, ${ }^{2}$ até a última, ditada dias antes de sua morte, em 1697, e igualmente endereçada ao Geral dos jesuítas. Além de sua troca epistolar com membros do clero, Vieira se correspondeu igualmente com figuras bastante influentes na vida

2 Para uma análise da carta ânua vieiriana, consultar: Oliveira, 2008, pp. 137-54. 
política e diplomática lusitana da segunda metade do século XVII, dentre as quais se incluem reis, membros da família real e da nobreza.

Importa destacar que essa vasta produção fornece indicações preciosas sobre o percurso biográfico do autor - lugares visitados, atividades realizadas, relações que manteve - e nos oferece ainda numerosas informações sobre o tempo em que viveu, segundo o próprio jesuíta afirma no final da vida, em carta a Francisco de Brito Freire: "Que novas darei de mim a Vossa Senhoria, depois de tantos anos, senão que ainda vivo? Parece que me guarda Deus para testemunha da variedade e mudança do mundo neste século, depois de ter corrido e visto tanta parte dele" (Vieira, 2014, tomo I, vol. IV, p. 445, grifos meus).

Antes de iniciar o exame específico das cartas vieirianas, é fundamental tecer breves considerações acerca da inserção desse gênero na longa tradição da ars dictaminis, a descrição medieval da arte de composição em prosa e, mais especificamente, da escrita de cartas, segundo uma prática ligada ao estudo da retórica, tal como foi sistematizada na Idade Média. Sabe-se que a carta também foi utilizada na Antiguidade, mas sem ganhar o estatuto de um gênero de discurso e, por isso, não foi tratada especificamente nas artes retóricas desse período. James Murphy, em sua relevante obra Rhetoric in the Middle Ages, nos informa que só no quarto século da era cristã iniciou-se uma discussão sobre a epistola, na obra Ars rhetorica, do romano Julius Victor, que a relaciona ao sermo, ou discurso informal, considerando-a um tipo de conversação entre pessoas ausentes (Murphy, 1990, p. 195). Para os propósitos deste trabalho, importa destacar sua distinção entre dois tipos de cartas: as negotiales, que tratam de temas de interesse geral, por isso admitem a dissertação, a erudição e os ornamentos, além de uma extensão maior; e as fami- 
liares, que abordam assuntos particulares, aplicando um estilo mais simples.

Segundo Murphy, o nascimento da ars dictaminis e seu estilo correlato, denominado cursus ou ritmo da prosa, está relacionado ao monge beneditino italiano Alberico de Monte Cassino, o primeiro a relacionar retórica e escrita de cartas num tratado formal sobre essa nova arte, no século XI, retomando as partes do discurso estudadas por Cícero e articulando-as à composição epistolar. Em suas obras Dictaminum radii (ou Flores rhetorici) e Breviarium de dictamine, o beneditino nos apresenta os elementos centrais da ars dictaminis: a relação da retórica com a escrita epistolar, a padronização das partes de uma carta, a ênfase nas seções introdutória e de saudação com a distinção entre níveis sociais dos destinatários, a inclusão de modelos de cartas e formas oficiais (cf. Murphy, 1990, p. 210).

Alguns anos depois, o centro da reflexão acerca desse gênero discursivo passou a ser a cidade italiana de Bolonha, em que vários autores desenvolveram trabalhos sobre essa arte que permaneceram modelares durante vários séculos. Dentre as primeiras teorizações sobre a composição de cartas, surgidas no século XII, se destaca a do denominado Anônimo de Bolonha, cujas Rationes dictandi datam do ano de 1135. Em tais regras, especifica-se a divisão mais habitual de uma carta em cinco partes: saudação, captação da benevolência, narração, petição e conclusão (Tin, 2005, pp. 83-101). Para ressaltar o grau de formalidade presente na codificação medieval do gênero, basta mencionar que, nessa obra, enumeram-se dezessete tipos de saudação, determinados pela relação estabelecida entre o remetente e o destinatário no âmbito das práticas sociais. Assim, há modelos de saudação adequada, por exemplo, entre senhores e súditos, súditos e senhores, eclesiásticos, senhores a subordinados culpáveis e até mesmo de filhos delinquentes aos pais. Deve-se destacar que, nesse 
pequeno tratado de cerca de trinta páginas, é precisamente a saudação que recebe o tratamento mais minucioso, o que evidencia o valor das relações de subordinação sempre reiteradas pelos diversos modos de saudar. ${ }^{3}$

A partir do século XIV, com a descoberta de volumes de epístolas de Cícero por Petrarca, ${ }^{4}$ houve uma nova floração da ars dictaminis, de que serão exemplares os trabalhos de Erasmo de Roterdã, Brevissima formula (1520), e de Justo Lípsio, Epistolica institutio (1590). Uma característica marcante nessas novas artes é o abandono de algumas formalidades exigidas na composição epistolar medieval, que passaram a ser consideradas excessivas, consoante nos indica Erasmo (apud Tin, 2005, pp. 118-9):

Quão ridículos são aqueles que todas as cartas em saudação, exórdio, narração e conclusão dividem, e pensam que nelas consiste toda arte. Nem sempre é necessário usá-las todas juntamente, nem com frequência inteiramente e, como nos discursos, muitos mudam, conforme o caso, os tempos, a necessidade, a ocasião.

Visto que o foco deste texto é apresentar a correspondência de autoria de Vieira, torna-se necessário tecer algumas considerações acerca do lugar da epistolografia no âmbito da ordem religiosa a que ele pertencia. Criada em um tempo de acelerada expansão ultramarina (1540), a Companhia de Jesus refletia, em seus componentes e em sua distribuição geográfica, uma espécie de globalização avant

3 Uma tradução em português dessa obra, bem como das artes epistolares de Erasmo e Justo Lipsio, pode ser encontrada em Tin, 2005.

4

Destaque-se aqui, de passagem, que tal descoberta está diretamente relacionada à grande voga de imitação clássica nesse período, que teve seu ápice no ciceronianismo do início do século XVI, já foi amplamente estudado por Marc Fumaroli, na primeira parte de sua relevante obra sobre a "idade da eloquência” (1980). 
la lettre que caracterizava aquela época: oriundos de vários países europeus, seus integrantes logo se espalharam por Itália, Irlanda, Portugal, Espanha, França, além de Ásia, África e América do Sul, onde novos membros, autóctones, começaram a ser admitidos. Para manter a unidade e a comunicação com o centro romano da Companhia, implantou-se um instrumento fundamental: a correspondência epistolar, "coluna vertebral do corpo inaciano", nas palavras de Sheila Hue (2006, p. 14). A esse respeito, importa mencionar que o fundador da Ordem, Inácio de Loyola é autor de uma monumental correspondência, constituída por cerca de sete mil cartas, algumas das quais bastante extensas e minuciosas. Loyola, estabeleceu uma espécie de "pacto epistolar" com políticos, reis, pensadores, artistas e eclesiásticos, sempre trocando conselhos, preceitos, reivindicações, discutindo sobre matérias diversas, defendendo os princípios e a legitimidade de sua Companhia em todos os continentes em que esta se estabeleceu (cf. Bettiol, 2008, p. 26). Em alguns de seus textos, o religioso espanhol discorria sobre o modo adequado de redigir cartas, conforme se lê no seguinte trecho de caráter metaepistolar:

La carta principal yo la escribo una vez, narrando las cosas que muestran edificación, y después, mirando y corrigiendo, haciendo cuenta que todos la han de ver, torno a escribir o hacer escribir otra vez, porque lo que se escribe es aún mucho mas de mirar que lo que se habla; porque la escritura queda, y da siempre testimonio, y no se pude así soldar ni glosar tan fácilmente como cuando hablamos (Loyola, 1975, p. 687).

Sabe-se que um dos objetivos básicos das cartas jesuíticas era o controle interno da missão pelos superiores da Ordem em Roma, que exigiam relatórios minuciosos sobre a rotina diária dos padres e informações sobre possíveis causas de desânimos e crises. Assim, nesse eficiente sistema de comunicação, missionários disseminados pelo globo enviavam missivas para Roma, as quais eram copiadas e 
distribuídas pelas missões de modo que todos soubessem o que se fazia nesses variados lugares. Outro objetivo, segundo Adolfo Hansen, era o reforço do entusiasmo catequético por meio da remessa das cartas para outras missões, em que eram lidas como edificação (cf. Hansen, 2005, p. 16). Em síntese, essa surpreendente rede de comunicação global em pleno século XVI constituía um poderoso instrumento de informação e de divulgação das atividades da Companhia de Jesus.

Inserindo-se na longa tradição medieval da ars dictaminis, ${ }^{5}$ essas cartas trouxeram a diferença de serem geralmente redigidas em tom um pouco mais coloquial, procurando uma comunicação mais direta, sem muitos artifícios de retórica ou citações eruditas, e aplicando, nas palavras de Adolfo Hansen (2005, p. 26), "um aptum ou decorum específico da imitação do oral". Adotado por Loyola e seus seguidores, o modelo ${ }^{6}$ da missiva como uma conversação entre amigos, e não como discurso elaborado, atraiu o público leitor do período, o que se evidencia pelo grande número de traduções e edições das cartas jesuíticas, ${ }^{7}$ que afirmavam o poder e a expansão da Igreja Católica em tempos de Contrarreforma, além de saciar a curiosidade dos leitores acerca das novidades dos novos mundos (cf. Hue, 2006, p. 18).

Embora tendo motivado, ao longo do tempo, o interesse de pesquisadores de diferentes áreas do conhecimento, a correspondência de Vieira ainda aguarda uma edição crítica à altura da sua

5 Para as diversas variações no estilo epistolar ao longo do século XVII, ver Beugnot, 1994, pp.187-204.

6 Para um exame da estrutural formal das cartas jesuíticas e de sua ligação com a tradição da ars dictaminis, consultar Pécora, 2001, pp. 17-68.

7 Uma análise das diversas edições das epístolas inacianas nos séculos XVI e XVII foi feita por Lima, 1983. 
riqueza e da sua importância para a investigação de questões históricas, teológicas e políticas do século XVII. Destaque-se que toda a vida portuguesa do período da Restauração aí se encontra fotografada: enredos diplomáticos e intrigas palacianas, primazias políticas e questões religiosas, problemas militares e navais. Além da diversidade de temas tratados nas cartas, deve-se enfatizar a grande variedade de lugares em que se encontrava o remetente, que escreveu de Dover, Paris, Haia, Barcelona, Liorne, Roma, Porto, Coimbra, Lisboa, Alcanede, Carcavelos, Bahia ou Maranhão. É meritório igualmente destacar o perfil de seus destinatários aqui apresentados, tendo em vista uma ordem decrescente de distribuição do corpus textual, entre eles, segundo nos informa Carlos Maduro (2013, p. 60): nobres e diplomatas, clérigos e religiosos, reis e príncipes e cartas jesuíticas. A esse respeito, o referido estudioso do epistolário vieiriano ressalta uma desproporção assinalável em favor dos destinatários nobres e diplomatas, o que o faz concluir:

[...] Vieira gostava de falar com os homens do mundo acerca das coisas do mesmo mundo, servindo-se da carta para estar a par do que havia de novo. Com efeito, o jesuíta falou de tudo um pouco, na mais genuína tradição da retórica epistolar clássica de uma conversa entre amigos ausentes (Maduro, 2013, p. 61).

No que se refere à publicação dessa correspondência, assinale-se que a editio princeps, incompleta e com um texto mutilado pela censura, principalmente nas cartas em que o epistológrafo se refere aos cristãos-novos e ao Santo Ofício da Inquisição, data de 1735, quando se editaram dois volumes, organizados pelo Conde da Ericeira e pelo padre Antonio dos Reis, e dedicados ao Inquisidor Geral; o terceiro foi dado ao prelo em 1746, compilado pelo padre Francisco Antonio Monteiro. No Prólogo dessa edição, justifica-se a ausência de qualquer critério na ordenação das cartas, a partir de um 
argumento baseado no método escolhido pelo próprio jesuíta para a organização de seu sermonário tendo em vista o prelo:

[...] não se ordenarão estas cartas pela ordem rigorosa, e cronológica, em que foram escritas [...], porque ainda que os sucessos da vida deste Autor se percebem melhor nesta forma, como ela vai observada em cada uma das correspondências que, segundo o estilo comum, vão separadas, se percebem melhor, sem interromper-se os motivos, e os sucessos. Também não as dividi por matérias, por não alterar a referida suposição; e porque a variedade é mais agradável pelas razões sólidas, que dá o nosso Autor na primeira parte dos seus Sermões, quando no Prólogo se justifica de os não repartir pelas matérias, nem pela ordem dos tempos, e festas do ano (Vieira, 1735, s. p.).

Em 1854 e 1855, uma nova edição ampliada do epistolário vieiriano, apresentando 511 cartas, compôs os volumes XVI a XIX das Obras completas. Mantinha-se a mesma ordenação da edição anterior, que seguia apenas a ordem em que os originais chegaram à oficina do impressor, e apresentava, inclusive, a mesma repetição de textos. Arrumando as cartas em ordem cronológica e, com isso, evitando o problema das repetições, a edição seguinte foi feita pela Empresa Literária Fluminense, em dois volumes sem data, supostamente no ano de 1877. Entre 1925 e 1928, foi lançada uma importante edição das cartas de Vieira, num total de 719, divididas em três volumes que foram organizados por João Lúcio de Azevedo. Consultando as publicações anteriores, cópias manuscritas das cartas e os originais autógrafos a que teve acesso, o historiador português buscou apresentar uma publicação "menos viciada de imperfeições”, segundo nos esclarece na introdução, "reduzindo ao paradigma mais recente $^{8}$ as diferentes ortografias de três séculos" (Azevedo, 1970, p. XIV).

8 Para uma crítica da modernização da ortografia e da pontuação, presentes na edição preparada por Lúcio de Azevedo, cf. Révah, 1947, pp. 255-70. 
Durante várias décadas, essa relevante edição serviu de fonte principal de consulta para leitores e estudiosos da obra missivista do jesuíta. Cabe mencionar que até mesmo algumas iniciativas editoriais referentes à epistolografia vieiriana não fizeram mais do que reimprimir os textos fixados e anotados por Azevedo. No final da década de 1990, a ensaísta portuguesa Maria Lucília Pires (1997, p. 21) nos alertou para o fato de que "o estudioso de hoje, bendizendo embora o trabalho emérito do ilustre vieirista que foi Lúcio de Azevedo, tem ainda mais aguda consciência das limitações de sua edição". Dentre estas, ressalta o fato de o editor ter seguido frequentemente o texto da primeira edição, publicada, como se sabe, "sob as restrições do aparelho censório então em vigor, em casos em que os textos originais eram relativamente acessíveis" (p. 21).

É relevante mencionar a recente tentativa de superar as citadas limitações da edição organizada por Lúcio de Azevedo, com a Obra completa do Padre Antônio Vieira, dirigida por Jose Eduardo Franco e Pedro Calafate, que perfaz trinta volumes. No âmbito dessa publicação portuguesa, realizada entre 2013 e 2014, o tomo correspondente à epistolografia do jesuíta compreendeu cinco volumes nos quais se apresentam 758 cartas, dispostas em sequência cronológica, além de alguns textos apócrifos e outros de tipologia vária. Coordenada por Carlos Maduro, a equipe de pesquisadores, na qual me incluo, reuniu cronologicamente não apenas os textos publicados nas edições anteriores, mas também completou algumas das missivas mutiladas na primeira edição, reuniu cartas dispersas em diferentes publicações, traduziu um conjunto epistolar escrito em latim, que Vieira enviou a superiores da Companhia de Jesus em Roma, e publicou textos inéditos encontrados na Torre do Tombo e no Arquivo da Casa de Cadaval. Mesmo não se tratando de uma edição crítica, essa publicação fixou os textos com base em um conjunto expressivo de 
textos autógrafos e, quando estes não estavam disponíveis, foi feito um confronto "com edições manuscritas que se mantiveram muito próximas e muito fiéis aos documentos autógrafos", segundo nos esclarece o coordenador (Maduro, 2013, p. 44).

Nesta breve apresentação do epistolário vieiriano, importa ainda mencionar a existência de cartas e outros documentos cuja autoria é duvidosa - apesar de sua atribuição a Vieira em sua transmissão ao longo do tempo -, os quais foram publicados no quinto volume do tomo dedicado à epistolografia na Obra completa (2014). Cabe destacar que neles se pode perceber o desdobramento de matérias e questões abordadas pelo jesuíta em suas diversas intervenções tanto orais quanto escritas, que foram reapropriadas por autores anônimos, seja para emular suas ideias e formulações, seja para desqualificar o inaciano, atribuindo-lhe falsos depoimentos. Em alguns casos, esses documentos nos fornecem bons exemplos do pensamento dos que se opunham ao jesuíta; especificamente em relação aos textos que versam sobre a Inquisição e o judaísmo, eles nos facultam uma melhor compreensão da gravidade dos embates teológicos e políticos de sua época. Observa-se igualmente que, por vezes, os autores que se propuseram a imitar Vieira buscaram fazê-lo a partir de sua fama como orador eloquente, engenhoso e muito versado nas Letras; por esse motivo, empregaram uma linguagem afetada ou obscura, que, paradoxalmente, os afastou de uma faceta fulcral do estilo epistolar vieiriano: sua "simplicidade elegante" (Hansen, 2003, p. 39).

Cito como exemplo a carta apócrifa endereçada "A Jerónimo Sarrapante", publicada na edição da obra completa de Vieira (Carta 729 , t. I, vol. V, 2014), que constitui um exemplo patente de como ele era criticado por seus inimigos não apenas de voz, mas também por meio de "papeluchos satíricos", na expressão de Lúcio de Azevedo (t. II, 2008, p. 16). Devido ao grande número de cópias encontradas nas 
coleções da época, evidencia-se que se tornou bem conhecido um desses textos, escrito em forma de carta, supostamente assinada por Jerônimo Corrêa Sarrapante," "conhecido mentecapto, alvo das assuadas populares" (p. 16). O alvo principal da crítica era a intromissão de Vieira nos assuntos políticos de seu tempo. O texto apócrifo mencionado constitui uma breve resposta a essa carta, supostamente atribuída a Vieira, mas na realidade feita "por menos hábil foliculário", na correta avaliação de Lúcio de Azevedo (p.17), que corrobora a dúvida presente em nota ao manuscrito consultado para a edição portuguesa de 2014:

Não julgo este papel sendo de Vieira pelo estilo ser muito alheio, quanto mais que não costumava responder às coisas que faziam quem dizia que tinha juízo, quanto mais a quem estava louco. (Vieira, 2014, tomo I, vol. V, p. 169).

No esclarecedor prefácio de sua edição das cartas vieirianas enviadas do Brasil, Adolfo Hansen nos oferece orientações valiosas para tentar reduzir o anacronismo quase inevitável na retomada desses textos seiscentistas na atualidade. Em primeiro lugar, em relação ao remetente, deve-se atentar para o fato de se tratar de uma enunciação configurada como "racionalidade não psicológica de um tipo composto por paixões e caracteres subordinados como necessidade à hierarquia" (Hansen, 2003, p. 21). Considerando que a posição de Vieira como carteador é, antes de tudo, a de um tipo religioso subordinado às diretivas da Companhia de Jesus, o crítico nos apresenta uma síntese pertinente das diferentes posições institucionais desem-

\footnotetext{
9 "Carta que Jerônimo Corrêa Sarrapante escreveu a Antônio Vieira, estando preso por louco, no hospital o dito Sarrapante". Maquinações de Antônio Vieira jesuíta, Ms. da Biblioteca Nacional Portuguesa, t. 6, p. 231. Outras cópias desse texto são encontradas em diferentes códices dessa biblioteca.
} 
penhadas pelo inaciano que estão relacionadas ao decoro que rege suas missivas e aos diferentes matizes retóricos nelas configurados:

Tipo que, noviço, padre, mestre de retórica, teólogo, privado e valido de reis, amigo de aristocratas, inimigo da Inquisição, Superior de missão catequética, defensor de índios, afrontador de colonos, diplomata, orador sacro, profeta, não é uma subjetividade burguesa definida como unicidade de sujeito civil dotada de direitos liberais. Na sua representação como remetente, os interesses da monarquia e da Companhia de Jesus convergem, constituindo-o como tipo dotado de um caráter ou éthos principal, prudência, [...] que lhe controla o humor colérico legível em afetos secundários como raiva, desgosto, decepção, amargura, ironia (Hansen, 2003, pp. 21-2).

Desse modo, na maioria das vezes, os variados temas tratados em suas cartas se articulam diretamente aos acontecimentos que marcaram o seu tempo, ao lugar específico em que o remetente se encontrava no ato da escrita ou ao reino de Portugal em termos gerais. Dentre esses temas, se destacam: a invasão da Bahia pelos holandeses, a negociação com a França para formar uma liga anti-Espanha, a negociação com a Holanda para tratar da restituição de Pernambuco, o emprego do capital judaico na criação de companhias de comércio, o combate ao cativeiro dos índios, as viagens missionárias no Maranhão e Grão Pará, o poder da Companhia de Jesus sobre os aldeamentos indígenas, o processo inquisitorial e a vida no cárcere do Santo Ofício, a crise da lavoura açucareira, a febre amarela, o contrabando de ouro e prata, os preços monopolistas, a corrupção dos mercadores, a miséria dos pobres e o quilombo de Palmares.

Para os interessados nos seus célebres sermões, a leitura das cartas redigidas pelo inaciano possibilita o acesso a informações relevantes acerca do processo de reelaboração de sua oratória sacra para publicação, em correspondência enviada da corte, onde organi- 
zou os primeiros tomos, e do Brasil, de onde os diferentes volumes de seu sermonário, seguiam na frota para Portugal, "entre o mascavado do açúcar ou fumo do tabaco" (Vieira, 2013, t. I, vol. IV, p. 476), encaminhando-se ao prelo. Leiamos alguns exemplos. Em carta de 1678 a Duarte Ribeiro Macedo, afirma:

Pergunta-me Vossa Senhoria em que estado vai a estampa dos meus sermões, e digo que caminha com pressa, e com a oficina, que é de João da Costa, o francês, posta neste Colégio, e não há dúvida que sairá muito correta. O segundo tomo já está acabado e entro pelo terceiro, mas não poderão sair na mesma forma porque alguns dos sermões são do tempo da guerra, e não quero que se ofendam esses senhores da que já escreveram lhes faziam as minhas exortações. Se Deus der vida, matéria tenho deste gênero para mais de doze tomos [...] (p. 168).

Um tema recorrente em relação a essa publicação, portanto, é a necessidade de trabalhar as anotações de que dispunha, referentes a cada pregação especifica, para transformá-las em texto publicável, como se lê na seguinte carta de 1689, endereçada a Sebastião de Matos e Sousa: "Vossa Mercê, pela mercê que faz aos meus borrões, me insta a que os dê à estampa, o que não pode ser sem os alimpar primeiro; e com a joeira não ser muito fina, tudo se me vai em alimpaduras" (p. 405). E mais, em carta de 1683 a Diogo Marchão Temudo: "é só o que me obriga a tomar nos meus anos um tão molesto trabalho, como o de pôr os borrões em estilo que se possam ler" (p. 300).

Em síntese, o exame das cartas vieirianas permite comprovar a grande contribuição da epistolografia de Antônio Vieira não só para o conhecimento mais aprofundado de seu sermonário como também de aspectos decisivos da história do século em que ele viveu, consoante nos indica Maria Lucília Pires (1997, pp. 24-5):

Se é certo que as cartas de Vieira nos dão a imagem de um homem apaixonado por várias causas, política (no seu sentido eti- 
mológico) é talvez a palavra que unifica os diversos objetos da sua paixão. $\mathrm{O}$ apaixonado empenhamento de Vieira nas questões políticas, expresso na ação e na escrita, unifica no seu pensamento o pendor pragmático e a utopia messiânica, ilumina as diversas facetas da sua vida.

Ao leitor, portanto, um convite para a leitura das cartas de Antônio Vieira, tão obscurecidas pelo sucesso obtido por seus sermões quanto iluminadoras de importantes facetas da vida e da obra do jesuíta. 


\section{Referências}

AZEVEDO, João L. de. História de Antônio Vieira. 2 t. São Paulo: Alameda, 2008.

"Introdução". In VIEIRA, Antonio. Cartas. Coordenadas e anotadas por J. Lúcio de Azevedo. Lisboa: Imprensa Nacional, 1997, vol. I, pp. IX-XVI.

BETTIOL, Maria Regina B. A escritura do intervalo: a poética epistolar de Antônio Vieira. São Leopoldo: Editora da Unisinos, 2008.

FUMAROLI, Marc. Lâge de léloquence: rhétorique et "res literaria" de la Renaissance au seuil de lépoque classique. Paris: Albin Michel, 1980.

HANSEN, João A. "A escrita da conversão". In CONSTIGAN, Lúcia H. (org.) Diálogos da conversão. Campinas: Editora da Unicamp, 2005.

. "Introdução". In VIEIRA, Antônio. Cartas do Brasil. Organização de João Adolfo Hansen. São Paulo: Hedra, 2003. pp. 7-74.

HUE, Sheila Moura. "Introdução". Primeiras cartas do Brasil: 15511555. Rio de Janeiro, Jorge Zahar, 2006.

LIMA, Durval P. de. "As cartas dos jesuítas". Separata da Revista da Biblioteca Nacional n. ${ }^{\circ}$ 1-2. Lisboa, 1983, pp. 215-43.

MADURO, Carlos. "Introdução geral à epistolografia". In VIEIRA, Antonio. Obra completa Padre Antonio Vieira. Dir. José Eduardo Franco e Pedro Calafate. Lisboa: Círculo de Leitores, 2013, t. I, vol. 1. 
MURPHY, James J. Rhetoric in the Middle Ages: A History of Rhetorical Theory from Saint Augustine to the Renaissance. 6 ed. Berkeley, Los Angeles e Londres: University of California Press, 1990.

OLIVEIRA, Ana L. de. "As diferentes versões da Carta ânua de Antônio Vieira”. Ideação, vol. 2, n. 20, pp. 137-54, Feira de Santana, jul./ dez. 2008.

PECORA, Alcir. “A arte das cartas jesuíticas no Brasil”. In Máquina de gêneros. São Paulo: EdUSP, 2001.

PIRES, Maria Lucília G. "A epistolografia de Vieira. Perspectivas de leitura”. In MENDES, M. V. et al. (orgs.) Vieira escritor. Lisboa: Cosmos, 1997, pp. 21-30.

RÉVAH, I. S. "Petite contribution à la future édition des lettres du Père Antonio Vieira”. In Bulletin des Etudes Portugaises et de l'Institut Français au Portugal, t. XI. Coimbra: Coimbra Editora, 1947, pp. 255-70.

TIN, Emerson. A arte de escrever cartas. Campinas: Editora da Unicamp, 2005.

VIEIRA, Antonio. Obra completa Padre Antonio Vieira. Dir. José Eduardo Franco e Pedro Calafate. Lisboa: Círculo de Leitores, 20132014, vol. 30 .

. Cartas. Coordenadas e anotadas por J. Lúcio de Azevedo.

Lisboa: Imprensa Nacional, 1997, vol. 3.

. Cartas do Pe. Antonio Vieira da Companhia de Jesus. Lisboa Ocidental: Oficina da Congregação do Oratório, 1735-1746, vol. 3. . Cartas do padre Antonio Vieira. Lisboa: J. M. C. SEABRA e T. Q. Antunes, 1854-1855, 4 t., vol 2. 
Andréa Sirihal Werkema

Crítica literária: descrição, recriação, análise 
Exercer a crítica, afigura-se a alguns que é uma fácil tarefa, como a outros parece igualmente fácil a tarefa do legislador; mas, para a representação literária, como para a representação política, é preciso ter alguma coisa mais que um simples desejo de falar à multidão.

Machado de Assis

Descrever, como sabemos, é representar, por palavras, escritas ou ditas, tudo aquilo que nos cerca: pessoas, lugares, objetos, estados de humor, sensações, sentimentos, personagens, filmes, livros, vislumbres, a natureza. Representamos ao tentar reconstruir qualquer desses referentes citados através de palavras - e reinstauramos, em nosso discurso, o referente descrito. Recriamos. Note-se que nesse movimento de recriação verbal de um "objeto" não estaria presente, à primeira vista, uma opinião, qualquer sentimento de partidarismo ou de gosto, de juízo. A descrição seria apenas reprodução, em outro registro, que não o substancial específico de cada objeto descrito reprodução, ou melhor, representação verbal. Mas, é claro, e aqui já entramos no âmbito que nos interessa mais de perto, que não descrevemos nunca de forma imparcial - seríamos capazes disso? -, e acredito que tal observação possa se estender, como sabem os nossos tempos, mesmo ao campo das ciências. 
Por seu turno, o relato das várias fases de uma experiência científica constituirá modelo elucidativo de descrição dinâmica. Estes exemplos apontam para a chamada descrição técnica, que se caracteriza pela precisão do vocabulário, exactidão matemática dos pormenores, linguagem basicamente denotativa, por isso mesmo distinta da descrição literária em que predominam a subjectividade, a intenção estética, a conotação. Parece metodologicamente útil manter esta distinção, não esquecendo, todavia, a necessidade de lhes esbater os contornos, como sugere Helena Buescu, ao considerar a posição de Nelson Goodman que se 'recusa a aceitar o tradicional contraste entre científico-objectivo-cognitivo, por um lado e, por outro, o artístico-subjectivo-emotivo'. De facto, não é raro encontrar fragmentos de uma e outra tanto em discursos de natureza intencionalmente literária, como em documentos com a marca de históricos ou científicos (Paz, http://edtl.fcsh.unl.pt/encyclopedia/descri$\mathrm{cao} /$, grifos do autor).

A própria escolha dos termos usados na descrição, por exemplo, a definição de cores, de texturas, de analogias etc. prende-se à indeterminação própria da subjetividade que descreve. Em outras palavras, toda descrição é adjetiva - e todo adjetivo carrega seu grau de imprecisão, por estar ligado a visões particulares de mundo.

Toda a descrição pressupõe a captação do perceptível e a selecção subjectiva dos pormenores que, individualizando o 'objeto', interessam ao emissor e pretendem realizar o horizonte de expectativa do receptor, ouvinte ou leitor. São pertinentes, neste sentido, as observações de Adam e Petitjean cit. por $\mathrm{H}$. Buescu (Incidências do Olhar): '[...] uma descrição é [...] sempre o produto de um acto rigoroso de selecção que implica necessariamente uma subjectividade enunciativa e isto por diversas razões: 1) Não nos apercebemos da totalidade do que é perceptível. 2) Não verbalizamos a totalidade daquilo de que nos apercebemos. 3) Descrevemos em função dos nossos conhecimentos (da língua e do mundo) e dos que consideramos partilhados pelo leitor. [...]' (Paz, http://edtl.fcsh.unl.pt/encyclope$\mathrm{dia} /$ descricao/). 
E não nos esqueçamos de que do outro lado de qualquer descrição há outra subjetividade, a do receptor, que, dependente da fidelidade descritiva do emissor, preenche qualquer lacuna perceptível com sua própria capacidade de imaginar e de criar analogias. A discussão é muito complexa, e não seria possível desenvolvê-la sem longo período de reflexão, e maior tempo ainda de discussão: veja-se que deixo de fora, propositadamente, o conceito de mimese, aqui oblíquo à discussão que liga descrição à crítica, já adianto. Anote-se, no entanto, que um exame mais demorado das questões pertinentes à descrição como etapa da análise teria que investigar uma aplicação do fazer mimético, enquanto representação, estática ou dinâmica. Mas o que proponho é um rápido comentário sobre a descrição enquanto um dos elementos fundamentais da crítica moderna de arte, e no meu caso de interesse, da crítica literária.

Para isso, gostaria de usar um exemplo da literatura brasileira. Gostaria de narrar um episódio de nossa crítica literária: em 1865, um autor brasileiro publicou um romance, e acrescentou a ele um posfácio no qual descrevia as etapas de gestação e finalmente de criação do livro - processo de escrita. Alguns meses depois, já no ano seguinte, 1866, um jovem crítico literário publicou em jornal do Rio de Janeiro uma resenha crítica do mesmo romance. Em tal resenha o crítico descrevia o romance, reconstruindo seu enredo, seus personagens principais, suas características peculiares de linguagem elementos que, somados, deixavam transparecer, segundo este leitor-crítico, o método de gestação e de criação do livro.

Trata-se de um exemplo interessante de passagem do trabalho do autor para o trabalho do crítico; e a relação entre esses dois escritores se dá através de descrições dinâmicas, de processos de escrita, e também de descrições estáticas, de pormenores constituintes do livro em questão, já em sua forma acabada. O processo de reco- 
nhecimento entre quem descreve e quem lê a descrição, portanto, se dá em níveis diferentes: um autor escreve um livro e descreve o processo da escrita em seu paratexto, o posfácio; um crítico literário lê o livro e o descreve, e, por trás do enunciado, julga vislumbrar o mesmo processo de escrita, ratificando o que dissera o autor; por fim, nós leitores comuns, lemos o livro, lemos a resenha crítica, e comparamos as descrições propostas adicionando pormenores que nos dizem respeito e concordando ou não com as descrições dos dois escritores. É nesse jogo de subjetividades diversas que se faz possível aquilo que chamamos juízo, ou julgamento de valor da obra, e que constituirá, nesse caso, uma resenha crítica negativa ou favorável à obra analisada.

Bem, tal escritor chamava-se José de Alencar, e seu livro de 1865 é Iracema, lido pelo então jovem crítico Machado de Assis. Eram amigos, admiravam-se mutuamente. A apreciação de Iracema levada a cabo por Machado é abertamente favorável ao livro, elogiosa, mesmo que aponte alguns pequenos defeitos que o crítico julga fáceis de corrigir, e que já tinham sido detectados pelo próprio autor, em seu citado posfácio. Ao final de sua resenha crítica, escreve Machado de Assis: "Tal é o livro do Sr. José de Alencar, fruto do estudo, e da meditação, escrito com sentimento e consciência" (Assis, 1997, p. 852). Para chegar a esse juízo, no entanto, foi necessário demonstrar aos leitores que o livro era digno de atenção - descreveu-se o romance. E a descrição, como já disse, acompanha as indicações dadas por José de Alencar acerca da escrita de Iracema.

A resenha de Machado de Assis pode ser dividida em partes. Abre-se com um debate acerca do indianismo literário, de sua validade e alcance na literatura brasileira, suas limitações e seus melhores artífices. Logo depois introduz-se o núcleo mais propriamente opinativo do texto, que não deixa de ser descritivo já que intenta re- 
construir o processo da escrita alencarina. Segue-se a isso uma longa descrição do enredo do romance, de seus personagens, de cenas específicas reconstruídas pelo crítico, e finalmente de seu peculiar trabalho de criação de uma linguagem, e de seus pequenos defeitos. O texto fecha-se com o elogio definitivo: não é possível abarcar sua totalidade, deve-se, na verdade, ler Iracema: "Do valor das imagens e das comparações, só se pode julgar lendo o livro, e para ele enviamos os leitores estudiosos" (Assis, 1997, p. 852).

Ora, o posfácio que fecha Iracema é a famosa "Carta ao Dr. Jaguaribe", na qual Alencar descreve que poderíamos chamar de uma genealogia de seu romance indianista. Lá ele reconstrói todo um processo de anos (na verdade, Alencar remonta à polêmica por ele sustentada contra o poema "A confederação dos tamoios", de Gonçalves de Magalhães, de 1856; já então, há mais de nove anos, Alencar se batia por uma literatura indianista diferenciada), de um projeto de escrever um épico indígena para a literatura brasileira, da desistência desse projeto, e de sua transformação de poesia para a prosa - prosa poética, o romance ou novela Iracema. Alencar atribui a frustração de seu projeto de tornar-se poeta indianista à inadequação de linguagem que seria intrínseca a tal gênero: segundo ele, os personagens índios não poderiam se expressar da forma clássica como faziam na poesia de Gonçalves Dias, por exemplo. A prosa seria mais flexível, mais aberta a inovações - e a "experiência em prosa" acabou por transformar-se no livro que conhecemos. Diga-se que experimento é um bom termo para definir Iracema, já que sua linguagem altamente estilizada, sua construção por símiles e metáforas era algo inédito na literatura brasileira (e me parece que encontrará continuação, de certa maneira, no romance de Guimarães Rosa). Conta-nos Alencar (2006, pp. 278-9): 
Em um desses volveres do espírito à obra começada, lembrou-me de fazer uma experiência em prosa. $\mathrm{O}$ verso, pela sua dignidade e nobreza, não comporta certa flexibilidade de expressão que entretanto não vai mal à prosa a mais elevada. A elasticidade da frase permitiria então que se empregassem com mais clareza as imagens indígenas, de modo a não passarem desapercebidas.

Descreve-se dessa maneira o porquê de o livro ser como é; e o autor (p. 279) completa ainda a descrição chamando a atenção para a linguagem particular do livro, sua novidade, dentro dos termos de um gênero do romance romântico:

Este livro é, pois, um ensaio ou antes mostra. Verá realizadas nele minhas idéias a respeito da literatura nacional e achará aí poesia inteiramente brasileira, haurida na língua dos selvagens. A etimologia dos nomes das diversas localidades e certos modos de dizer tirados da composição das palavras são de cunho original.

Apresenta-se o livro a um leitor, o Dr. Jaguaribe, amigo cearense de José de Alencar. Apresenta-se, é óbvio, a qualquer possível leitor do livro ("Se algum leitor curioso se puser à escuta, deixá-lo" [Alencar, 2006, p. 273]): assim o entendeu Machado de Assis, crítico literário, que buscou ler Iracema de forma a pôr à prova a história contada pelo autor acerca da escrita do livro. Machado de Assis escreveu, em primeira instância, para leitores de jornal (Diário do Rio de Janeiro, 23/01/1866) - era preciso, portanto, "vender o peixe" ao mesmo tempo em que se tecia considerações mais complexas acerca da composição literária. Por isso a descrição de passagens do romance, a caracterização dos personagens principais, que pode nos parecer um pouco redundante hoje, mas que se faz fundamental para atiçar nos leitores a curiosidade quanto ao exotismo daquilo que se avalia. Note-se, no entanto, que Machado chama a atenção para um 
exotismo que não é apenas o do enredo, ou da ornamentação indianista de vocabulário e cenário. Machado (1997, p. 849) vai ao cerne da questão tratada por Alencar, ao localizar na língua do romance a contribuição mais decisiva para a literatura brasileira:

Estudando profundamente a língua e os costumes dos selvagens, obrigou-se o autor a entrar mais ao fundo da poesia americana; entendia ele, e entendia bem, que a poesia americana não estava completamente achada; que era preciso prevenir-se contra um anacronismo moral, que consiste em dar ideias modernas e civilizadas aos filhos incultos da floresta. $\mathrm{O}$ intuito era acertado; não conhecemos a língua indígena; não podemos afirmar se o autor pôde realizar as suas promessas, no que respeita à linguagem da sociedade indiana, às suas ideias, às suas imagens; mas a verdade é que relemos atentamente o livro do Sr. José de Alencar, e o efeito que ele nos causa é exatamente o mesmo a que o autor entende que se deve destinar ao poeta americano; tudo ali nos parece primitivo; a ingenuidade dos sentimentos, o pitoresco da linguagem, tudo, até a parte narrativa do livro, que nem parece obra de um poeta moderno, mas uma história de bardo indígena, contada aos irmãos, à porta da cabana, aos últimos raios do sol que se entristece.

A descrição é exatíssima: a língua de Iracema não cessa de nos causar estranhamento: quem fala assim? Nem índios, nem portugueses, muito menos os brasileiros da colônia ou do século XIX. A contribuição maior de Alencar para a ficção nacional encontra-se em fixar um lugar-nenhum da língua, que dá ao romance esse tom primitivo buscado em vão por todos os nossos poetas indianistas. E tal língua é criação original de Alencar, que nem tinha, inclusive, conhecimento extenso da cultura e das línguas indígenas. É uma criação poética, no sentido amplo da palavra, uma fabulação narrativa que instaura uma nova história, particular, subjetiva. Finaliza Machado (1997, p. 849): “A conclusão a tirar daqui é que 
o autor houve-se nisto com uma ciência e uma consciência, para os quais todos os nossos louvores são poucos".

A apreciação extremamente positiva do livro de Alencar mostra um crítico mais que atento ao trabalho do autor: pode-se acompanhar, no trecho citado, o percurso da leitura crítica - Machado parte das teses alencarinas expostas no posfácio "Carta ao Dr. Jaguaribe" (Alencar, 2006, pp. 273-80), que acompanha Iracema, coloca-as à prova na releitura minuciosa do romance e chega à conclusão de que as experiências formais que lhe constituem o cerne foram bem-sucedidas na medida em que, primeiro, alcançam um efeito no leitor análogo ao desejo autoral; segundo, expõem na matéria romanesca o trajeto reflexivo do autor, "ciência e consciência", motivos pelos quais os louvores do crítico são justos, na medida.

Antes de chegar, portanto, a um julgamento positivo de valor, Machado de Assis necessita retomar não apenas os aspectos exteriores, visíveis, do romance; necessita mergulhar nas camadas que constituem Iracema historicamente enquanto criação romanesca e, ao mesmo tempo, lírica. Por isso é tão importante, para a análise da relação obra e crítica aqui exposta, o exame da reconstrução feita por Alencar de seu processo de escrita, e o posterior exame crítico de Machado de Assis desse mesmo processo e de seus efeitos perceptíveis na análise da superfície da obra. Há um jogo complexo de leituras que ratificam um processo de escrita. Há uma segunda narrativa, portanto, subterrânea, a ser lida em Iracema. Essa narrativa desdobra-se, nos textos dos dois autores, pela descrição de um processo criativo - que só faz sentido ao deixar-se transparecer na descrição da matéria do romance em si.

Como se descreve um romance, eu perguntaria, para finalizar. Sim, me parece que Machado de Assis consegue descrever o romance que resenha, dando aos seus leitores não só uma ideia de suas 
figuras principais, de seu caráter, do modo como falam, e mesmo de sua trajetória de vida e de morte. Mas Machado não era apenas um resenhista. Era um leitor interessado e emocionado frente ao que ele considerava uma obra-prima da então ainda não consolidada literatura brasileira. Por isso, para tentar captar o âmago criativo da lenda indianista, Machado julga necessário mergulhar nessa narrativa profunda que rege o destino da virgem dos lábios de mel.

Se Iracema é um momento complexo em nosso Romantismo, alegra perceber que o romance teve um leitor à sua altura logo no primeiro momento; o que é aqui mais interessante, no entanto, é constatar que o uso sofisticado do arsenal indianista/brasileirista não encobriu o tour de force formal, produto da reflexão continuada sobre os meios da escrita. Tal reflexão, descrita por Alencar em seu posfácio à obra, é retomada por Machado com todo o cuidado de um leitor atento à matéria com que lidava. Descrever o romance é aqui gostar do romance: não há, nesse caso, imparcialidade que se justifique. Os louvores são poucos, na expressão de Machado, porque o mero reconhecimento da complexidade envolvida na escrita do livro já inclui a aceitação tácita de sua maestria. Descrever Iracema é tentar dar a um leitor uma ideia, mesmo que longínqua, do frescor que habita suas páginas, do estranhamento que nos causa, das imagens de uma natureza e de pessoas que não existem em outro lugar além das páginas do livro. Essa ideia é pálida, como conclui o próprio Machado: há que se ler Iracema. E a leitura não pode ser substituída por qualquer descrição, por mais completa que seja.

Imagino que Machado de Assis, ao fechar sua resenha crítica de Iracema, pretendia inaugurar uma tradição de leitura daquele romance, e não apenas interessar aos possíveis leitores. Por isso aqui a dimensão maior da descrição dentro da crítica literária. Ela é um marco de abertura, ela descortina a matéria a ser avaliada; e, 
no entanto, a descrição já é em si, como não poderia deixar de ser, opinativa. A descrição do romance Iracema feita por Machado de Assis é cuidadosa, amorosa. Esse amor recobre não apenas o livro em questão, mas espalha-se pela antecipação de uma possível literatura brasileira medida por "obras de tão superior quilate”. Descrição subjetiva de matéria subjetiva. Conclui, entre a imprecisão da forma e a precisão do juízo, Machado de Assis (1997, p. 852): "Poema lhe chamamos a este, sem curar de saber se é antes uma lenda, se um romance: o futuro chamar-lhe-á obra-prima”. 


\section{Referências}

ALENCAR, José de. “Carta ao Dr. Jaguaribe”. Iracema. Cotia, São Paulo: Ateliê Editorial, 2006.

ASSIS, Machado de. Obra completa (Vol. III). Rio de Janeiro: Nova Aguilar, 1997.

CAMPOS, Haroldo de. "Iracema: uma arqueografia de vanguarda". Metalinguagem \& outras metas. São Paulo: Perspectiva, 2006.

PAZ, Olegário. s.v. "Descrição". E-Dicionário de termos literários (EDTL). Coord. de Carlos Ceia, ISBN: 989-20-0088-9. Disponível em: http://edtl.fcsh.unl.pt/encyclopedia/descricao/. Acesso em 10 jun. 2018. 
Éverton Barbosa Correia

O ensaio de Eduardo Prado na Revista de Portugal anterior à publicação de Fastos da ditadura militar no Brasil 
A imagem de Eduardo Paulo da Silva Prado que chega até nós é a de um autor plenamente identificado com a monarquia, menos pela adesão a seu ideário do que pela reação ostensiva e sistemática à governança republicana recém-instalada no poder. A virulência de sua reação tem as motivações das mais variadas ordens, pois é bem sabido que Dom Pedro II frequentava a casa de sua mãe, Dona Veridiana, plantada numa rua do bairro paulistano de Santa Cecília, a qual atualmente recebe o nome da matriarca. A informação interessa para que possamos dimensionar melhor o alcance da dinastia, em torno da qual se reunia a intelectualidade brasileira, circunstancialmente paulista, cujos interesses iriam redundar na semana de arte de 1922, hoje já dissociada da família, nem tão casualmente assim. $\mathrm{O}$ fato consumado é que o primogênito de Veridiana, Antonio Prado, senador e conselheiro do Império, viria a ser líder inconteste do Partido Republicano Paulista (PRP), o qual mesmo durante o regime monarquista alistava entre suas fileiras os irmãos do meio, Caio e Martinico, ficando o caçula com o encargo de seguir o seu destino, a contrapelo da família e de suas conveniências, tendo se tornado o militante antirrepublicano mais corrosivo (Nogueira, 2003). 
Polemista acirrado, pesquisador infatigável e cultíssimo, tudo que vertia de sua pena trazia o ressaibo da amargura que o novo regime havia instaurado. É sob tal tonalidade expressiva que se constitui a persona literária de Eduardo Prado, mais monarquista do que prosador, mais pesquisador do que escritor, mais ensaísta do que militante ativo, se quisermos lhe imputar adjetivos que concorram para sua identidade autoral. Mecenas pródigo, amigo de quase todos e filho de Veridiana, mulher e sobrinha de Martinho Prado, o qual, por sua vez, era meio irmão do barão de Iguape, primeiro Antonio da Silva Prado, a um só tempo avó materno e tio-avô paterno do escritor, cuja ramificação familiar se enraíza no império desde quando o príncipe regente começou a ir a São Paulo para encontrar Domitila do Castro e Silva. Já ali a família Silva Prado interferia no destino da pátria, conforme refere Sérgio Buarque de Holanda no "Prefácio" à biografia, intitulada $O$ barão de Iguape, comentando o relato do pai da Marquesa de Santos, amante do defensor perpétuo do Brasil.

$\mathrm{Na}$ descrição da viagem do príncipe regente D. Pedro a São Paulo, em 1822, que redigiu Francisco de Castro Canto e Melo, gentil-homem de sua câmara e futuro visconde de Castro, lê-se que o dito regente recebeu na capital paulista 'a obsequiosa e magnífica hospedagem que lhe haviam preparado o brigadeiro Manuel Rodrigues Jordão e o coronel Antonio da Silva Prado, hoje barão de Iguape.... Por onde se vê que esse relato, publicado por Melo Morais, foi composto depois de 1948, ano em que Prado foi barão (Holanda, 1976, p. XI).

A despeito da distância entre a recepção imperial e o recebimento do título nobiliárquico, percebe-se que Antonio da Silva Prado, avô do ensaísta, desde longas datas teve alguma penetração na cabeça do governo e na administração do Império. Inicialmente através dos segredos da alcova imperial, para se enraizar na governança brasileira muito além da monarquia, dispondo de um legado 
inquebrantável para sua descendência direta. Não estranha, a partir disso, que no mesmo seio familiar encontrem-se partidários da república - a pretexto de se manter no poder - e defensores da monarquia - com o propósito de resguardar a tradição, tão bem ilustrada pela endogamia cafeeira praticada nos ramos daquele clã, que passa da economia para a política sem dificuldade e resvala na representação literária. Se Eduardo Prado pode facilmente ser perfilado aí, nem por isso podemos incensar sua figura com aromas de conservadorismo, porque outra é a tonalidade de seu discurso e para outro sentido se imposta o timbre de sua voz, mesmo quando partidário lascivo da tradição luso-brasileira.

Desbastada sua participação na Exposição Universal de Paris de 1889, por meio de ensaio sobre a história literária brasileira, intitulado "A língua e a literatura" (Prado, 2000, pp. 126-9), que veio a constar no livro Brésil - aqui citado em tradução e organizado por Emile Levasseur - , conviria destacar, porém, que sua internacionalização autoral se deu sob o crivo de Eça de Queirós, editor da Revista de Portugal, onde figuravam autores que vieram a constituir o panteão português, ilustrado por Ramalho Ortigão, Theófilo Braga ou Fialho de Almeida, bem como por brasileiros notáveis, mas ainda não devidamente consagrados. Até porque, em 1889, quando se inicia aquela publicação, a Academia Brasileira de Letras (ABL) ainda não existia, de onde viriam a se tornar membros os eventuais colaboradores brasileiros daquele periódico, a exemplo de Oliveira Lima, Medeiros e Albuquerque, além do próprio Eduardo Prado, ora identificado pelo pseudônimo Frederico de S. e ora assumindo sua identidade autoral. E ainda que saibamos hoje que Eduardo Prado e Frederico de S. se tratam de duas faces da mesma autoria, não foi como uma unidade autoral que sua obra foi publicada e recebida à sua época. Tanto é que, quando convertido em livro autônomo, pu- 
blicado sob o mesmo selo da Revista de Portugal, os artigos reunidos foram somente aqueles que haviam sido atribuídos a Frederico de S., que continuou a identificar a autoria, sem que o artigo assinado por Eduardo Prado fosse recolhido ali, embora constasse na primeira versão da Revista de Portugal, tal como foi organizada por Eça de Queirós. Como aquele artigo identificado pelo nome de Eduardo Prado jamais foi coligido ou publicado, apesar das reiteradas edições do volume Fastos da ditadura militar no Brasil, por isso, será o que terá precedência no argumento a se desenrolar aqui.

Acompanhando os quatro volumes constitutivos da Revista de Portugal, dispomos dos seguintes artigos assinados ou atribuídos por pseudônimo a Eduardo Prado, conforme a ordem de publicação: no primeiro volume (Queirós, 1889) - "Destinos políticos do Brasil” e "Os acontecimentos no Brasil"; no segundo volume (Queirós, 1890a) - "Os acontecimentos no Brasil", "O Brasil, fastos da ditadura", "A ditadura no Brasil, tratados diplomáticos e crédito financeiro", "As finanças e a administração da ditadura brasileira", "A república brasileira"; no volume terceiro (Queirós, 1890b) não consta nenhum artigo sob autoria de Eduardo Prado, nem pelo seu nome nem pelo seu pseudônimo; no quarto volume (Queirós, 1892), aparece este título: "Práticas e teorias da ditadura militar no Brasil". Dessa descrição, podemos depreender algumas informações, tais como a de que existe uma concentração maior de artigos no volume II, publicado 1890, no mesmo ano de publicação do livro Fastos da ditadura militar no Brasil, também editado pelos mesmos Lugan e Genelioux, responsáveis pela publicação do periódico, sucessores de Chardron, conforme está timbrado no seu frontispício. A considerar a coincidência de data e de editores, é bem possível que os artigos tenham ido ao prelo uma única vez para constar em ambas as publicações, como colaboração da Revista de Portugal e como autoria autônoma sob 
o novo título de Fastos da ditadura militar no Brasil, tragado de um dos capítulos supracitados e reunidos na Revista de Portugal, a saber, "O Brasil, fastos da ditadura” (Prado, 1890, pp. 240-58). É preciso registrar, ainda, que não só o título desse artigo sofreu alteração de uma publicação para outra, mas todos os demais, sem interferência nos respectivos conteúdos apresentados, de parte a parte, mantendo-se o mesmo texto em ambas as publicações. A mudança da coleção de artigos reunidos - seja por uma autoria única, seja por vários autores - haverá de incidir sobre a compreensão do enunciado como um todo, mas sem repercussão no conteúdo particular daqueles artigos. A variação mínima de título permite fácil identificação dos capítulos entre si, quer tomemos como referência a publicação coletiva portuguesa ou a publicação individual do autor brasileiro.

A diferença entre as duas publicações ficaria por conta de dois artigos: o primeiro é "Destinos políticos do Brasil", assinado por Eduardo Prado e coligido no volume I da Revista de Portugal, mas que não foi incorporado ao livro timbrado sob pseudônimo; e o outro, do artigo "Práticas e teorias da ditadura republicana no Brasil", somente publicado no volume IV daquele mesmo periódico, que só veio a lume em 1892, quando a governança republicana já estava consolidada e dois anos após aquela publicação autoral identificada por Frederico de S. Talvez assim tenha sido feito para não revelar de pronto a identidade autoral, que oscilava entre seu nome próprio e o daquele seu pseudônimo já constante no primeiro volume do periódico, o qual passou a comparecer pontualmente nos volumes seguintes, nos quais o nome de Eduardo Prado desaparece e o de Frederico de S. cresce, inclusive pela quantidade de páginas de cada um dos artigos do segundo volume, que se destacam consideravelmente dos artigos do primeiro, tanto daquele assinado pelo autor quanto o outro sob seu pseudônimo. 
Se a identificação autoral daquele primeiro artigo coligido na Revista de Portugal foi o motivo de sua exclusão do livro identificado por Frederico de S., sua condição de preventivo do que viesse viger no Brasil como regime político salta aos olhos, considerando que a produção literária ainda servia de veículo para o embate político. Fosse como fosse, aquele artigo da Revista de Portugal não viria a constar na primeira publicação de Fastos da ditadura militar no Brasil e, por consequência, nem em qualquer outra, mesmo depois de revelada a identidade autoral e tornado possível o cotejo entre ambas as publicações. Com isso, o artigo acaba adquirindo a feição de discurso particularizado pela autoria ali circunstanciada e, por conseguinte, não será tomado tão só como mais um artigo de Eduardo Prado na Revista de Portugal e nem como um capítulo de Fastos da ditadura militar no Brasil, o que efetivamente não foi até o momento e possivelmente nunca virá a ser, a despeito da identidade autoral ali constituída e da contiguidade dos demais artigos do mesmo autor. Por uma razão ou por outra, será tomado como um ensaio individualizado que, por sua vez, empresta conotação peculiar ao seu pronunciamento, a considerar as particularidades de sua veiculação. Por outro lado, se tomarmos Fastos da ditadura militar no Brasil como uma publicação autônoma, assinada por um pseudônimo, o livro mantém a mesma disposição e configuração inicial, embora não pudesse cumprir de todo o anúncio de seu subtítulo "artigos publicados na Revista de Portugal", ao menos se considerarmos a figura solar de seu autor, que se autonomeia e se traveste com outro nome na mesma publicação.

Sendo explicável a ausência daqueles artigos na publicação que se prestava a reunir artigos contíguos e similares entre si, sob uma autoria determinada, nada justifica a falta de menção nas edições posteriores de Fastos da ditadura militar no Brasil, até porque 
aquela ditadura, circunstancialmente nomeada, deixou de ser qualificada como "militar" e passou a ser "republicana", conforme enunciação dos próprios títulos dos artigos, o que permitiria ao menos uma visão perspectivada do processo descrito como um todo pelo autor. De qualquer modo, ambos os artigos deslocados da publicação merecem tratamento diferenciado, menos por alguma divergência discursiva em relação ao livro como uma totalidade portadora de sentido, do que pela possibilidade de oferecer uma compreensão mais aproximada do seu valor ou do seu interesse naquele momento primeiro de sua publicação. Pairando entre dois veículos autônomos entre si, mas que alvejavam igualmente a divulgação dos desmandos da governança brasileira, os dois artigos identificam a mesma persona autoral, ainda que bifurcada, já que podemos tomar a autoria de Eduardo Prado neles constituída pelo seu nome próprio e pelo seu pseudônimo, respectivamente. Todavia, há diferenças entre a circunstância de publicação e a circulação dos artigos, bem como entre a publicação dos artigos e a configuração do livro que enfeixa aqueles outros que lhe são contíguos no periódico português, excluindo-os no livro brasileiro. Essas diferenças ganharão relevo aqui pelo justo propósito de dimensionar o papel do autor no xadrez político nacional, que às vezes se estendia para além do Atlântico.

Cotejados entre si, na Revista de Portugal, os dois artigos preteridos da publicação de Eduardo Prado, ora apresentado como autor individualizado ora como pseudônimo, constituem uma espécie de moldura do livro, cujo delineamento não está grafado na imagem que se descola do quadro apresentado. Fastos da ditadura militar no Brasil se oferece, segundo a perspectiva, como um quadro sem a moldura que o define como um objeto estético circunstanciado. E a hipótese aventada aqui é a de que olhando para a moldura do quadro, ou parte dela, possamos analisar pela parte escolhida a imagem 
que o quadro se nos compunha por completo, como se pudéssemos, retrospectivamente, aferir algumas condicionantes de sua publicação e, a partir daí, ter uma experiência estética mimeticamente deslocada ou, ao menos, conferir-lhe um valor a partir dos termos de sua proposição inicial. Para tanto, deter-nos-emos, exclusivamente, ao primeiro texto na ordem de publicação da Revista de Portugal, que é "Destinos políticos do Brasil" (Prado, 1889, pp. 467-91), assinado por Eduardo Prado propriamente e publicado quando recém-proclamada a República. A duplicidade autoral de Eduardo Prado permite a visualização dos artigos autonomamente e será esta a vertente de leitura dominante a ser praticada aqui, muito embora também possam ser vistos como desdobramentos de uma mesma persona autoral, que incide diversamente sobre momentos distintos da virada republicana, a considerar que seu último artigo na Revista de Portugal só veio a ser publicado no último volume, editado em 1992, quando o regime já estava consolidado. Até porque, num primeiro momento, convinha ao autor se apresentar em primeira pessoa, ao passo que a consolidação do regime fez com que o autor se desdobrasse num outro de si, expressando-se em outra voz, supostamente alheia à sua, mas nem tanto assim.

Passemos, pois, à análise do artigo "Destinos políticos do Brasil", que se estende ao longo de 24 páginas da Revista de Portugal, portanto, com uma extensão bem maior do que o seu sucessor imediato “Os acontecimentos do Brasil” (Prado, 1889, pp. 770-6), o qual encerra sua exposição em seis páginas do mesmo volume, que marca a passagem da autoria individualizada para a do pseudônimo. $\mathrm{Da}$ quele primeiro texto, em que o autor ainda se assina como Eduardo Prado, podemos destacar duas interrogações iniciais que movem o escrito: "continuará a existir a Monarquia? Continuará a existir unido o Brasil?" As duas questões exercem funções nucleares ao longo 
do ensaio, porque, àquelas alturas, ainda não era certo que o regime monárquico houvesse se dissolvido definitivamente e a associação da integridade nacional à monarquia era o raciocínio a ser lançado de pronto, mesmo porque não havia até então outra experiência histórica gravada no chão luso-americano. Acresce a isso o fato de que a América hispânica havia se repartido num sem-número de repúblicas acaudilhadas por interesses obscuros e cujo saldo imediato era o da desvinculação entre a colônia e a metrópole. Como as colônias do Brasil e do Maranhão e Grão-Pará se emanciparam sob a chancela da dinastia bragantina, a qual continuou a governar o país unido e emancipado, soava bastante estranho uma ruptura brusca, inclusive porque, por meio da política moderada, poderiam ser identificados os possíveis elementos constitutivos de uma hipotética tradição, associada à sociabilidade encostada na religião católica, à língua portuguesa aclimatada aos trópicos ou à administração pautada por costumes lusos. Conforme fosse, o Brasil ainda figurava um braço de Portugal estendido ao mundo, em cuja extensão o autor se empenha em enxergar uma tradição constituída.

Observando o ensaio em perspectiva, é possível enxergar um movimento duplo que lhe vem a ser constitutivo. Dividido em duas partes, a primeira se volta para demonstração da insuficiência argumentativa e do esvaziamento de propósitos dos republicanos, cujo ancoradouro viria a ser uma classe média parasitária, constituída basicamente de bacharéis que dariam sustentação jurídica e retórica à decadência do latifúndio, ressentido com a política emancipatória monarquista. Enquanto que, na segunda parte, o eixo dos comentários seria pautado pelas falhas da monarquia parlamentarista, que se convertiam em alvo fácil para a retórica de ocasião dos republicanos se atracar como se em um porto seguro para defenestrar todo o aparelho do incipiente estado brasileiro. Confrontadas 
entre si, as duas partes sugerem algum tipo de correção daquele golpe insurrecional que parecia incompatível com a dinâmica institucional vigente no Brasil até aquelas alturas, bem como com as práticas sociais aclimatadas ao chão brasileiro ao longo do século XIX, que serviam de suporte para a visualização de uma possível tradição enraizada na colonização lusitana, da qual decorreria inclusive a forma monárquica. Cumpre assinalar o veio ensaístico que anima o seu escrito, cuja ambiência é dada pelo famoso quadro de Pedro Américo que ilustra o momento da Proclamação da Independência, retomando a um só tempo a emancipação nacional e o vínculo com a dinastia bragantina, inscrita na figura de D. Pedro I, em torno de quem aparecem os soldados e, num círculo mais amplo, os pardos e desbotados do processo social, pouco afeitos e familiarizados com intempéries políticas, nas quais se constituem como elemento fosco e obscuro, sem intervenção nos acontecimentos, tal como ali estão cinzelados.

Um pintor brasileiro, Pedro Américo, no seu quadro A proclamação da Independência do Brasil, retraçou o fato com toda verdade e toda filosofia. Vê-se nessa pintura o príncipe regente, a cavalo, de espada desembainhada, cercado de sua guarda de honra, dos gentis-homens da sua câmara, de vários capitães-mores e de oficiais de ordenanças. Os couraceiros, os oficiais, os da corte brandem as espadas ou agitam os chapéus e no quadro há a vida admirável daquele momento histórico. A um canto, um homem de cor guiando um carro, arreda os seus bois da estrada e olha admirado para o grupo militar; ao longe, destacando-se no fundo iluminado duma tarde que cai sobre a paisagem melancólica, um homem do campo, um caipira retém o passo à cavalgadura e voltando tranquilamente o rosto vê, de longe, a cena que não compreende. Esses dois homens são o povo brasileiro, o povo real, a maioria da população que não participou da independência e muito menos toma parte na agitação republicana promovida em torno dele (Prado, 1989, pp. 470-1). 
Não deixa de ser curioso que, para desenvolver um ensaio político e histórico, o autor tenha escolhido como ponto de apoio a cena esculpida num quadro, indiscutivelmente definido como um objeto artístico e assim é reconhecido. O ensaísta parece acreditar no poder da arte de iluminar a história e orientar o seu presente. Reproduzida à exaustão, a cena hoje conhecida por todos os brasileiros - e à sua época certamente pelos brasileiros cultos - impressiona pela riqueza de detalhes e pelo poder de síntese da Proclamação da Independência do Brasil, que serve de índice para a Proclamação da República, conforme intuição autoral realizada primorosamente na descrição do quadro "Independência ou morte". Sobretudo quando dá visibilidade ao elemento marginal estampado na imagem, que, a contrapelo do movimento histórico, o quadro mostra através do caipira na sua cavalgadura e um homem de cor, arredando bois, sem o entendimento exato do que se passava ali. O episódio, de fato, se faz bastante ilustrativo dos processos históricos que animam a sociabilidade deitada no chão brasileiro, revelando-se em momentos decisivos da emancipação nacional, o que pode ser ilustrado em ambas as proclamações, a da Independência e a da República.

A centralidade do quadro de Pedro Américo, como se sabe, é dada pela figura do príncipe regente ali tornado simbolicamente rei e que provoca uma onda que serpenteia todos os dragões do império, o que pode ser percebido pelos movimentos de seus penachos e dos rabos de seus cavalos. Mas esse movimento não foi realçado pelo ensaísta, porque daria visibilidade à arbitrariedade da subida e da consagração imperial e porque reproduziria a marginalidade popular, inscrita no quadro, contra a qual se insurge, uma vez que se pretende identificar com o povo, que defende. Por isso, a sobreposição muito ligeira da figura imperial do quadro pelo republicano da ocasião de 
sua escrita, igualmente revolto por militares, parece forçosa se considerarmos tão somente a troca dos penachos por chapéus.

O mais curioso é que, ao longo do ensaio, a ênfase seja dada às figuras dos militares, dos bacharéis e dos proprietários de terra, ao contrário do que enfatiza no quadro, como se ali interessasse o elemento marginal a ser defendido, conforme um sintoma social, e na vida prática o elemento estruturador a ser denunciado e, possivelmente, combatido. Sem inverter os lugares postos no objeto artístico, o que ali é contingente e acidental não ganha lugar de destaque no corpo do ensaio. Mas com o fito de acompanhar sua descrição dos tipos sociais atuantes naquela narrativa, comecemos pela figura dos bacharéis que tampouco aparecem com nitidez no quadro de Pedro Américo. Por outra, constituem-se como elemento estranho à representação pictórica que deu ensejo ao ensaio, mas que servem exemplarmente para sua denúncia.

O que se está chamando no Brasil o movimento republicano é um movimento de descontentes, todos formando uma minoria na classe dos privilegiados possuidores de terra ou dos indivíduos a quem couberam parcelas de instrução superior - homens feudais ou homens de pena - colocados acima do pobre ou do iletrado. [...] Os bacharéis constituem quase exclusivamente a classe dos políticos. Ora, a política vem a ser, em toda a parte, mais ou menos, a arte de ganhar eleições e de obter empregos. No Brasil, o caso agrava-se porque a deficiente organização social e econômica não dá às atividades as ocasiões de sucesso normalmente possíveis no comércio, nas indústrias (Prado, 1889, p. 471).

Se na descrição do quadro de Pedro Américo parecia natural ao ensaísta que sobrepusesse o movimento da espada do republicano ao do primeiro império brasileiro, agora aqueles mesmos republicanos são aproximados da figura do bacharel, excluído da pintura oitocentista, mas não da governança brasileira, para a qual o serviço 
público funcionava como ancoradouro dos letrados descontentes. À falta de sucesso no comércio e na indústria corresponde um inchaço na vida pública, que se traduz inclusive em elemento verbal, organizado retoricamente. Decerto Eduardo Prado se sentia muito à vontade para fazer tais afirmações, visto que, sendo bacharel por formação e parte de uma família que esteve à frente da exportação do café numa época em que representava algo como $75 \%$ da receita brasileira (Levi, 1977, pp. 159-60), estava autorizado a fazê-lo. Todo o seu repertório o levaria a dizer com precisão quais os entraves do comércio exterior, bem como seu correspondente limitante da indústria nacional. Irmão de Conselheiro do Império, convertido em líder republicano, e de republicanos ativos quando ainda da vigência da monarquia, sua fala adquire valor representativo, mesmo por ocasião da sobreposição de espadas - fossem imperiais ou republicanas - ao menos como uma experiência familiar com a qual nunca se identificou de todo, embora tampouco conseguisse suprimir de uma vez só, tal como quando descreve os partidos de então.

Os partidos estão convencidos da inutilidade de todos os seus esforços pela conquista do poder, se em socorro deles não vier a intervenção imperial. Daí resultam a fraqueza das oposições, a insolência dos governos e a situação falsa e desmoralizada dos chefes políticos, dependendo diretamente, não do corpo eleitoral, mas do Imperador, eixo único do estado, em torno do qual gira toda a máquina da vasta monarquia brasileira. [...] O mal está em não se haver o povo educado na época própria, está no hábito adquirido. O que podia ser tolerado como uma exceção temporária no sistema de governo, tornou-se a essência mesma do governo. Os homens mais eminentes do Brasil tem atribuído sem razão a permanência desta monstruosidade constitucional do Imperador, quando é evidente que ele só não pode transformar num povo livre um eleitorado, cuja maioria vota sempre com o governo. Muito menos pode o Imperador, sem a cumplicidade dos políticos, manter a sua exprobrada onipotência (Prado, 1889, p. 473). 
Ao que parece, a ideia de povo acionada anteriormente não se reproduz aqui, uma vez que o povo nomeado agora está associado aos políticos como seus legítimos representantes. Representantes vinculados a partidos que se submeteram a relações viciosas com o governo, as quais, justificáveis como atos de momento, sedimentaram práticas que se fizeram regulares, encalacrando num labirinto sinuoso o Imperador e os representantes partidários, sem os quais a governança não seria possível. Colados na orientação imperial, não havia meio de pensar outra alternativa àquele sistema, senão pela deposição da sua figura central, que chamava para si toda sorte de responsabilidades, agraciando ocasionalmente a uns e desagradando sempre a maioria. Como a substituição do imperador não resolveria o impasse, o raciocínio imediato seria o de substituir integralmente o sistema, e não apenas uma de suas partes. Por esta outra angulação, os argumentos de Eduardo Prado parecem convincentes sobretudo se considerarmos o público a que ele se dirigia.

O bacharel, a entidade falante e escrevente no meio brasileiro, nem sempre pode ser empregado, nem sempre pode tirar lucros da vida de advogado. Pode, porém, ser republicano, isto é, falar do povo em nome dele povo, sem que este ouça ou o tenha nomeado seu representante. [...] Muitos dos antigos proprietários de escravos, devedores insolváveis dos bancos e dos capitalistas, condição que já muito os dispunha para o papel de descontentes, injuriam a monarquia pelo crime imperdoável de haver presidido à liberdade dos escravos. O bacharel é o porta-voz do escravista despeitado. A vingança de um quer ser servida pela ambição de outro. Um quer destruir a monarquia que lhe tirou o negro, outro, parasita social improdutivo, cliente devendo obediência ao patrono, verdadeiro escravo a quem não aproveitou a abolição, escravo sabendo gramática e entendendo de lei, como os tinham os grandes romanos, esse bacharel, sicário movido do ódio alheio, quer tirar proveito de alguma coisa nova que surja no estado. Por trás do orador, do jornalista, está muitas vezes o antigo e incipiente senhor de es- 
cravos transformado em apóstolo de todas as liberdades, exceto a do governo (Prado, 1889, pp. 474-5).

Qualificado como entidade falante e escrevente, o bacharel ilustra um tipo social cuja função linguística é mais instrumental do que afirmativa de uma condição, mesmo quando articula a palavra "liberdade" como uma reivindicação sua. O argumento perfilado sem meias tintas por Eduardo Prado tanto mais adquire valor de verdade, quanto mais assinalarmos sua tonalidade expressiva, para a qual o estilo prefigura um posicionamento político mais reflexivo do que conformado e, contraditoriamente, mais conservador de uma hipotética tradição existente no solo luso-brasileiro do que entusiasta de licenciosidades republicanas, validas de armas que se escudam no interesse popular. Sem hesitar sobre quem seria o beneficiário das liberdades apregoadas, conviria lembrar que seu lugar social era o da gente majoritariamente responsável pela expansão cafeeira para o oeste paulista, cujo exemplo dado pela sua família dispunha sobejamente de vários tipos sociais, todos eles decorrentes da condição básica de ser bacharel, o que se aplica inclusive ao próprio ensaísta indignado, que via com horror o braço armado do Estado se voltar contra a autoridade imperial.

Os republicanos, desejando mudar a forma de governo do país porque a monarquia não é bastante liberal, e desejando restaurar a liberdade política, pensam assegurá-la por meio de uma insurreição militar. Os restauradores da dignidade cívica dos cidadãos aceitam a república nascida da indisciplina dos quartéis. Esta indisciplina é todos os dias insuflada à tropa pelos jornais republicanos; qualquer oficial pouco respeitoso aos seus superiores é incensado e engrandecido; qualquer veleidade de caudilhismo manifestada por um general ignorante é logo afagada e um simples sargento, desde que é insubordinado é um longo herói, com que a causa republicana pode e deve contar. É fácil avaliar o perigo para a civilização brasileira dum conflito entre a tropa e o regime legal (Prado, 1889, pp. 477-8). 
É espantosa a verticalidade do argumento, porque descreve aquela circunstância e adverte, ao mesmo tempo, do perigo a que o país estaria exposto com a aceitação daquelas práticas. Torna-se imperativo lembrar que a insubordinação militar passou a vigorar no espaço social e político brasileiro, a partir de então, como um critério de verdade incontornável, a considerar toda sorte de "tenentismo" que animou a chamada República velha, e mesmo quando convertida em nova República o aparato militar se viu autorizado a intervir na ordem social e política sempre que houvesse qualquer laivo de desordem ou os interesses dos descontentes pudessem ser contemplados em detrimento da ordem, ocasionalmente democrática. Daí a força do argumento se inscrever menos no seu valor histórico, capaz de descrever a particularidade de um momento decisivo para o desenvolvimento nacional, do que pela perspicácia ensaística de perceber ali um vetor civilizacional que passaria a compor o modo de fazer política no Brasil, para além daquela circunstância, repercutindo ainda nos nossos dias. Também por isso, o ensaio histórico se potencializa em sua dimensão literária, porque é capaz de transcender à transitoriedade de um instante, por mais contraditório que parecesse, ao menos nas palavras daquele rebento tardio da endogamia cafeeira.

No emaranhado do seu discurso, o próprio Eduardo Prado não sabia aferir a extensão da República recém-instaurada nem o alcance exato de suas formulações. O resultado disso é um desencontro constitutivo da sua expressão, não necessariamente apaziguadora, em face do regime que se consolidava. $\mathrm{O}$ seu artigo se faz, a um só tempo, registro da encruzilhada em que se viu a intelectualidade e a elite brasileira, as quais curiosa e cumulativamente estão representadas no autor, cuja expressão tremula um impasse social, que se confronta com a moralidade vigente. $\mathrm{O}$ veio discursivo aberto por este seu texto se 
ramifica em outros tantos, inclusive àqueles publicados em números posteriores da mesma Revista de Portugal. Mas como até aqui o autor não havia se expressado por meio de um pseudônimo, trata-se, portanto, de um momento anterior à escrita daqueles artigos que vieram a compor o livro Fastos da ditadura militar no Brasil, coligidos inicialmente na Revista de Portugal. No ensaio ora analisado, podemos flagrar um momento em que ainda havia a ilusão ou a esperança de que a monarquia podia ser restaurada, a cuja ilustração segue um parágrafo da segunda parte daquele escrito.

A monarquia, isenta das funestas responsabilidades que hoje lhe dá o encargo inteiro da nação, será a ordem, a paz e a unidade, assentando sobre a base larga e firme da união de províncias fortes e não fracas e descontentes como hoje. A sua influência moral ganhará com o seu progresso e a sua democratização. A missão nacional do povoamento e da utilização do solo será mais rapidamente cumprida e melhor sucedida se, em vez de ser mal dirigida de um ponto único e distante, ela for desempenhada pelas províncias limitando a cada uma os seus esforços, por isso mais eficazes, dentro do próprio território. O elemento estrangeiro é no Brasil a civilização. $\mathrm{O}$ imigrante é o professor nacional do trabalho, o fator e o mestre primeiro da produção de riqueza. [...] As províncias ensinarão umas às outras os meios de adiantamento moral e material que forem adotando e em vez da legislação única que trata igualmente coisas e pessoas desiguais, as leis provinciais terão um caráter experimental que falta à legislação uniforme de outros países (Prado, 1889, pp. 490-1).

A utilização do tempo verbal no futuro é indicativa de uma vontade de interferência nos acontecimentos, que ainda parecia possível, fosse pela proximidade do golpe republicano do tempo de publicação do escrito, fosse pela imprecisão do alcance de sua prosa, o fato é que Eduardo Prado fez render a sua prosa por um viés totalmente inusitado, se considerarmos o que se praticava então como 
narrativa histórica ou memorialística e o que foi praticado discursivamente por Eduardo Prado naquele momento hostil para o desenvolvimento sociocultural brasileiro. $\mathrm{O}$ argumento de que a restauração monárquica seria possível, hoje, pode parecer até risível, como se um arranjo na legislação transformasse a relação das províncias entre si e com a corte, o que sugere algo como uma monarquia federativa, e não apenas parlamentar. Difícil é imaginar, a partir daí, uma relação interprovincial, quando houvera uma concentração das fazendas de café, bem como da mão de obra importada, cujo resultado imediato foi o da precedência de umas províncias sobre as outras. Sendo a sua província natal a que mais cresceu, Eduardo Prado só afirma existencialmente o poço de contradições que nunca deixou de ser, ao longo dos seus quarenta anos, notadamente no espaço institucional da política ou da família tradicional da qual proviera, que às vezes se confundiam diante de seus olhos míopes e às vezes se lhe revelavam como instâncias distantes de si, que ele talvez pudesse emendar. Nunca tendo consertado uma coisa nem outra, nunca deixou de incomodar a todos como uma força expressional viva e de uma representação social incomum do mundo que esteve à sua volta, ocasionalmente girando para lados distintos. 


\section{Referências}

FREDERICO DE S. Fastos da ditadura militar no Brasil. Porto: Revista de Portugal, 1890.

HOLANDA, Sérgio Buarque de. "Prefácio". In PETRONE, Maria Thereza Schorer. O barão de Iguape: um empresário da época da Independência. São Paulo: Ed. Nacional; Brasília: INL, 1976, pp. XI-XX.

LEVI, Darrel Erville. A família Prado. São Paulo: Cultura 70, 1977.

NOGUEIRA, Octaciano. "Um homem contra um regime". In FREDERICO DE S. Fastos da ditadura militar no Brasil. São Paulo: Martins Fontes, 2003, pp. IX-XVII.

PAGANO, Sebastião. Eduardo Prado e sua época. São Paulo: O Cetro, 1960.

PRADO, Eduardo. “Destinos políticos do Brasil”. In QUEIRÓS, Eça de (org.). Revista de Portugal, v. 1, pp. 467-91, Porto: Lugan \& Genelioux editores, 1889.

“Os acontecimentos do Brasil". In QUEIRÓS, Eça de (org.).

Revista de Portugal, v. 1, pp. 770-6, Porto: Lugan \& Genelioux editores, 1889.

“O Brasil, fastos da ditadura”. In QUEIRÓS, Eça de (org.). Revista de Portugal, v. 2, pp. 240-58, Porto: Lugan \& Genelioux editores, 1890. 
. "A língua e a literatura”. In LEVASSEUR, Emile. O Brasil. Rio de Janeiro: Bom Texto; Letras e Expressões, 2000, pp. 126-9.

QUEIRÓS, Eça de (org.). Revista de Portugal, v. 1, Porto: Lugan \& Genelioux editores, 1889.

_. Revista de Portugal, v. 2, Porto: Lugan \& Genelioux editores, 1890a.

Revista de Portugal, v. 3, Porto: Lugan \& Genelioux editores, $1890 \mathrm{~b}$.

Revista de Portugal, v. 4, Porto: Lugan \& Genelioux editores, 1892. 
Fátima Cristina Dias Rocha

O conto zero e outras histórias e Pai, pari: Sérgio Sant'Anna e João Silvério Trevisan visitam o "museu da memória" 
[...] há um sentido ficcional na autobiografia muito intenso. Qualquer história que é recontada tem um nivel muito grande de invenção, de fantasia. O imaginário preenche um monte de lacunas, altera fatos sem que você se dê conta.

João Silvério Trevisan. Jornal Rascunho.

O prestígio alcançado, hoje, pelos relatos autobiográficos - e livros como Na minha pele, de Lázaro Ramos, e Rita Lee: uma autobiografia exemplificam o apreço do público por tais relatos - leva-nos a refletir sobre os caminhos da escrita memorialística no Brasil, especialmente aquela elaborada por intelectuais dedicados ao universo da literatura e do jornalismo, entre outras áreas.

Do século XIX às primeiras décadas do século XXI: este é o percurso que pretendemos acompanhar, em rápido voo, no presente ensaio, com o objetivo de, dedicando a nossa atenção a relatos autobiográficos/memorialísticos de escritores contemporâneos, verificar suas estratégias discursivas, as percepções de si que os norteiam e a potência reflexiva e crítica que contêm, tanto no âmbito da vida 
literária de seu tempo quanto no que diz respeito ao contexto sociocultural em que se inserem e sobre o qual atuam.

Lembro aqui, antes de iniciar nosso percurso, as palavras de Sylvia Molloy acerca das convenções vigentes no momento da escrita da autobiografia. Diz a estudiosa:

Assim como cada período volta a pensar os gêneros e as práticas, também pensa os meios que asseguram o bom funcionamento destes gêneros e destas práticas. Dito de outra maneira, e com relação à autobiografia, cada período tem sua própria concepção de memória, das maneiras de recordar que farão com que a escrita do eu coincida com o que a época espera do gênero (Molloy, 2003, p. 225).

Corroborando a afirmação de Sylvia Molloy, ressaltamos que, no século XIX, o relato memorialístico buscava a sua legitimidade por meio do caráter de testemunho que apresentava, o qual o aproximava, em alguma medida, da História. Dois importantes livros de memórias escritos no século XIX, embora publicados apenas no século XX, são Minhas recordações, de Francisco de Paula Ferreira de Rezende, e Memórias, do Visconde de Taunay. Sobre o primeiro, disse Antonio Candido que

Minas Gerais produziu o melhor livro brasileiro de memórias do século XIX, as Minhas recordações [...], escritas de 1887 a (provavelmente) 1890 e publicadas apenas em 1944. [...] Francisco de Rezende alcança naturalmente o cunho generalizador através da sua candura arguta e do desejo de fazer viver o seu tempo e o seu meio, graças ao relato da sua vida (Candido, 1987, p. 53).

Como efeito da intenção de mostrar os aspectos mais universais nas ocorrências mais particulares, a infância do memorialista serve à finalidade "documental" do autor, como o evidencia o seguinte trecho, incluído no índice da obra: "V. As recordações que 
mais vivas se conservaram na memória infantil do autor foram as da vida política do país. A explicação do fato pela influência do meio em que viveu" (Rezende, 2015, p. 10). A propósito, no "Prefácio" da segunda edição de Minhas recordações (2015), a historiadora Mary del Priory (2015, p. 23) anotou: "O Brasil dos I e II Reinados são passados a limpo na radiografia precisa e encantatória de sua narrativa”. Também o Visconde de Taunay, em suas Memórias, atende às duas exigências que a literatura no Brasil buscava cumprir: a fidelidade documental e o compromisso com a representação do país. Como em Minhas recordações, a infância do Visconde de Taunay não ocupa mais do que alguns capítulos iniciais do livro, e sua inserção no relato se deve, em boa parte, a um dos grandes intentos do monarquista Taunay, ao escrever suas memórias: a homenagem reverente ao Imperador Dom Pedro II e ao Brasil que este representava, nação evocada pelo memorialista com nostalgia e com pesar por seu desaparecimento. A significação histórica e o valor documental da obra ampliam-se na segunda e na terceira partes, que ganham dimensões heroicas e dramáticas, possibilitadas pela participação do engenheiro Taunay, em 1865, na expedição que atacaria a República do Paraguai por Mato Grosso. Em suas Memórias, portanto, Taunay combinou a "vocação relatora da experiência pessoal" e "a capacidade realista de observação objetiva" (Zagury, 1982, pp. 22-3) para elaborar um largo depoimento sobre um relevante período da vida nacional. Outro autobiógrafo do mesmo período que não podemos esquecer é Joaquim Nabuco, com Minha formação (1900), que, relembrando sua formação intelectual e reconstituindo uma época do país, acrescenta ao seu relato a evocação emocionada da infância, no antológico capítulo "Massangana”, ainda que tal evocação sirva para justificar a sua trajetória de militante do abolicionismo. 
Entretanto, se, em cada época, a escrita da autobiografia corresponde a um determinado "horizonte de expectativas", identifica-se nessa escrita uma construção retórica comum, chamada por Sylvia Molloy de "retórica autobiográfica". Compõem tal retórica algumas formas privilegiadas - cenas primárias textuais, nas palavras de Sylvia Molloy (2003, p. 33) - que ocorrem com mais frequência como autobiografemas básicos: a primeira lembrança, a elaboração do romance familiar, a fabulação da linhagem, a ficcionalização da infância, o destaque do ato de ler, a encenação dos "lugares da memória”, entre outros. A precedência e a relevância concedida a um desses autobiografemas; o descarte de algum(ns) dele(s); o modo como são articulados: essas variáveis se devem ao que a época espera do gênero autobiográfico e à imagem de si que o autobiográfico deseja construir.

Com efeito, em meados do século XX - quando os escritores que haviam participado do movimento modernista já estavam, quase todos, consagrados -, os relatos autobiográficos e/ou memorialísticos ganharam novas inflexões, dentre as quais destacamos: em lugar da identificação com o país e do caráter exemplar da vida construída na narrativa, a ênfase no espaço regional e até mesmo familiar, ambos (re)constituídos nostalgicamente pelo autobiógrafo; ao invés de estratégias textuais que procuram apagar o tom emotivo em favor da organização racional do relato, a elaboração de um discurso que enfatiza (por meio de recursos diversos, que variam de acordo com a modelagem de si que o autobiógrafo deseja configurar) a emoção do narrador: tanto a que ele afirma ter experimentado, quanto a que ele vive no momento em que escreve; e em lugar da diminuta - e quase que envergonhada - menção ao período da infância, a ampla visada sobre essa etapa da vida, que às vezes ocupa, somente ela, o conjunto do relato. Muitas - e marcantes - são as autobiografias que, escri- 
tas a partir dos anos 1940, exemplificam, em modulações variadas, as "novas inflexões" referidas acima, a começar por Infância (1945), de Graciliano Ramos, a que se seguiram, entre outras: Itinerário de Pasárgada (1954), de Manuel Bandeira; Um homem sem profissão: sob as ordens de mamãe (1954), de Oswald de Andrade; Meus verdes anos (1956), de José Lins do Rego; As florestas: páginas de memórias (1959), de Augusto Frederico Schmidt; A idade do serrote (1968), de Murilo Mendes; Boitempo (1968) e Menino antigo (1973), de Carlos Drummond de Andrade; A menina do sobrado (1979), de Cyro dos Anjos. Também na década de 1970, Pedro Nava dá início à sua monumental obra memorialística, com Baú de ossos (1972), Balão cativo (1973), Chão de ferro (1976) e Beira-Mar (1979), completados com Galo das trevas (1981), O círio perfeito (1983) e o póstumo Cera das almas, em 2006. Em tais obras, os autobiografemas básicos referidos por Sylvia Molloy são atualizados por nossos autobiógrafos, ainda que cada um deles o faça à sua maneira, motivado pela autoimagem que deseja construir. Nas memórias de nossos romancistas do Nordeste, por exemplo, como em Meus verdes anos, de José Lins do Rego, a figuração do espaço da infância - o engenho do avô -, um significativo "lugar da memória", ganha especial relevo, sendo recriado sob o olhar nostálgico daquele que, no presente da escrita, vivencia os efeitos da decadência da grande propriedade rural. $\mathrm{O}$ viés nostálgico e o tema da decadência do mundo rural se estendem para outros escritores, como os mineiros Carlos Drummond de Andrade e Cyro dos Anjos, respectivamente em Boitempo e em A menina do sobrado. Em todos os autores até aqui mencionados, a ficcionalização da infância é um autobiografema intensamente explorado. E, se alguma idealização preside as "ficções da infância" de nossos escritores, ela não é a estratégia que mais se destaca em seus relatos, nos quais o memorialista evoca/inventa uma infância mar- 
cada por "tormentos" (José Lins, em Meus verdes anos), injustiça e incompreensão (Graciliano Ramos, em Infância), insegurança e solidão (Cyro dos Anjos, em A menina do sobrado), desejo sexual e religiosidade repressora (Oswald de Andrade, em Um homem sem profissão). Nas autobiografias citadas - traço que pode ser estendido a muitas outras -, a (re)criação da infância está diretamente relacionada ao escritor que, no tempo da elaboração do relato, “(re)lêe” e compõe o passado de modo a evidenciar, ao longo de seu percurso, o gradativo e penoso embate com as agruras experimentadas na infância, até o momento - o da escrita - de (às vezes, relativa) superação das marcas deixadas por aquelas agruras. Vale ainda ressaltar que, no amplo espectro que se estende de Infância a Cera das almas, o registro pessoal e o testemunho coletivo se imbricam, compondo um colorido painel de experiências individuais e vivências comuns. Retratos em miniatura de um Brasil patriarcal em vias de extinção, por suas páginas figuram os "coronéis" em decadência; as amas de leite, muitas delas ex-escravas, com suas histórias que tanto alimentaram a imaginação de nossos escritores; as casas senhoriais, representativas da família patriarcal; as novidades tecnológicas que mudaram a fisionomia das pequenas cidades interioranas. Quanto à perspectiva do memorialista, ela pode ser nostálgica e emocionada, como a de José Lins; lúdica e poética, como a de Murilo Mendes; pungente e irônica, como a de Carlos Drummond de Andrade; desencantada e crítica, como a de Graciliano Ramos; crítica e lírica, como em Cyro dos Anjos. E a relação se estenderia por tantos relatos autobiográficos escritos no período, nos quais os autorretratos ali desenhados estabelecem novos laços identitários, que tanto podem ser com a região: o Nordeste açucareiro de José Lins do Rego; quanto com a cidade: a crescente São Paulo de Oswald de Andrade; a contraditória Juiz de Fora de Murilo Mendes e de Pedro Nava; a provinciana Itabira de 
Carlos Drummond; a encantadora Santana do Rio Verde e a jovem Belo Horizonte de Cyro dos Anjos. Nesses relatos, a figuração de si faz-se em paralelo com a figuração do lugar, a autobiografia convertendo-se em heterobiografia.

Desse modo, o surto memorialístico que eclode em meados do século XX já se apresenta como um gênero "autônomo", distinto da História, mas ainda mantém um caráter documental, que não diminui a inventividade de seus autores: compostas quando tais autores já haviam elaborado uma vigorosa obra literária, as memórias exibem o domínio de recursos expressivos variados, fruto de um maduro projeto estético e ético de seus criadores.

No cenário contemporâneo, o gênero autobiográfico mantém a sua vitalidade, renovando-se continuamente por meio do contato com a multiplicidade de manifestações das escritas vivenciais, com destaque para a autoficção. Se, no final do século XX, o conceito de pacto autobiográfico (Lejeune, 2008, p. 13) contribuiu para distinguir a ficção autobiográfica da autobiografia propriamente dita, são tênues, atualmente, os limites entre o romance que tem como protagonista um personagem-escritor - romance este que pode se aproximar da chamada autoficção ou confundir-se com ela - e uma obra de cunho mais nitidamente autobiográfico, obra esta que tangencia, portanto, a autobiografia "canônica", mais especialmente aquela que, no Brasil, ganhou forma a partir de meados do século XX.

Um exemplo bem sucedido, porque inventivo, do hibridismo ficção/lembrança, encontra-se no livro $O$ conto zero e outras histórias (2016), de Sérgio Sant’Anna. São dez narrativas, algumas mais longas, outras mais curtas, a maioria delas caracterizando-se por um forte teor autobiográfico, ainda que o narrador evite usar a primeira pessoa, e, mais ainda, evite a identificação imediata entre o nome do autor, o do narrador e o do personagem. Como é comum 
ao texto híbrido, as narrativas de Sant'Anna provocam, em lugar da identificação, a ambiguidade: as experiências protagonizadas pelos personagens foram, de fato, vivenciadas pelo autor? Posso ler tais textos como autobiográficos? A resposta oscila entre o sim e o não, oscilação também prevista e provocada pelo texto híbrido. Logo, a percepção, por parte do leitor, do teor autobiográfico das narrativas se faz na medida do conhecimento que esse leitor tem da "vida" e da obra de Sérgio Sant’Anna e que está disponível em diversos paratextos: no próprio volume, como a orelha do livro, e em entrevistas do autor, entre outros. Mas aquela percepção - e nesse aspecto já se mostra a habilidade construtiva do escritor - também é efeito dos diálogos intertextuais presentes no próprio livro.

Neste ensaio, abordaremos cinco narrativas, lembrando que nosso objetivo não é somente o de atestar o cunho autobiográfico de tais textos, mas sim o de apontar as estratégias compositivas do escritor, as quais, por seu caráter experimental e inovador, revitalizam a narrativa curta, ao mesmo tempo em que ficcionalizam a lembrança, a vivência, as experiências compartilhadas com a família, amigos, intelectuais - toda uma geração.

No texto de abertura, "O conto zero", o autor coloca em cena o personagem você (para o qual utilizarei o negrito, embora o escritor não o grife desse modo), um escritor, que logo se desdobra no protagonista você, "posto em situação", o qual, por sua vez, se vê aos doze anos, em Londres, com o irmão. Para compreender esse desdobramento/deslocamento do personagem em três momentos de sua vida, é preciso acompanhar o início de tal deslocamento, ou seja, o começo do conto:

Não seria propriamente um conto, ficaria dias e mais dias rondando a sua cabeça, você não escrevia uma única frase, uma palavra que fosse, pois ela o comprometeria com um seguimento, 
um desfecho, e o que você queria era uma prosa solta, que não precisasse ser escrita e concluída; que fosse um pensamento $l i$ vre em movimento, levando-o a paragens infinitas e movediças, algo que nunca chegava a fixar-se apesar de alguma ordem. Mas se poderia argumentar: se não se escreve não é um conto, mas para você é [o você no momento da escrita], existe um protagonista, um ser que habita um corpo e agora se põe em situação, está sentado em um banco individual de lotação, você o pegou [num passado remoto, situado na segunda metade do ano de 1954] na rua São Francisco Xavier, nas cercanias de Vila Isabel, depois de ter saído do Maracanã, digamos que de um jogo entre Vasco e América, você ia a qualquer jogo, sozinho ou com o seu irmão [...]; você estava com doze anos [num passado um pouco mais remoto do que o anterior], até quase a metade deste ano de 1954 morara com a família em Londres, onde o pai fizera um curso de pós-graduação [...] e o pai também não os impedia de saírem sozinhos pela cidade estrangeira, que vocês dominavam melhor do que os adultos. Matando aula, vocês percorriam todas as estações do metrô (Sant'Anna, 2016, p. 7, grifos nossos).

A transcrição foi longa, mas ela nos permite perceber, além dos três planos temporais em que se desloca o personagem você, a explicitação do processo de estruturação do conto, que se quer "uma prosa solta", "um pensamento livre em movimento", "algo que nunca chegava a fixar-se". "O conto zero" é, com efeito, uma prosa solta, que vagueia livremente pelo você que escreve; pelo você que retorna, num lotação, do jogo no Maracanã; e pelo você que, em Londres, flanava pelo metrô, com o irmão, em aventuras transgressoras. É preciso ressaltar, no entanto, que os três você (com a variação vocês, quando o irmão está incluído) se misturam, não se fixam, como na passagem:

Mas não é bem essa história que você está contando. Aliás, como disse antes, você pretende que esta não seja bem uma história, mas um flanar escrito, [...]. Você está ali sentado, à direita do motorista de lotação, um sujeito que, naquele tempo, lhe parecia um aventureiro intrépido comandando a sua máquina. 
E, sozinho aqui sem seu apartamento, você se dá conta de que já tinha esse lado solitário - embora nem sempre - que o levava, às vezes, a pegar o bonde circular e fazer o círculo inteiro Botafogo-Copacabana-Botafogo, do mesmo modo que em Londres pegava o metrô da Circle Line, de South Kensington, fazendo uma viagem como se tivesse um objetivo (Sant'Anna, 2016, p. 23, grifos nossos).

Nesse "flanar escrito", alternam-se: o você escritor que, com suas lembranças, compõe o texto, distribuindo-as, num recurso engenhoso, entre o você que passeia pelo Rio de Janeiro e o você(s) que vagueava(m) por Londres. Com este último, o texto traz as lembranças dos tempos vividos em Londres e a viagem de volta ao Rio de Janeiro - estada em Londres referida por Sérgio Sant’Anna em suas entrevistas e depoimentos. Já o você que, no lotação, volta do jogo no Maracanã, traz as experiências da infância na rua Cesário Alvim, em Botafogo, com o seu clima cordial - a rua da infância como um significativo "lugar da memória" para o escritor —, assim como o cotidiano da vida em família, a iniciação sexual, a sensação de pertencimento à cidade carioca e a vida cultural da cidade, com destaque para a Rádio Nacional e o rádio-teatro. Nos últimos parágrafos do conto, este se detém no presente da escrita, para logo deslocar-se para um passado mais remoto, em que a figura da mãe se sobressai, revelando-se a explicação para o seu comportamento depressivo e severo:

[...] e agora você escreve aos setenta e três anos de idade sobre um passado remoto. Mas havia um passado mais remoto do que este e, uma noite, quando você tinha trinta e cinco anos, o irmão lhe confidenciou que soubera por um tio que a mãe quando solteira fora apaixonada por um sujeito chamado Hélio e ficou grávida dele, que a abandonou e ela ficou quase louca (Sant'Anna, 2016, p. 29). 
Depois dessa traumática experiência vivida pela mãe (à qual retornaremos adiante), o conto transita para uma cena anterior a todas as outras, em que o menino, depois de rezar com a mãe, adormecia "seguro que [...] iria para o céu e seria muito feliz". E, no seu final, o conto reverencia a memória e o seu poder de dar existência ao mundo: "Mas e antes disso? Antes disso você não conservava uma memória e era como se fosse ninguém. Era um momento zero em sua vida, como se nem mesmo o mundo existisse" (Sant'Anna, 2016, p. 30).

No conto seguinte, "Flores brancas", um narrador em primeira pessoa recorda um intenso relacionamento amoroso vivido por ele, quando residia em Belo Horizonte e ainda era casado, relacionamento que o fez separar-se da mulher e dos dois filhos, indo residir, com a nova companheira, no distante bairro de Venda Nova, "quase um outro município nos limites da cidade" (Sant'Anna, 2016, p. 37). O relacionamento se deteriora e entra em crise, a qual culmina com uma cena de grande dramaticidade, que separa o casal. Sozinho e vivendo tão afastado da cidade, o protagonista acaba por enfrentar sérios problemas no deslocamento para o trabalho, testemunhando cenas de intensa violência urbana, em que ônibus são apedrejados e um rapaz morre tragicamente. As "flores brancas" caem sobre o personagem quando este, já numa nova casa, se sente feliz e apaziguado. Sob o nosso viés de leitura, o conto "Flores brancas", apesar de narrado em primeira pessoa, apresenta-se como uma peça ficcional, até mesmo porque o narrador-protagonista chama-se Célio. Entretanto, também nessa narrativa, Sérgio Sant’Anna distribui alguns "operadores de identificação" (Gasparini, 2004, p. 25) que nos permitem supor que o personagem Célio reúne alguns dados autobiográficos do próprio autor, mais uma vez perceptíveis pela maior intimidade do leitor com a "vida" de Sant'Anna e - o que nos parece mais instigante - pelo sutil diálogo com outros textos do mesmo livro. 
"Vibrações", o terceiro conto de O conto zero, reconstrói, fragmentariamente, as experiências do personagem $S$ (grifo adotado neste ensaio, mas não na edição original do texto) no Programa Internacional de Escritores, em 1971, na cidade de Iowa, nos EUA. São mais de cinquenta páginas, que se dividem em dez segmentos numerados, sendo que os dois primeiros, em sua extrema fragmentação e descontinuidade, trazem as produções literárias e artísticas de intelectuais das mais diversas origens, com toda a riqueza da diversidade cultural que ali se mostrava. A partir do terceiro segmento, o relato vai ganhando maior unidade, passando a referir-se com mais insistência às vivências do personagem $S$ : a chegada ao Programa, as amizades e trocas culturais, o convívio com a esposa, $M$, quando esta passa um período em Iowa, tendo deixado os dois filhos do casal no Brasil. Mais ainda que no primeiro conto da coletânea, as "vivências de Iowa" do personagem $S$ têm uma dimensão pessoal e uma dimensão geracional, coletiva: entre os ecos das guerras da Coreia e do Vietnã, estão as “drogas, sexo e rock'n'roll”, além, é claro, da participação em manifestações artísticas experimentais. No âmbito pessoal, o conto não apenas descreve a convivência de $S$ e $M$ em Iowa, como relembra o namoro, a viagem dos namorados, em 1968, para Paris, o casamento, e alguns momentos da vida em comum em Belo Horizonte. Desta vez, a narrativa propõe a identificação entre $S$ e o escritor Sérgio Sant'Anna, ao mencionar o livro O sobrevivente, de Sant'Anna, e o nome do filho de $S$, André. Ao final, a semelhança se transforma em identificação (uso aqui as designações de Philippe Lejeune, 2008, pp. 35-6), quando o americano Kenneth Brown, que frequentara o Programa Internacional de Escritores e que estava no Brasil, pergunta: “Então, Sant'Anna, teve uma boa estadia na América?'. 'Sim', ele respondeu, tive uma ótima estadia na América” (Sant'Anna, 2016, p. 125, grifos nossos) - trecho que exemplifica o criativo emprego dos pronomes pessoais nos textos do livro. 
O conto "A bruxa", narrado em primeira pessoa, não esconde o seu teor autobiográfico, evidente no relato da visita feita pelo protagonista à escritora Clarice Lispector, em seu apartamento no Leme, seguida de uma festa na casa de Affonso Romano de Sant'Anna, da qual o narrador-protagonista participa, ao lado de Clarice. O teor autobiográfico dos dois episódios coloca sob outra perspectiva, para o leitor mais atento, experiências textualizadas em outros contos da coletânea, até então interpretadas como ficcionais ou colocadas no terreno da ambiguidade: em "O conto zero", a infância vivida na rua Cesário Alvim, em Botafogo, teria sido inspirada na do próprio autor? O relacionamento com uma outra mulher, quando ainda estava casado, teria sido uma experiência exclusivamente de Célio, o personagem-narrador de "Flores brancas"? Para respondermos a esta última indagação, podemos valer-nos do seguinte trecho de "A bruxa": "[Clarice] Também me ouviu a propósito de uma paixão que eu vivia, apesar de casado, e disse que, aos trinta e três anos, já era tempo de eu estar com a vida estabilizada” (Sant'Anna, 2016, p. 152). Quanto à infância do protagonista de "O conto zero", parece ser semelhante à do narrador-protagonista de "A bruxa", que diz: "Pois, virando o meu olhar à direita, para baixo, bem lá embaixo, tive a emoção de reviver o meu passado, avistando a rua Cesário Alvim, em Botafogo, de minha infância" (p. 154). Mas, se o leitor atento identifica o "pacto fantasmático" (Lejeune, 2008, p. 43) proposto pelo autor em narrativas como "O conto zero", "Vibrações" e "Flores brancas", esse leitor também se extasia com a habilidade compositiva de Sant’Anna, que, ao concluir o conto "A bruxa", evidencia a tarefa do contista, daquele que cria histórias: amarrando "as duas pontas" de seu texto, o narrador volta à bruxa/mariposa do primeiro parágrafo, assinalando-a como o estopim de sua ficção: "Fui impelido, então, a aproximar meu rosto do espelho, onde estivera a grande mariposa negra, ou Clarice, 
e vi que ela deixara atrás de si um pozinho, como um pólen, fertilizando talvez outras bruxas, mas fertilizando, com toda a certeza, o meu conto" (Sant'Anna, 2016, p. 155).

Por fim, o último conto do volume, significativamente intitulado "O museu da memória”, confere unidade ao livro, uma vez que tal conto reúne, justapondo-as, cenas, personagens e episódios que figuraram nos textos anteriores (além de muitas outras cenas, algumas presentes em contos do último livro do autor, Anjo noturno, de 2017). Cenas, personagens e episódios depositados no "museu da memória" do escritor:

No museu da memória estou debaixo da marquise do Grande Hotel do Louvre, em Paris, rindo por dentro quando a água que meu irmão jogou com a boca, lá do nosso quarto no hotel, cai sobre os franceses que esbravejam enfurecidos na fila do ônibus [Cena de 'O conto zero'. [...] No museu da memória há a mulher de maiô inteiriço na garupa da minha lambreta, em Ubatuba, encostando, quase imperceptivelmente, os seios nas minhas costas. No museu da memória há essa mesma mulher, vestida de noiva entrando na igreja ao som de 'Jesus alegria dos homens', de Bach, enquanto a espero no altar [Cenas de 'Vibrações']. [...] No museu da memória estamos ouvindo música em ondas curtas no radinho de pilha, diante da mata, na casa modesta da rua de terra, em Venda Nova, nos arredores de Belo Horizonte, eu e minha companheira, no meio do barulho de sapos e grilos e a visão de vaga-lumes [Cena de 'Flores brancas']. [...] No museu da memória há Kenneth Brown, em Iowa City, 1971, contando histórias do Living Theatre e da Maria. No museu da memória há Seymour Krim contando histórias da beatnik generation [Cenas de 'Vibrações']. [...] (Sant'Anna, 2016, pp. 170-2).

Além de dar unidade ao volume, este último conto esconde a chave para uma possível leitura autobiográfica de algumas narrativas de $O$ conto zero e outras histórias: guardadas no "museu da memória”, as lembranças dali saem, fecundadas pelo refinamento literário 
do escritor. Assim, não é preciso buscar, em entrevistas do autor, a possível autenticidade do caso de paixão e ódio encenado em "Flores brancas": no diálogo entre as narrativas - e na oscilação constante dos pactos romanesco, autobiográfico, referencial e fantasmático, que nos contos se alternam, "livres", "sem forma fixa" - , o leitor flagra aquela autenticidade, que parece ganhar maior relevo nos dois últimos livros de Sérgio Sant'Anna, sem que tal relevo signifique a perda da alta voltagem estética característica do autor. Um exemplo do aproveitamento ficcional de vivências do "museu da memória", no livro Anjo noturno, está no conto "A mãe", em que o escritor elabora um amoroso e delicado retrato da figura materna: sua religiosidade, seu moralismo intransigente, seus momentos e faces mais afáveis, a sua morte. É ainda nesse conto que o escritor, retomando uma situação já mencionada no texto "O conto zero", do livro anterior, desvela o surpreendente passado de sua mãe, do qual ele tomou conhecimento no ano de 1977, por meio do irmão: "ele me contou que nossa mãe havia tido um filho quando solteira e que esse filho fora criado no morro Dona Marta e lá tinha morrido antes de completar um ano de idade. E que minha mãe, quando conhecera meu pai, mantinha casos com outros homens. Fiquei perplexo..." (Sant’Anna, 2017, p. 72). Embora este não seja o cerne do conto - no qual, a propósito da evocação da figura materna, o narrador reflete sobre a morte e o suicídio e sobre as marcas profundas nele deixadas pela religiosidade da mãe - , chama a atenção a minúcia com que o narrador (p. 73) descreve a tragédia pessoal vivida pela mãe, passagem do conto anunciada com as seguintes palavras: "Vou tentar descrever, com a objetividade possível, a história dramática que se segue".

O acento pessoal e dramático da narrativa de Sérgio Sant’Anna potencializa-se fortemente no relato doído, dilacerado e contundente de João Silvério Trevisan no livro Pai, pai, publicado em 2017. O 
próprio autor pontua o significado e as funções de seu projeto autobiográfico, a ele referindo-se como "um acerto de contas com a figura do meu pai e, por extensão, com meus demônios interiores ligados à sua imagem" (Trevisan, 2017, p. 8, "Abrindo o jogo"); ou como "um ritual de cura" (p. 9, "Abrindo o jogo"); ou ainda como "um inventário de fantasmagorias", dedicado "à infância abandonada e à sua ferida incurável" (p. 13, "Marcas do abandono"). Essas primeiras interpretações de seu próprio relato não deixam dúvida quanto à (re) invenção de uma infância sofrida, vivida sob a opressão de um pai "cachacento", violento (agredia a esposa e os filhos), aparentemente insensível e nada afetuoso - o negativo da imagem idealizada e desejada do pai protetor e modelar. O dramático relato de Trevisan destaca, então, entre os autobiografemas da retórica autobiográfica, a infância, várias vezes metaforizada como "exílio" de si mesmo, marcada por experiências de humilhação e machucamento, grande parte das vezes infligidos pelo próprio pai; a história da família, de modo a compreender o comportamento do pai; o chamado romance familiar, ou seja a caracterização do pai e da mãe, figuras centrais para a formação do homem, do cidadão e do escritor João Silvério Trevisan. A mãe, embora semianalfabeta, foi quem lhe "deu a literatura de presente" (p. 36, "A bênção da mãe"), oferecendo-lhe livros que abriram caminho para a sua imaginação. Neste sentido, a mãe é a mentora aquela pessoa que, nas autobiografias de escritores, propicia a leitura e o destaque do ato de ler, outro autobiografema relevante - , além de ser a responsável pelo precário equilíbrio da família. Quanto ao pai, José Trevisan, ele divide com o narrador o protagonismo da narrativa, uma vez que o autor escreve para ele, por causa dele, "contra" ele e, gradativamente, "a favor" dele. Acompanhemos as palavras do narrador: "[...] esta será uma conversa de homem pra homem, entre mim e meu pai. Ele terá que ouvir. Tudo. Em todos os lugares onde 
estiver" (p. 9, "Abrindo o jogo", grifos nossos); "Meu pai me abriu caminho para ser quem sou, e aqui estou escrevendo por sua causa" (p. 7, "Abrindo o jogo", grifos nossos); "Não sei o que mais chocou: meu pai que ria de mim ou que não me defendeu. Por que, ao invés de cumprir seu papel protetor, ele achou graça no seu pequeno filho bebendo mijo e sendo escarnecido publicamente? Em situações assim eu não conseguia evitar a certeza de ter como pai alguém próximo de um carrasco" (p. 57, "Inocência violada”).

A ideia de que o autor/narrador escreve "a favor" de seu pai - ou seja, na tentativa de decifrá-lo, de elaborar o seu retrato, de compreendê-lo - começa a se mostrar de forma dispersa, aqui e ali, como no segmento "Histórias da intimidade paterna":

Para José Trevisan, estar vivo talvez assustasse muito. Como diria o poema de Carlos Drummond de Andrade, foi educado para o medo. Passou a vida em meio aos tijolos de medo, levantando casas de medo dentro de si. Seu medo produziu tanta coisa medrosa. Inclusive filhos como eu. Sua existência foi um longo aprendizado no medo. [...]. E me passou esse legado macabro de dançar o baile do medo enquanto se vive. Não sei se existe esperança possível numa tal dança (Trevisan, 2017, p. 19).

À medida que a narrativa avança, ultrapassando a meninice e atravessando o período em que o jovem, para fugir à opressão paterna, vai para o seminário de São Carlos, as experiências se ampliam, e o relato se abre para novas vivências e aprendizados. A narrativa ganha um caráter documental, focalizando a formação religiosa dos seminários interioranos, a mentalidade renovadora do Concílio Ecumênico Vaticano II (que se refletiu na modernização pedagógica do seminário de São Carlos), o opressivo ensino de Filosofia no seminário de Aparecida; o contato enriquecedor com Paulo 
Emílio Salles Gomes, já em São Paulo, entre outras experiências do adolescente. Sobre essa etapa de sua formação, diz o narrador:

Ainda que a duras penas, a adolescência foi me proporcionando evoluções necessárias para meu processo de autoafirmação. Eu já sentia mais segurança de estar no mundo. Tornei-me um líder no seminário. E, em toda parte, dava asas à minha curiosidade intelectual. Entre as tantas transformações, passei a sentir vergonha do meu pai. Foi uma mudança de sentimento significativa. Minha personalidade em desenvolvimento deixava o papel de vítima para um estágio de certo modo superior. Eu desenvolvera musculatura suficiente para desprezar quem tinha me maltratado e abandonado. José Trevisan tornou-se um peso na minha história (Trevisan, 2017, p. 113, “A queda”).

Não seria possível dar conta, neste ensaio, de outros momentos da trajetória do autor, na busca de apaziguamento existencial e do êxito na sua carreira como escritor. Vale destacar que, até os últimos segmentos do livro, os embates com o pai e com a própria condição de homossexual convulsionam a narrativa, que se mantém dilacerada e tensa até as últimas páginas. O que estas últimas páginas trazem de novo são diferentes inflexões na relação com o pai, que incluem não apenas a compreensão, mas o perdão. Tanto que, no segmento "Céus em epifania", o narrador pode dizer: "Este é, com certeza, um livro de perdões. E perdões são inesgotáveis. Em minha velhice, compreendi a urgência de perdoar incessantemente, repetidamente. [...] Perdoei meu pai em muitas ocasiões [...]" (Trevisan, 2017, p. 229). Significativo é também o segmento "Invocação ao perdão", elaborado como uma espécie de oração, e que exibe a autoimagem do autobiógrafo como aquele que percorreu um longo caminho até o gesto redentor do perdão: 
Pai:

Que sempre esteve no meu horizonte como um lixo a ser varrido. $[. .$.

A quem tratei como bode expiatório das minhas desgraças. [...]

Cuja dor sempre foi por mim ignorada.

Pai, que me ensinou tantas coisas em sua suposta ignorância. $[\ldots]$

Peço teu perdão, meu pai (Trevisan, 2017, p. 233).

Se, a respeito do livro Pai, pai, o próprio autor afirmou: “[...] é sim um livro autobiográfico, e eu quis [...] rasgar e exibir o caos da minha alma" (Trevisan, 2018, p. 7) - depoimento corroborado pela breve análise aqui empreendida -, o livro $O$ conto zero e outras histórias elabora sob outro viés a matéria autobiográfica, dispersando-a e entrelaçando-a mais frequentemente na urdidura ficcional. Entretanto, elementos da retórica autobiográfica ali também se fazem sentir, embora fragmentariamente, como a ficcionalização da infância, a encenação do romance familiar, a figuração dos lugares da memória, a formação escolar, entre outras.

Dando exemplo da riqueza, variedade e inventividade das formas e estratégias textuais que a escrita autobiográfica tem assumido na contemporaneidade, as duas obras - O conto zero e Pai, pai têm em comum a densidade existencial que as caracteriza, efeito de uma linguagem e de uma composição refinadas e inventivas. 


\section{Referências}

CANDIDO, Antonio. "Poesia e ficção na autobiografia”. In A educação pela noite \& outros ensaios. São Paulo: Ática, 1987, pp. 51-69.

GASPARINI, Philippe. Est-il je? Roman autobiographique et autoficcion. Paris: Éditions du Seuil, 2004.

LEJEUNE, Philippe. O pacto autobiográfico: de Rousseau à internet. Belo Horizonte: Editora UFMG, 2008.

MOLLOY, Sylvia. Vale o escrito: a escrita autobiográfica na América Hispânica. Chapecó: Argos, 2003.

PRIORY, Mary del. "Prefácio". In REZENDE, Francisco de Paula Ferreira de. Minhas recordações. 2 ed. Rio de Janeiro: Topbooks, 2015, pp. 21-6.

REZENDE, Francisco de Paula Ferreira de. Minhas recordações. 2 ed. RJ: Topbooks, 2015.

SANT'ANNA, Sergio. O conto zero e outras histórias. São Paulo: Companhia das Letras, 2016.

Anjo noturno: narrativas. São Paulo: Companhia das Letras, 2017.

TREVISAN, João Silvério. Pai, pai. Rio de Janeiro: Alfaguara, 2017.

. Rascunho. Entrevista concedida a Rodrigo Casarin, abr. 2018, pp. 6-7.

ZAGURY, Eliane. A escrita do eu. Rio de Janeiro: Civilização Brasileira; Brasília: INL, 1982. 
Giovanna Dealtry

Ruas, quartos, janelas: Manuel Bandeira espia 
Começo esta reflexão sobre Manuel Bandeira e o Modernismo chamando à cena um de seus melhores amigos, o poeta e escritor Ribeiro Couto. Hoje, praticamente esquecido, Couto teve um papel de destaque na transição para o Modernismo, em especial, quando se muda de São Paulo para o Rio de Janeiro, e trava contato com Manuel Bandeira. Em 1920, o poeta pernambucano muda-se para o Curvelo, em Santa Teresa, onde Couto já morava. Como o próprio Bandeira relata em sua biografia literária, Itinerário de Pasárgada, "foi por intermédio dele que tomei contato com a nova geração literária do Rio e de São Paulo, aqui com Ronald de Carvalho, Álvaro Moreyra, Di Cavalcanti, em São Paulo, com os dois Andrades [...].” (Bandeira, 2012, p. 83). Em seguida, Bandeira declara que, quando Mário de Andrade esteve no Rio para ler na casa de Ronald de Carvalho e na de Olegário Mariano a inédita Paulicéia Desvairada, "eu já estava bem preparado para receber de boa cara os desvairismos de Mário, porque Ribeiro Couto, era um 'grande farejador de novidades' da Itália, Espanha e Hispano-América”.

O círculo de boêmios intelectuais seria ainda acrescido por nomes como Jaime Ovalle, Sérgio Buarque de Hollanda, Rodrigo Mello Franco de Andrade, Dante Milano, Geraldo Barrosos do Ama- 
ral, entre outros. Cada um desses homens, a seu modo, estava propondo caminhos para o Brasil modernista. Nesse sentido, o pensar modernista carioca passava invariavelmente pelo caminho das ruas e da cultura popular.

O conto "Endereço de Tia Ciata" (1935), de Ribeiro Couto, pode ser lido como um registro desse momento peculiar do modernismo carioca quando a tradição literária se vê invadida por aspectos e personagens da cultura popular que irão subverter a ordem e mudar os parâmetros da composição poética. Dominam o conto a musicalidade e a temática afro-brasileira de alguns poemas de Bandeira colocados em tensão constante com a tradição conservadora. O personagem central é José Elezeário Gomes, crítico literário e funcionário público. Em relação à sua primeira atividade, tem posição categórica: “- Sou pelas Boas Tradições do Verso”. Imagine-se, pois, o espanto quando José Elezeário recebe um exemplar autografado do livro de Manuel Bandeira, Libertinagem, publicado em 1930.

Trancou na gaveta o livro secreto, mas não conseguiu escapar ao atordoamento provocado por aqueles 'pseudos-versos'. Até que um dia, como que emperrando em um obstáculo sub-consciente, passou a repetir:

- Sambas de tia Ciata,

Cadê mais a tia Ciata,

Talvez em Dona Clara meu branco,

Ensaiando cheganças p’ra o Natal (Couto, 1935, p.

174).

No poema "Mangue", Bandeira traz para a poesia o cotidiano das ruas esquecidas do Rio, da mesma forma em que se nutre das formas, ritmos, musicalidades próprias ao universo afro-brasileiro. José Elezeário torna-se então obcecado pelos versos e pela própria 
Tia Ciata. Libertinagem o havia enfeitiçado. "Sobretudo aquele pseudo-poema da página 31, e sobretudo a misteriosa atmosfera criada pelo dito pseudo-poema" (p.172).

O feitiço dá-se através da fala, não mais da fala primeira do feiticeiro negro, mas do feiticeiro branco Bandeira contaminado em definitivo pela junção entre palavra cantada e música, própria às liturgias de matrizes africanas. Diante do encanto nem branco nem negro somente, mas também branco e também negro, o defensor das boas tradições do verso teima em proteger seus princípios que até então pareciam inabaláveis. O "outro", representado por Tia Ciata, o toma duplamente: como revolução poética e forte presença musical. O corpo do pobre José Elezeário não suporta essa invasão.

José Elezeário torna-se "cavalo"1 de Bandeira, ou de Tia Ciata falando por Bandeira. $\mathrm{O}$ funcionário público transforma os versos em assobios, cantoria, música de feitiçaria e passa a perseguir esse fantasma de mulher, emblema da cultura afro-brasileira. Inúteis tentativas do crítico de compreender e delimitar os versos de Bandeira ou encontrar o endereço de Tia Ciata. Encontrar tais respostas onde mora Tia Ciata?, o que são aqueles versos? - implicaria uma redefinição do próprio lugar de fala do crítico literário tradicionalista.

Nesta nova ordem, construída pela modernidade, o intelectual passa a valorizar compositores populares, integrantes dos candomblés, marginais, como narradores de suas próprias contranarrativas não oficiais. Ou se rompe com a tradição dos bons versos e da boa cultura, ou se sucumbe diante do inevitável.

\footnotetext{
1 O termo "cavalo" aplica-se aos sujeitos que durante os ritos do Candomblé incorporam os orixás.
} 
Ribeiro Couto (1935, p. 180) traça de maneira fatalista o destino de homens como José Elezeário Gomes.

À distância, o Maravilhoso fizera efeito. Tia Ciata e os demais fluídos líricos perseguiam José Elezeário Gomes. O Defensor Perpétuo das Boas Tradições do Verso consumia-se, cada dia um pouco, com todos os seus Pontos de Vista. Uma noite, sangue de José Elezeário Gomes virou água. D. Candoquinhas foi ver, estava morto.

Tia Ciata, "Manu" Bandeira, a fala errada do povo, o canto africano, "os novos fluídos líricos" modernistas terminam por suplantar a defesa conservadora da poesia. Como na "Macumba do Pai Zusé", também de Libertinagem, o Rio de Janeiro se contamina apesar das distâncias e das diferenças sociais. Mandinga do Encantado e de Tia Ciata invadindo os territórios de resistência da cidade.

$\mathrm{Na}$ macumba do Encantado

Nego véio pai de santo fez mandinga

No palacete de Botafogo

Sangue de branca virou água

Foram vê estava morta!

Em Itinerário de Pasárgada, Bandeira afirma que Libertinagem teria nascido da convivência quase diária com ilustres boêmios como Jaime Ovale, Dante Milano, Osvaldo Costa e Geraldo Barroso do Amaral. Poemas como "Mangue", "Macumba do Pai Zusé", "Noturno da Lapa" e "Na boca" "seriam resultado da convivência do grupo entre si e da comunhão com a cidade". O antológico "Noturno na Lapa", ainda segundo o poeta, foi aproveitado de um caso vivenciado por Ovale quando este morava na Rua Conde Lage.

Nos poemas de Bandeira, os lugares nomeados do Rio de Janeiro são, simultaneamente, tratados como espaços geográficos, remetendo o leitor ao presente da cidade ocupada pelas camadas marginalizadas, e também narrativizados, corroendo as fronteiras 
de classe, raça e cultura, transformando a poesia modernista em território livre de idas e vindas, entre o centro e as margens.

Na poesia de Bandeira vemos a intersecção entre bairros, ruas, terreiros de candomblé, cafés, em suma, a rua, e as próprias moradas de Bandeira na cidade. A rua torna-se campo de observação e aprendizagem, ainda mais quando consideramos a importância do olhar e da escuta na poesia do poeta.

A rua do Curvelo ensinou-me muitas coisas. Couto foi avisada testemunha disso e sabe que o elemento de humilde quotidiano que começou a se fazer sentir desde então em minha poesia não resultava de nenhuma intenção modernista. Resultou, muito simplesmente, do ambiente do Morro do Curvelo. Disse-o Couto melhor do que eu mesmo poderia explicar agora: 'Das vossas amplas janelas, tanto as do lado da rua em que brincavam crianças, como as do lado da ribanceira, com cantigas de mulheres pobres lavando roupa nas tinas de barrela, começastes a ver muitas coisas. $\mathrm{O}$ morro do Curvelo, em seu devido tempo, trouxe-vos aquilo que a leitura dos grandes livros da humanidade não pode substituir: a rua.' (Bandeira, 2012, p. 82).

Se Libertinagem, composto na sua totalidade no Curvelo, assim como Ritmo Dissoluto e Crônicas da província do Brasil, surge como o livro que marca a maturidade modernista de Bandeira, seja pela adoção da diversidade rítmica, dos versos livres, e, em especial, pela inclusão da cidade polifônica à matéria poética, é também certo afirmar que o espaço da rua já estava presente na formação do poeta desde a infância, quando este se dá conta que "A vida não me chegava pelos jornais nem pelos livros/Vinha da boca do povo na língua errada do povo/Língua certa do povo/Porque ele é que fala gostoso o português do Brasil/Ao passo que nós/O que fazemos/É macaquear/A sintaxe lusíada [...]" (Evocação ao Recife - 1925). O erro, tantas vezes valorizado pelo Modernismo, assim como a infância, traduz-se aqui pela proximidade com o povo e o falar das ruas, em semelhança ao poema "Na rua do sabão" (Ritmo dissoluto - 1924), 
que se inicia de forma abrupta, como se o canto das crianças invadisse o poema ou o pensamento do poeta. "Cai cai balão/Cai cai balão/ Na rua do Sabão!"

Vemos nas obras escritas no Curvelo, no bairro de Santa Teresa, o estabelecimento definitivo do vínculo entre rua e linguagem que encontra no olhar e na poesia de Bandeira sua mediação. É desse lugar de mediador - entre a herança letrada de base europeia e a sedução imperativa do quotidiano humilde das ruas - que Bandeira nos fala. Como a mandinga do Encantado, a poética bandeiriana religa, contamina, os espaços físicos e simbólicos da cidade, a partir da cultura, em especial, das classes populares.

Nos anos 1930, Bandeira colabora assiduamente para revistas literárias e a grande imprensa. No volume Crônicas da província do Brasil, de 1937, estão reunidos textos publicados nos jornais A província, de Recife, Diário Nacional, de São Paulo, e O Estado de Minas, de Belo Horizonte, além das revistas Souza Cruz e Boletim de Ariel.

Encontramos nestes escritos um "provinciano" que, à semelhança da caravana paulista que segue com Blaise Cendras às cidades históricas de Minas Gerais, também irá descobrir o Brasil através das viagens. Como observa Francisco de Assis Barbosa, se Bandeira já conhecera inúmeras cidades brasileiras em busca do clima apropriado aos seus problemas de saúde, "foi com o modernismo que passou a sentir o Brasil" e sua "iniciação nativista” é acompanhada e guiada de perto por Mário de Andrade.

Assim, em carta de 02 de fevereiro de 1928 escrita a Mário de Andrade, Bandeira fala dos planos de viagem, ao lado de outro "provinciano", conhecedor do Brasil.

O Gilberto (Freyre) está assanhado pra fazer uma viagem comigo às velhas cidades mineiras que nem eu nem ele conhecemos. É provável que a ideia pegue. Iremos a São João d'El Rei, Ouro Preto, Mariana, Congonhas, Sabará [...] Se você tem algum conselho ou sugestão a fazer me escreva logo, porque 
é possível que partamos a 10 dias mais ou menos (Bandeira, 2006, pp. 242-3).

As viagens de (re)conhecimento pelo Brasil, de Ouro Preto à Bahia, de Recife aos subúrbios do Rio, cumprem não somente o ideário modernista, mas tornam-se vozes na prosa e na poesia de uma experiência direta da realidade brasileira.

Se "a poesia está nos fatos", conforme sentencia Oswald de Andrade, Bandeira traz os fatos estéticos para o espaço da crônica, por meio de um olhar que nunca se mistura completamente ao "outro". O Rio de Janeiro apesar de não ser o centro oficial do modernismo pós22 torna-se território singular em que a vida da metrópole dissolve as fronteiras com o que há de mais "bárbaro e nosso", nas ruas da cidade, diante do poeta. A proximidade, desejada em manifestos, cartas, romances, com o povo brasileiro, suas vozes, corpos, festas, aqui se revela como imposição cotidiana aos artistas do modernismo. Como fica claro na crônica "Sambistas", publicada em Crônicas da Província do Brasil (1936), em que Bandeira (p. 153) recorda o encontro com Sinhô, em 1920. Sinhô viria a morrer dez anos depois.

Quando morreu o afamado Sinhô, escrevi para o Diário Nacional de São Paulo uma crônica em que recordava com saudade alguns traços curiosos da figura do rei do samba carioca. E contei uma cena a que tive o prazer de assistir em casa dos meus amigos Eugênia e Álvaro Moreyra. Foi o caso que numa das extintas deliciosas quintas-feiras em que o casal recebia, apareceu o Sinhô e regalou os convidados não só com a sua conversação como com os seus sambas. Estava mal de voz, tossia muito (era a velha tuberculose que apertava o cerco), mas nenhum de nós teve a menor ideia de atribuir aquela tosse à terrível moléstia e, como era do mais elementar dever, poupar o doente. O que nos desculpa daquela descaridade é que Sinhô para toda gente era uma criatura fabulosa, vivendo no mundo noturno do samba, zona impossível de localizar com precisão - é no Estácio mas bem perto ficam as macumbas do Encantado, mundo onde a impressão que se tem é que ali o pessoal vive de brisa, cura a tosse com 
álcool e desgraça pouca é bobagem. Assim quando Sinhô parava num acesso, ia-se buscar uma boa lambada de Madeira e o fato é que a tosse passava.

Se o corpo real de Sinhô está ali no espaço da casa dos Moreyra, jornalistas e empresários teatrais, com seu samba e sua tosse, a "criatura fabulosa", originário de uma fábula talvez, habita a zona impossível de localizar com precisão, fronteira entre espaços não somente econômicos, mas especialmente culturais, que não é dado ao observador Bandeira compreender. Por isso, o caráter de excentricidade e, talvez, da impossibilidade de existência concreta do Rei do Samba contaminam o relato afastando do teor documental. Por outro lado, ao transformar Sinhô de sambista em personagem literário da cidade e seus costumes, Bandeira distancia-se da cidade concreta e passa a negociar com a imagem inventada do carioca malandro, da cidade ficcionalizada. A fala, do cronista ou do poeta, situa-se nessa interface, ora roçando a aspereza do real, ora distanciando-se do chão das gentes, voltando o olhar para a distância, como o balãozinho que "...foi subindo.../ muito serenamente.../ para muito longe....

Entre o próximo e a distância, o quarto.

Bandeira irá assumir uma voz discursiva própria no Modernismo brasileiro, somando o falar gostoso do povo à evocação de um eu lírico marcado pela fantasmagoria da morte, permanecendo muitas vezes um observador de fronteira, resguardado em seu quarto suspenso no ar, como lembrado em "Última canção do Beco" (Lira dos cinquent'anos):

Vão demolir esta casa

Mas meu quarto vai ficar,

Não como forma imperfeita

Nesse mundo de aparências: 
Vai ficar na eternidade,

Com seus livros, com seus quadros,

Intacto, suspenso no ar!

O quarto é presença constante na obra de Bandeira. O quarto do tísico, o quarto cuja janela se abre sobre o Curvelo, o quarto de onde espia o beco e a estrela da manhã, quarto onde ao admirar os aviões partindo do Santos Dumont aprende a se despedir também, quarto idealizado a ficar pela eternidade em conversa com o amigo Jaime Ovale. Os quartos reais são muitos - no Curvelo, na Morais e Vale, no Castelo - , ao mesmo tornam-se espaços de intimidade, extensão do eu lírico, cujas fronteiras se desfazem diante do abraço com a cidade.

Na visão de Davi Arrigucci, o quarto na poesia de Bandeira adquire estatuto de microcosmo da interioridade lírica, sem nunca, no entanto, confundir-se com uma "torre de marfim" ou mero refúgio das dores existenciais. Torna-se um "espaço de mediação entre a mais funda interioridade lírica e o mundo exterior, onde se processa uma metamorfose essencial do ponto de vista poético" (1990, p. 63).

Na poética bandeiriana não existe a oposição rígida entre casa/ quarto e rua/cidade. Pelo contrário, são territórios intercambiáveis onde o "eu" torna-se objeto do olhar de si mesmo e do outro. Nessa identificação e atração pelo "outro", o olhar de Bandeira transmutase entre o registro lírico, existencial, social.

"O bicho", sempre relembrado pelo forte impacto da denúncia social do homem transmutado em animal pela fome, foi escrito quando o Bandeira morava no condomínio São Miguel, na Av. Beira-Mar, em apartamento de fundos para o pátio interno. Mesmo quarto, apartamento e pátio capturados pela lente de Joaquim Pedro de Andrade, no curta-metragem O poeta do Castelo (1959). No comovente filme, acompanhamos o dia a dia do poeta nas imagens 
mais comezinhas; o poeta compra leite; o poeta faz café; o poeta deita-se na cama, de pijamas, para digitar seus escritos e rir ao telefone. $\mathrm{O}$ poeta abre a janela.

"Poema só para Jaime Ovalle", "Lua Nova”, "Comentário Musical", "A estrela e o anjo" são alguns dos poemas que fazem referência direta ao espaço físico e a centralidade do quarto no cotidiano do poeta. É um "quarto-eu” invadido por memórias, sons, mundo.

O meu quarto de dormir a cavaleiro da entrada da barra.

Entram por ele dentro

Os ares oceânicos, Maresias atlânticas:

São Paulo de Luanda, Figueira da Foz, praias gaélicas da Irlanda...

(Comentário Musical)

Meu novo quarto virado para o nascente:

meu quarto, de novo a cavaleiro da entrada da barra.

Depois de dez anos de pátio.

Volto a tomar conhecimento da aurora.

Volto a banhar meus olhos no mênstruo incruento das madrugadas.

Todas as manhãs o aeroporto em frente me dá lições de partir. (Lua Nova)

Nessa perspectiva, o quarto não é refúgio, lugar de proteção usual dos rumores da rua. Mas ponto de observação - do fora e do dentro - capaz de dimensionar novas experiências. O pátio, o amanhecer que ignora persianas, as lições de partir. A todas, o poeta se abre.

O quarto torna-se lugar do acolhimento da morte e da meditação, mas também fronteira que se faz a espreitar a vida e o desejo. Assim é que o quarto surge como um espaço de mediação entre o "eu" e a descoberta do "outro", do qual o poeta não foge. O quar- 
tos suspensos de Bandeira assim oferecem novas possibilidades de observação do outro, modeladas pelas esquadrias, pelo limite físico imposto pela separação entre a janela e o rés do chão.

"Noturno da Rua da Lapa" abre-se com a sentença fatídica: "A janela estava aberta". Aberta é a poesia de Bandeira que se deixa atravessar e com isso ser atingido pelo inesperado, pelo insólito que interrompe a reflexão do poeta.

"Não posso atinar no que eu fazia: se meditava, se morria de espanto ou se vinha de muito longe." É nesse momento de suspensão que o poeta é interrompido pelo inseto voador que invade o quarto. A vida que chama. A bomba de flit não adianta. O animal fica cada vez maior. Se o poeta volta-se sobre si mesmo, o inseto "implacável" insiste em atingi-lo em sua forma agigantada. Por isso, mesmo o quarto não é um espaço seguro. A janela aberta é a imagem do imponderável, do incontrolável na obra bandeiriana. Por ali se vê o balão subindo, os aviões partindo, deseja-se a lua nova, mas também, via de mão dupla, revela a fragilidade desse suposto espaço de proteção.

É do quarto suspenso no ar da Lapa, recuperado em "Primeira canção do beco" (Estrela da Tarde - 1960), Bandeira recria esse olhar para a rua de prostitutas e travestis.
Teu corpo dúbio, irresoluto,
De intersexual disputadíssima,
Teu corpo, magro não, enxuto,
Lavado, esfregado, batido
Destilado, asséptico, insípido
E perfeitamente inodoro
É o flagelo de minha vida,
Ó esquizoide! ó leptossômica! 
"Dúbio", "intersexual", não deixam dúvidas quanto a se tratar de uma travesti. Da mesma forma, "enxuto", “insípido", "asséptico”, para apontar para um indivíduo bem jovem. Ao menos, um indivíduo cujo corpo ainda não se constitui como de "fêmea" ou "macho", como indica o termo leptossômica, tratado aqui como um sinal de transtorno.

E é justamente esse corpo, "disputadíssimo", que atrai desesperadamente o poeta. Será que podemos ler esse corpo-desejo não bem visto pela sociedade como o enorme inseto de "Noturno da rua da Lapa" a quem a bomba de flint, o desejo de morte, só o faz crescer e tomar todo espaço do quarto?

$\mathrm{Na}$ estrofe final, Bandeira ordena a sua interlocutora:

Póe paradeiro a este tormento!

Liberta-me do atroz recalque!

Vem ao meu quarto desolado

Por estas sombras de convento,

E propicia aos meus sentidos

Atônitos, horrorizados

A folha-morta, o parafuso,

O trauma, o estupor, o decúbito!

O quarto, situado entre lupanares e o Convento das Carmelitas, torna-se por fim espaço do encontro sexual ainda que interdito pelas sombras do recalque, do catolicismo. Mas, talvez, agora, o inseto agigantado de "Noturno da rua da Lapa" tenha partido finalmente do quarto, expulso pela condição atônita do poeta diante do próprio desejo. 


\section{Referências}

ARRIGUCI Jr, Davi. Humildade, paixão e morte. A poesia de Manuel Bandeira. São Paulo: Cia das Letras, 1990.

COUTO, Ribeiro. “Endereço de Tia Ciata”. In Conversa Inocente. Rio de Janeiro: Schmidt, 1935, pp. 171-82.

BANDEIRA, Manuel. Crônicas da província do Brasil. São Paulo: Cosac Naify, 2006.

_. Estrela da Vida Inteira. 20 ed. Rio de Janeiro: Nova Fronteira, 1993.

. Itinerário de Pasárgada. São Paulo: Global, 2012. 
Italo Moriconi

Hilda Hilst: passos da consagração 
Redescobrir, revisitar Hilda Hilst traz os prazeres de explorar os meandros e ampliar a visão de uma obra completa, vocacionada à consagração no cânone literário, ao mesmo tempo capaz de alimentar hoje projetos de ponta não só na literatura, mas também no teatro, performance e outras áreas artísticas. Na poesia, Hilda foi uma não modernista, porém moderníssima. Na prosa, uma exploradora dos limites da sintaxe e da representação literária do sujeito. Na sátira erótica, é para ser igualada ao que há de melhor no gênero em língua portuguesa, num clube de muitos varões, antigos e contemporâneos, héteros e gays, de Gregório de Matos a Bernardo Guimarães, de Glauco Mattoso a Valdo Mota.

Moderna, porque apesar de trabalhar no espaço do poema convencional, com seus versos e estrofes, o faz de maneira livre, sem a rigidez da métrica nem o esquematismo das rimas. Seu vocabulário vem do coloquial moderno, mas o tom assumido por sua voz, solene, situa sua poesia no campo do discurso elevado, em contraste com as propostas dominantes no legado dos modernismos dos anos 20 e 30. Assumir o caráter solene da palavra poética estava em consonância com o momento literário em que Hilda estreou, na virada dos anos 40/50. Naquele momento, a poesia brasileira girava rumo 
ao sério e ao nobre - mestres como Drummond, Murilo Mendes, mesmo Bandeira, evoluíam para formas clássicas e temáticas mais reflexivas, de certo modo nostálgicas e históricas.

O histórico nunca foi exatamente a praia poética de Hilda Hilst. A contrapelo, sua poesia se propôs estar de corpo inteiro dentro daquilo que o modernismo hegemônico deixara de fora, o lirismo amoroso, gênero imemorial de arrebatamento passional. Nesse terreno, só interessa no poema a história de uma paixão. O poema é inscrição resíduo reflexivo dessa experiência. Não tem poema piada nem poema brejeiro. Ao longo, porém, de sua extensa trajetória, o fazer poético de Hilda vai se desdobrando em etapas, veredas que revelam as quebras, os limites, as ironias, os paradoxos do dizer de paixão.

Paixão sempre carnal, pulsando para ser corpo para o homem, mantendo, porém, em última instância, cruel distanciamento em relação ao macho. No núcleo de cada paixão, vivida na vida real e poetizada no livro de versos, vibra a lucidez indômita do poeta. $\mathrm{O}$ poeta: aquele que se destaca do cotidiano e profere sua palavra-inscrição. Na poesia de Hilda, a persona de poeta, suporte de todas as máscaras, é do gênero neutro, declinado no masculino por imposição da gramática. Entre o vivido e o dito, a gramática se faz corpo. Carnadura do verbo. Vivenciar a paixão, o amor, o desejo, é vivenciar o limite entre o masculino e o feminino.

Descolamento. A vida e a obra de Hilda Hilst são marcadas por um deslocamento decisivo, ocorrido no curto espaço de tempo que vai do ano de 1966, quando a poeta se muda para a Casa do Sol, até 1970, quando publica pela Perspectiva seu primeiro livro em prosa - Fluxo-floema, com prefácio de Anatol Rosenfeld. Muito tem 
sido dito e pode ser ainda pesquisado sobre o lugar e o tempo em que ocorre a mutação por que passa Hilda. A Casa do Sol ainda precisa ter detalhada sua história como cenáculo da vida literária paulista durante pelo menos duas décadas. ${ }^{1}$ Algo transparece nos relatos e cartas que já temos da relação entre Hilda e Caio Fernando Abreu. Testemunham o momento em que ambos elaboravam de maneira muito consciente seus projetos. Agora a publicação das cartas entre Hilda e José Luís Mora Fuentes dá novo fôlego aos interessados em biografia e vida literária.

Tendo abandonado a vida social mundana (mas não a vida social entre amigos), Hilda opta por levar uma "vida de escritor". Um passo corajoso. Não se tratava de vida de escritora apenas ou principalmente no sentido profissional da palavra. Era vida de escritor no sentido existencial, visceral. Era a viagem à roda do quarto, ou à roda do pátio, tendo o mundo e todas as esferas cósmicas e telúricas à mão através dos livros. Hilda dedica-se disciplinadamente à leitura e escrita, alheia a encomendas ou adiantamentos editoriais.

Vida de escritor: ter tempo para escrever. Como indicaram recentemente depoimentos de Jurandy Valença e Olga Bilenky, em evento pré-FLIP sobre Hilda no SESC Rio Flamengo, "ter tempo para escrever" era uma questão central para Hilda, foi mesmo a moeda que ela ofereceu a Jurandy para mantê-lo perto de si. “Ter tempo para escrever" é certamente o principal motivo de quem opta por vida de escritor. Pode ser o nó inextricável de uma angústia de vida, como no caso de um João Gilberto Noll. Mas é também uma grande conquista para quem consegue. A Hilda desse final de anos 60 triunfava. Agarrou seu tempo e não pretendia jogá-lo fora. Tarefa para os cronistas da vida literária é desvendar os bastidores financei-

1 Vale mencionar aqui a tese de doutorado de Fernanda Schcolnik (UERJ, 2016). 
ros de uma vida de escritor. O voto de dedicação à escrita é, de certo modo, voto de pobreza inexorável. Hilda teve a sorte de, a partir de certo ponto, contar com a bolsa de escritora residente da Unicamp. Quiséramos nós que mais programas de escritor residente pudessem ser bancados por nossas universidades.

Em seu novo habitat, no período mencionado, fins dos anos 60 , Hilda escreve oito peças de teatro, gênero ao qual nunca mais voltará. Somos tentados a encará-las como exercícios em que a escritora artista treinava a mão. Mas elas tiveram uma presença em seu tempo e O Verdugo ganhou o Prêmio Anchieta em 1969. Hoje uma nova geração de leitores se interessa por essa produção, que está sendo republicada pela LP\&M. Porém, como no caso de Caio Fernando, atualmente a maioria das montagens de textos de Hilda é adaptação de sua prosa.

O que Hilda queria era ir além do gênero poesia. Não abandoná-lo, como não abandonou, mas encontrar um modo de criação que rompesse as amarras do verso, da forma acabada, da gramática. Era o desbunde na vida e na arte. Sua opção final foi a prosa de ficção. Ao pulverizar a voz narrativa, encontrou a solução para a dramaticidade desejada, levando-a para dentro da prosa. Essa pulverização foi conseguida, foi urdida enquanto pensava nos dilemas e possibilidades da escrita narrativa àquela altura. Ela viu que empreender o mergulho na prosa exigia situar-se diante do estado da arte do conto, da novela, do romance, na literatura universal.

Decididamente, ela não seria apenas uma contadora de histórias. A meta era a escrita. Sem deixar de lado a fabulação, seu texto irá narrar a experiência mesma de escrever. É a épica do narrar mais que a épica (ou antiépica, na clave moderna) do narrado. Já no pór- 
tico de Fluxo-floema, a autora deixava claro seu ponto de partida, que na verdade era o ponto de chegada de suas reflexões críticas. Se a escrita ficcional tinha sido revolucionada pelo fluxo de consciência, era preciso dar um passo à frente, assegurar uma linha evolutiva. $\mathrm{O}$ referente imediato já não podia mais ser Joyce ou Virginia Woolf, e sim o Beckett da trilogia Molloy, Malone Dies e The Unnamable. Devemos considerar a epígrafe de Fluxo-floema, extraída de Molloy, como uma síntese perfeita do projeto de escrita a que chega Hilda. Vale reler: Havia em suma três, não, quatro Molloys. $O$ das minhas entranhas, a caricatura que eu fazia desse, o de Gaber e o que, em carne e osso, em algum lugar esperava por mim. [...] Havia outros evidentemente. Mas fiquemos por aqui, se não se importam, no nosso circulozinho de iniciados.

É no terreno beckettiano da pulverização do sujeito narrador, incorporando o tom sarcástico da caricatura de si, que se situa toda a obra ficcional de Hilda Hilst, com exceção dos textos ditos pornográficos dos anos 90, cuja referência será outra, embora sua irrupção na obra seja coerente com os traços de obscenidade que se foram afirmando, insistentes, na prosa hilstiana, depois do inaugural Fluxo-floema. A este seguiu-se a publicação, em 1977, de Ficções, uma coletânea que agregava ao primeiro livro os textos de Pequenos discursos. E um grande e uma narrativa de 1973, Quadós, depois rebatizada como Kadosh, por determinação da própria Hilda, como nos relata Alcir Pécora, coordenador da publicação da obra completa pela Globo. Temos agora nova editora, a obra completa em prosa reunida num único volume pela Cia das Letras, depois de ter lançado a poesia completa em 2017. São passos da consagração póstuma. 
Se na poesia Hilda permanece nos limites de gênero, na prosa ela já se coloca de saída no campo da indistinção ou superação dos gêneros - através do conceito e da prática da escrita, a "écriture" de Roland Barthes, o texto "escrevível" por um leitor engajado, enredado. A prosa em fluxo, num estágio de desagregação. Em 1977, quando Edições Quíron lança Ficções, nos postos mais avançados da produção literária termos como conto ou romance já não fazem sentido prático. É a época das "ficções" de Borges, da revista francesa Tel Quel, do foco da crítica universitária no "texto", no "discurso". A prosa-fluxo de Hilda tem seu andamento de poema, se quer floema, seiva - mais ritmo que estrutura, a própria poesia entra nela, dando às vezes um aspecto de miscelânea.

A pulverização das figuras, das máscaras, dos sujeitos, confere dramaticidade vertiginosa ao discurso. Por trás dos causos, cenas, situações narradas, prevalece o fio condutor, o fluxo-floema da indagação do sentido do escrever, uma indagação existencial, um fio que se desfia de frase a frase, de grumo a grumo de significado. O sentido do escrever é a busca do sentido maior. O sentido da vida. Básico assim, até um pouco subliterário. A figura de Deus, de chofre, visada, desejada, invocada, profanada. Deus prolifera em deuses, daimons, animalidade. É pela metáfora e pela blasfêmia que o sentido pode ser aproximado. Deus é um atrator do discurso.

Depois de Ficções, a desagregação do narrar, de extração beckettiana, vai adquirindo pelas mãos de Hilda o que se pode talvez denominar uma "erótica do relaxo" que, no limite, se transmuda no "escracho" de sua face pornô, como assinalou Eliane Robert Moraes. Um texto como A obscena Sra. D fornece possível chave para essa conversão. A erótica do relaxo dissolve a ética no ceticismo das materialidades, das animalidades. No centro de tudo, vibra a paixão avassaladora da narradora pela figura do pai (o Pai), de deus (o 
Deus). A desagregação do sujeito é na verdade desagregação do feminino. Mulher: amante, mãe desnaturada, velha repelida. Do relaxo da miscelânea discursiva na face obscena ao escracho da promiscuidade na face pornográfica, eis os dois lados do trabalho de prosadora de Hilda Hilst na fase dos anos 90.

O ceticismo povoado de euforia e abjeção redunda num estado de bufoneria universal, humor e deboche como princípios fundantes, reveladores do impasse intransponível do Sentido. No caso de Hilda Hilst, essa bufoneria, enquanto ponto de vista filosófico, é "transcedental", na medida em que constitui condição sine qua non para a existência do espírito (o intelecto). Mas é também imanente, pois ancorada em nosso corpo e nas materialidades comezinhas e patéticas que nos afetam e que afetamos. O grand finale bufólico da obra, obrar. Bufônico e alcóolico. (São de 1990 os poemas de Alcoólicas - “a vida é líquida!”). 


\section{Referências}

HILST, Hilda. Da Poesia. S. Paulo: Cia das Letras, 2017.

. Da Prosa. S. Paulo: Cia das Letras, 2018.

MORAES, Eliane Robert. "Da medida estilhaçada". In Cadernos de Literatura Brasileira, Instituto Moreira Sales, 1999.

REGUEIRA, Nilze Maria de A. e BUSATO, Susana (orgs.). Em torno de Hilda Hilst. S. Paulo: ed. Unesp, 2015.

SCHCOLNIK, Fernanda. Nos rastros do arquivo, as formas autorais de Hilda Hilst (tese). Rio de Janeiro, UERJ, 2016. 
Leonardo Davino de Oliveira

Crônicas, cantos e outras críticas do sujeito cancional 
Desde que a canção popular urbana tomou para si a missão de cantar o Brasil para o Brasil, e isso se afirma enquanto projeto coletivo e sistemático exatamente no momento em que as forças de repressão e censura avançam pela década de 1960, apresentar cronisticamente a realidade sociopolítica brasileira passou a ser um eixo temático incontornável, com o cancionista assumindo muitas vezes o lugar de intelectual da cultura.

Neste meio século dos Festivais da Canção e da Tropicália, este ensaio apresenta uma leitura justaposta de duas canções emblemáticas do período: "Alegria, alegria" de Caetano Veloso - 4 lugar no III Festival da Música Popular Brasileira (1967), TV Record; e "Pra não dizer que não falei das flores" de Geraldo Vandré - $2^{\circ}$ lugar no III Festival Internacional da Canção Popular (1968), TV Globo.

Opero com uma concepção mais ampla de crônica, que permite entender a atuação dos cancionistas como críticos dos variados e complexos aspectos da vida: do engajamento ao desbunde, do político ao banal. O caráter cronístico, que dá conta de acontecimentos contextuais, caracteriza muitas da chamada "canção de protesto" do período observado, em especial entre 1964 e 1968, o que exigirá dos cancionistas certos malabarismos semânticos e formais, a fim de fu- 
gir da censura imposta pela Ditadura Militar. A crônica desliza dos jornais para o corpo, para a voz desses cantores intelectuais críticos da situação do estado de coisas no Brasil.

Originariamente, de vida curta, a crônica se eterniza na memória afetiva dos ouvintes de canção popular e frequentadores dos icônicos Festivais da Canção que marcam a época e definem o gosto cancional do brasileiro de classe média e universitária, e que tem por objetivo a conscientização das massas e a formação de um novo público consumidor. "A morte, o destino, tudo, a morte e o destino, tudo / Estava fora do lugar, eu vivo pra consertar", canta o sujeito de "Disparada" (1966), de Théo de Barros e Geraldo Vandré. Retorna aqui o que Antônio Cândido, em seu artigo "A vida ao rés-do-chão" (2003), identificou como sendo a relação de proximidade estabelecida entre o cronista e o leitor. Ou o ouvinte, no caso de canções cronísticas, empenhadas em ajudar a estabelecer ou restabelecer a dimensão das coisas e das pessoas. A validade da crônica, assim, é estendida e ressignificada afetivamente para o tempo enquanto duram os temas urgentes presentes no plano discursivo dessas canções reflexivas, servindo, igual ao caso da canção "Pra não dizer que não falei das flores", à mobilização e comoção coletiva: das passeatas estudantis de 1977 à campanha pelas Diretas já (1984), passando pelos enterros de vítimas da Ditadura Militar, em destaque: o jornalista Vladimir Herzog (1975) e o operário Santo Dias da Silva (1979).

A distância de postura entre os sujeitos cancionais de cada canção aparece expressa desde os primeiros versos. Enquanto o sujeito da canção de Caetano Veloso canta um "caminhando" contrário ao que o vento, o espírito do tempo (zeitgeist) exige, a saber, o engajamento político do indivíduo nas lutas sociais, o sujeito da canção de Geraldo Vandré convoca o "povo" para seguir essa canção (esse ar) da época. "Olha que a vida tão linda se perde em tristezas assim / 
Desce o teu rancho cantando essa tua esperança sem fim / Deixa que a tua certeza se faça do povo a canção / Pra que teu povo cantando teu canto / Ele não seja em vão", canta o sujeito de "Porta-estandarte", de Geraldo Vandré e Fernando Lona, em uníssono com o sujeito de "Caminhando".

Se canção é sopro, é ar, o sujeito da canção "Pra não dizer que não falei das flores" convida ao canto coral, crente de que o empenho deve estar no coletivo, nas passeatas que reuniam jovens exigindo mudanças nas estruturas antigas de nosso sistema político. Sublinhe-se que Vandré mais tarde iria rejeitar os usos políticos de sua canção, afirmando que menos do que uma "música de protesto", "Caminhando" seria uma "canção de amor", no máximo, "crônica da realidade", "canção expiatória", "música de angústia" (Nuzzi, 2016).

Fato é que desde o título o sujeito de "Caminhando", ao se referir às "flores", está, por metonímia, evocando os desbundados, marginais, alienados adeptos do slogan "paz e amor", e que, dirá o sujeito mais adiante, "acreditam nas flores vencendo o canhão". Lembremos que a imagem do hippie estadunidense serviu de modelo para a dicionarização do desbundado entre nós: cabelos longos, roupas largas, uma flor em uma das mãos e o símbolo "paz e amor" na outra mão. Seria um gesto do cantor "engajado" convocando os "alienados" para juntarem-se em canto? Mais adiante o mesmo sujeito convocará os "soldados armados, amados ou não" a também compor esse coro empenhado num país melhor. Ao resguardar-se na afirmação "pra não dizer que não falei das flores", o sujeito antecipa-se a qualquer acusação futura de descaso para com os desbundados.

O sujeito de "Alegria, alegria" canta o presente imanente e constituinte em contraposição ao desejo de futuro, transcendente, ordenador (externo e superior). Nesse sentido, enquanto o sujeito de Vandré convida, o sujeito de "Alegria, alegria" vai fazendo, ex- 
perimentando. Ambos em suas formas contínuas: "Caminhando...". Um buscando a união, a conjunção pelas semelhanças no desejo de futuro melhor, o outro se despojando de valores antigos de controle da identidade social.

O sujeito de Caetano está na rua, é nômade e não se furta do enfrentamento. Ele adere incondicionalmente ao real e prefere afirmar mais a individualidade, sinônimo de singularidade na multidão, do que ser "massa", facilmente controlada e manipulável. O desbundado se via nessa encruzilhada: mudar o mundo ou "curtir um barato"? Diferente da esquerda armada, os desbundados não pretendiam tomar o poder, ou impor um modelo de sistema melhor. Os desbundados queriam cair fora de todo e qualquer sistema. Nas palavras do cancionista,

desbundar significava deixar-se levar pela bunda, tomando-se aqui como sinédoque para 'corpo' a palavra afro-brasileira que designa essa parte avizinhada das funções excrementícias e do sexo (mas que não se confunde totalmente com aquelas nem com este), sendo uma porção exuberante de carne que, não obstante, guarda apolínea limpeza formal (Veloso, 1997, p. 469).

A fuga pelo misticismo, orientalismo, terapias alternativas, psicologia corporal, sexualidade libertária e ecologia regia a ética dos desbundados. Fuga, nesse caso, é mais o reconhecimento do fracasso das velhas formas de viver e menos uma recusa do enfrentamento dos problemas. Urgia, portanto, enfrentar a patrulha ideológica e liberar a canção e as vozes (a polifonia da multidão), eis a utopia que a Tropicália ousou engendrar.

Os estudantes do TUCA, considerados os mais politizados entre os frequentadores de festivais, não se conformavam que Caetano e Gil não assumissem uma atitude clara de reação ao militarismo e ainda demonstrassem no palco uma certa falta de virilidade que não se coadunava com quem fosse contra a dita- 
dura. A postura máscula de Vandré, um dos ídolos dessa facção, era o oposto (Mello, 2003, p. 277).

Essa Macheza vandreniana simbólica se sustenta em versos como "Meu amor foi embora / Quem é homem não chora / Mas eu vou viver a chorar", de "Quem é homem não chora" (Geraldo Vandré e Vera Brasil); e "O terreiro lá de casa / Não se varre com vassoura / Varre com ponta de sabre / Balas de metralhadora / Quem é homem vem comigo / Quem é mulher fique e chora" ("Cantiga Brava", Geraldo Vandré). Sem esquecer o antológico "Eu venho lá do sertão e posso não lhe agradar / Aprendi a dizer não, ver a morte sem chorar", de "Disparada" (Théo de Barros e Geraldo Vandré).

Ao instar a alteridade, o sujeito tropicalista afirma aquilo que Virgínia Woolf (2014, p. 139), citando Coleridge, inferiu ao pensar que as grandes mentes são andróginas:

É quando ocorre essa fusão que a mente é fertilizada por completo e usa todas as suas faculdades. Talvez uma mente puramente masculina não consiga criar, do mesmo modo que uma mente puramente feminina [...]. [Coleridge] quis dizer, talvez, que a mente andrógina é ressoante e porosa, que transmite emoções sem empecilhos, que é naturalmente criativa, incandescente e indivisa.

Daí que, enquanto "ela pensa em casamento", ele "bebe uma coca-cola e nunca mais foi à escola", reverberando os versos de "O seu amor" (Gilberto Gil), "O seu amor / Ame-o e deixe-o livre para amar / Ir aonde quiser", e desfazendo o coro fascista que dizia "Brasil, ame-o ou deixe-o".

Menos coletivista (povo) e mais mutante (multidão), a mensagem tropicalista calcada no confronto com o espectro do projeto populista autoritário não absolve o ouvinte das responsabilidades diante do processo histórico e sabe que "conduzir" o povo é tarefa dos 
instrumentos do controle do Estado opressor. Ao tropicalista coube compreender a necessidade da iniciativa individual. Por tropicalista entenda-se "aquele que está livre de amarras políticas tradicionais e por isso pode reagir contra a opressão e estreiteza com gestos límpidos e criadores" (Veloso, 1997, p. 319). Sem fé no poder emancipador do "povo" que "caminhando e cantando" segue a canção, o sujeito de "Alegria, alegria" crê na potência da autonomia responsável do indivíduo em meio à multidão.

Ao mesmo tempo, o namoro com o mercado, com a cultura de massa sempre foi o calcanhar de Aquiles da Tropicália. "Ela nem sabe até pensei em cantar na televisão", diz o sujeito de Caetano, confessando para nós ouvintes o desejo inconfessado a "ela", a que faz o sujeito desacelerar o ritmo do caminhar. O desejo de uma arte total, à la Hélio Oiticica, mobiliza o sujeito de "Sem lenço, sem documento" que quer fazer uso da televisão - instrumento de comunicação de massa a serviço da propaganda do golpe militar, e que incomodava bastante determinado setor da esquerda de elite, atenta às reivindicações dos estudantes e operários de então - para propagar as utopias da liberdade e da expressão dos movimentos libertários e contraculturais.

Naquele contexto, tomar uma Coca-cola era uma subversão à lógica da esquerda nacionalista. $\mathrm{O}$ refrigerante imperialista é bebido pelo sujeito que devora as influências estadunidenses na cultura brasileira. Cabe reforçar: o sujeito de "Alegria, alegria", deste modo, “por que não?", nega a mediação e o mediador, seja de direita, seja à esquerda. Ele é representante de si, dono de uma experiência real, autêntica, própria, subjetiva, portanto, excluída da força homogeneizante dos corpos, do condicionamento às estruturas estabelecidas. Ao assumir este caminho não mediado, o sujeito da canção desvencilha-se dos discursos de opressão dos quais a democracia re- 
presentativa parece marcada. Para ele, as desobrigações ideológicas pré-fabricadas e, portanto, também promotoras do empobrecimento da experiência, da redução da experiência a zero, possibilitam a resistência do indivíduo forçado ontologicamente a ser massa, figura vazia de pura obediência. Assim, o que Roberto Schwarz (2012) lê como "apolítico" é, posso arriscar, um gesto radicalmente político e, consequentemente, calcado numa utopia própria das esquerdas, para todos. Vejamos.

$\mathrm{O}$ "sol de quase dezembro", abrasador, desdobra-se na imprensa da contracultura $O$ Sol, jornal de resistência ao golpe militar e que circulou entre setembro de 1967 e janeiro de 1968. O sujeito de "Alegria, alegria" está impregnado das notícias desse jornal, ao mesmo tempo em que se contamina de rua, errância e vagabundagem. Por estar alegre, ele persevera, diz sim à vida, apesar de condenada (contraditória, adversa) pelo contexto político.

Enquanto o sujeito de Vandré canta a restituição da identidade nacional, o outro canta a singularidade de um fragmento da entidade brasileira. Para este não cabe mais restaurar, e sim criar, inventar, engendrar um novo país. Nesse sentido, "Alegria, alegria" percorre o caminho inverso de "Caminhando". Das duas marchas, esta acredita (ingenuamente?) no retorno da segurança pré-golpe e na estabilidade ilusória por vir. "Alegria, alegria", ao contrário, se lança na realidade urbana e múltipla para estilhaçar a confiança nas instituições (Estado e religião), representadas na canção pelo casamento, pela imprensa, pela escola. Aqui o sujeito atravessa a cidade sufocada de "tantas notícias" massacrantes e desestabilizadoras da individualidade, na outra há a crença na igualdade catártica entre as pessoas que serão guiadas pelo sujeito da canção que vive para consertar "a morte, o destino, tudo [que] estava fora do lugar". 
Ao desacreditar, o sujeito da canção de Caetano Veloso, para "seguir vivendo", precisa ir indo; enquanto que o sujeito da canção de Vandré segue crendo no poder aglutinador, amparando-se noutro, delegando ao coletivo as ações que urgem emancipação. Consequentemente, o sujeito de "Alegria, alegria" inventa gestos inapreensíveis pelo sistema paternalista e tirano, colonialista e imperialista. Dito de outro modo era preciso superar o otimismo patriótico, adotando certo pessimismo afirmativo, base da negatividade tropicalista, para que o desmascaramento social e a multiplicidade de dicções e tensões impulsionassem mudanças profundas na motivação de ser brasileiro. Com este projeto de afirmação de uma terceira via, Caetano confundiu não apenas as forças repressoras de direita, mas também os até então colegas à esquerda. Isto porque o sujeito de Caetano Veloso não diz como deve ser feito, mas impele à ação, ao movimento, à experimentação, deixando o ouvinte livre para trilhar o próprio caminho.

Há um misto de ingenuidade e crueldade no sujeito que diz "quem sabe faz a hora", como se as possibilidades e oportunidades para fazer "acontecer" fossem iguais para todos os brasileiros. E como se a "revolução" fosse apenas uma questão de "vontade". Essa alusão à igualdade entre as pessoas nega a multiplicidade da multidão. É justamente desse todos-povo que o sujeito de "Alegria, alegria" vai se descolar, buscando percorrer caminho próprio de dor e delícia, desviando-se tragicamente do controle do Estado.

Se nas canções de Vandré o conteúdo político supera a tríade solar bossa-novista - flor, amor e dor - e glosa o "morro" e o "sertão", não deixa de ser curioso como isso contamina também o sujeito de Caetano Veloso que vai rimar "Brasil" e "fuzil", em detrimento do nacionalista "anil”. No entanto, a questão posta pela antropófaga Tropicália será: o que é raiz num país de culturas transplantadas? 
Outro ponto: descolar-se dessa canção cujo sujeito cancional toma para si a missão de "formar ideologicamente" o povo-ouvinte. Isso porque nas canções tropicalistas de que "Alegria, alegria" faz parte o empenho do sujeito é com a liberdade individual e a desconfiança do conceito "povo", "marchando indecisos cordões" à espera do guia messiânico mimetizado pelo sujeito de "Caminhando". Messias também evocado e projetado noutras canções, Vandré, por exemplo, na figura do "boi" que se torna "cavaleiro" e que, travestido de "boiadeiro", salvará o "nordestino": "Bem no fundo do coração / Guardo há tempos um cavaleiro / Que ainda vou mandar pro norte / Vestido de boiadeiro / [...] / E há um mundo inteiro / Que espera ouvir falar / De um bravo cavaleiro / Que bem soube se guardar / Para um dia lá no sertão / E no mar e em teu coração / Sertanejo ou jangadeiro / Trazer paz para o Norte inteiro" ("O Cavaleiro", de Geraldo Vandré e Tuca).

Em Caetano Veloso, mediação e representatividade são problematizadas quando o cancionista se depara com a ação de Paulo Martins, personagem do filme Terra em transe do cineasta Glauber Rocha. Lembremos: Paulo Martins, político à esquerda e poeta, tapa a boca de um líder sindical e diz: "Estão vendo quem é o povo? Um analfabeto, um imbecil, um despolitizado". A leitura que Caetano faz da cena é, aliás, duramente criticada por Roberto Schwarz no ensaio "Verdade tropical: um percurso de nosso tempo" (2012), em que o autor apresenta uma análise do livro de memórias de Caetano Veloso (1997). Escreve o cancionista: "quando o poeta de Terra em transe decretou a falência da crença nas energias libertadoras do 'povo', eu, na plateia, vi, não o fim das possibilidades, mas o anúncio de novas tarefas para mim" (p. 116). A catarse medicamentosa, veneno que cura, experimentada por Caetano fará o tropicalista romper com qualquer transcendência consoladora, bem como com o papel 
de mediador incorporado pelo "homem da terra" que persiste e luta contra a tirania e exploração latifundiária: "Eu que plantei muito e não tenho nada / Ouço tudo e calo na caminhada [...] Quanto mais eu ando, mais vejo estrada / Mas se eu não caminho eu não sou é nada" ("Ventania", de Geraldo Vandré e Hilton Acioli).

Para Rafael Julião (2017, p. 367),

a representação de povo brasileiro feita nesse universo político-ideológico (e não o povo em si) é posta em xeque no filme de Glauber, o que leva Caetano a rever aquelas posiçóes, que ele já vinha olhando com desconfiança desde antes, conforme exemplifica o artigo de 1965, em que defende a bossa nova a despeito do nacionalismo anti-imperialista de Tinhorão, ou contra as propostas de Augusto Boal no mesmo ano.

Por suavez, Roberto Schwarz (2012,p.77) escreve que "do ponto devistadaesquerda,acena - umainvençãoartísticadeprimeiraforçaera um compêndio de sacrilégios, fazendo uma espécie de chacota dolorosa das certezas ideológicas do período". Schwarz parece não compreender que para Caetano o gesto do poeta no filme se desdobrava no verso tropicalista "Não temos tempo de temer a morte", ou seja, o que era uma metáfora também era diagnóstico e precisava ser terapêutico.

$\mathrm{Na}$ única vez em que a palavra "alegria" do título aparece no plano discursivo-literário o que chama a atenção é que, ao invés de surgir dobrada, a "alegria" vem acompanhada de "preguiça" - pergunto: macunaímica? De repetir velhas formas de enfrentamento? A canção que vinha sendo executada em ritmo acelerado, condizente com o ir indo do sujeito cancional, desacelera, descontinua o caminhar se espreguiçando, o sujeito cancional alonga as vogais no exato momento em que o sol bate na banca de revista revelando o Sol - o jornal contracultural, contra a cultura do mesmo, do sufoco 
ideológico e das utopias. Esse procedimento rítmico também se dará quando o sujeito evocar "ela", a que "pensa em casamento" - "ela nem sabe até pensei / em cantar na televisão / o sol é tão bonito" ratificando a apreciação da luminosidade em tempos sombrios: ela/ televisão/sol, trindade promotora da singularidade do sujeito tropicalista no mundo de "amores vãos".

Sobre o título, Caetano (1997, p. 166) comenta que "havia a distância necessária para a crítica — para mim, uma condição da liberdade —, mas havia a alegria imediata da fruição das coisas”. E completa escrevendo que "essa consciência da alegria assim situada me levou a eleger como título (sem, contudo, incluir na canção) o cordão 'alegria, alegria!', que o animador de TV Chacrinha emprestara do bom cantor de samba-jazz em vias de aderir a um comercialismo vulgar (mas nem por isso menos delicioso) Wilson Simonal” (p. 166).

Destaquem-se ainda os versos "Sem lenço sem documento / Nada no bolso ou nas mãos / Eu quero seguir vivendo, amor / Eu vou" que fazem uma citação direta e desconstrutiva de Jean-Paul Sartre (1984, p. 183) quando este escreve que o que ama em sua loucura é que ela sempre o protegeu contra as seduções da elite: "nunca me julguei feliz proprietário de um talento: minha única preocupação era salvar-me - nada nas mãos, nada nos bolsos - pelo trabalho e pela fé". Ao mesmo tempo, a citação ajuda o sujeito caetânico a rejeitar também as flores dos hippies estadunidenses, já que suas mãos seguem vazias, livres. Este jogo lúdico e intertextual entre o testemunho e o questionamento problematiza os conceitos de arte engajada, participativa, empenhada, posto que "é a disseminação da luz que permite o esclarecimento de diversas questões naquele momento candentes. A tópica do desengajamento para poder enxergar o mundo sem filtro das posições preconcebidas era uma delas" (Tatit, 
2001, p. 189), reforçando o caráter cronístico — as marcas do tempo - dessas canções.

Por sua vez, os versos emparelhados - "saber", "acontecer" - do refrão de "Caminhando" apontam a intenção de unificar, ou seja, as rimas emparelhadas figurativizam o convite para que cantor e ouvinte sigam em uníssono. Diferentemente de "Alegria, alegria", cujo refrão - “Eu vou, por que não? Por que não?” — funciona mais como uma lírica intimidação do que um convite. Segundo Augusto de Campos (1978, p. 153),

no contexto maior da música popular brasileira, aquele 'Por que não?' do estribilho tomou características de um desabafo-desafio. E foi com esse sentido que o compositor, na primeira apresentação da música, triunfando sobre o desagrado com que um público preconcebido recebera o conjunto acompanhante dos Beat Boys, terminou, ao final, por proclamar, braços abertos à plateia conquistada: 'Por que não?'.

$\mathrm{Na}$ resistência da vida e sua afirmação trágica, um ("Caminhando") crê não ser reativo - porque supostamente convida todos, está aberto à alteridade - e é, o outro ("Sem lenço, sem documento") poderia se pensar reativo, por não se diluir na massa, e não é, posto que promove a alteridade.

Para Marcos Napolitano (2007, p. 127),

a busca constante de referências musicais e culturais revelava as vicissitudes de um artista [Vandré] que, mais do que outros, incorporou a tarefa de criação de uma canção 'de massa', engajada e exortativa, dentro das estruturas do mercado. Essa tarefa era incrementada pela radicalização do quadro político do país, 
que parecia impregnar o trabalho de Vandré mais do que o de outros músicos.

E completa destacando que

a partir de 1967, [Geraldo] tornou-se o músico brasileiro mais identificado com a versão brasileira da 'canção de protesto', superando Nara Leão. Essa mudança de referencial foi causa e efeito da grande popularização da MPB, entre fins de 1966 e 1968, cuja demanda requeria canções mais diretas e exortativas, inspiradas nas formas musicais anteriores à bossa nova (p. 127).

Lembremo-nos dos versos "O mundo foi rodando nas patas do meu cavalo / E nos sonhos que fui sonhando, as visões se clareando / As visões se clareando, até que um dia acordei" ("Disparada", de Théo de Barros e Geraldo Vandré). É esse sujeito esclarecido e desperto que toma para si a tarefa de tocar - aboiar - o levante popular. Mas isso não é manter o povo "gado"? O povo deixa de ser "gado" só porque quem está guiando agora é um sujeito "vindo do povo"?

Se Millôr Fernandes tratou "Caminhando" igual a "Marselhesa brasileira”, a canção repercutiu entre nacionalistas eruditos e militares. Para Tárik de Souza, "a esquerda desdenhava a música, achando-a pejorativamente cartática e desmobilizadora, enquanto a direita representada por militares dissecava ponto a ponto a composição, pedindo a prisão de Vandré pelos jornais por excesso de eficiência mobilizadora" (In Mello, 2003, p. 300). Jairo Severiano (1998, p. 125) lembra que

classificada pelo maestro Lindolfo Gaya como uma guarânia e pelo próprio Vandré como 'um rasqueado de beira de praia', 'Caminhando' mereceu do general Luís de França Oliveira, secretário de Segurança da Guanabara, o seguinte comentário, em entrevista que justificava a sua proibição: 'Pra não dizer que 
não falei de flores' tem letra subversiva e sua cadência é do tipo Mao-Tsé-Tung.

A passividade inebriante no tônus geral do ritmo da canção de Vandré, resultando na incoerência entre o que é dito e o modo de dizer, faz o andamento melódico ser o núcleo duro - a tensão ética e estética - que a distingue de "Alegria, alegria". A busca pela verdade finda por criar fugas da verdade. Tal incoerência será percebida e criticada em sua revolução conservadora tanto por Walnice Nogueira Galvão (1976), para quem "Geraldo Vandré é um especialista" da "Moderna Música Popular Brasileira [que] se caracteriza por uma intencionalidade informativa e participante" (p. 94) e a "esperança na MMPB, significa inação. Esperar significa postergar para o futuro. Vai implícita uma justificação do presente, em função da confiança na autonomia do futuro" (p. 97); quanto por Luiz Carlos Maciel (1968), que em artigo no Correio da Manhã escreveu sobre esse retorno à inércia: "O antimilitarista que cantou e aplaudiu 'Caminhando’ no Maracanãzinho saiu de coração lavado pela purgação de suas reservas agressivas. Quando, de volta pra casa, passou em frente ao Ministério do Exército, olhou-o com menos hostilidade e ressentimento: aliviara sua torturante sensação de impotência” (apud Nuzzi, 2016).

Ou seja, se o sujeito de "Caminhando" diz "vem, vamos embora", sua performance vocal o desdiz. O levante (euforia) proposto é vocalizado por um sujeito estático (disforia). A crítica social se limita ao plano do discurso. Em "Alegria, alegria", no entanto, o componente crítico aparece incorporado também ao ritmo e ao andamento da canção: “Eu vou!”.

A idealização da certeza (da verdade) é marca das canções de Vandré. Em "Vou caminhando" o sujeito diz que "Meu canto e meu riso / Não são pra enganar"; em "Disparada", temos "Se você não 
concordar não posso me desculpar / Não canto prá enganar"; e em "Porta-estandarte", "Deixa que a tua certeza se faça do povo a canção". Essa reiterada rejeição à mentira, ao engodo, à ambiguidade, ao tropo, ao canto das sereias, esse estar a serviço de uma mensagem clara, objetiva, direta, movimenta o sujeito empenhado em "consertar" o mundo. Jogar a certeza para o futuro consola o sujeito "de bem" que aspira ao conforto dominical burguês crente do processo linear e progressivo - não progressista! - da história.

Os sujeitos das canções "Alegria, alegria" e "Pra não dizer que não falei das flores" estão intimamente implicados com os acontecimentos em torno de seus cancionistas. As referências ao Sol e ao "soldado", respectivamente, enchem as canções de veracidade e crônica, mesclam autor, narrador e personagem numa única voz enunciativa. Na segunda, a "nova lição" será ensinada no futuro, na primeira não há lição, não há transmissão de ensino-conhecimento, há vivência. Conforme tentei expor, a linguagem discursiva direta e sua mensagem de significado rapidamente compreensível da segunda são desmentidas pelo ritmo passional e paralisante da canção; enquanto que na primeira há o experimento de uma ética da experiência.

A linguagem abstrata, fragmentada, impregnada do real, com foco mais no significante - esforço reflexivo individual - do que no significado - dado, fechado, transmitido, ensinado - de "Alegria, alegria" evoca o jogo entre identidade e alteridade, conforme entendido na canção de Caetano Veloso: falar de si ("eu vou”) é falar do outro ("vem, vamos embora"), este nós emerge como ponte entre o "eu" e "tu", mas esta ponte se estabelece no gesto mimético que ao outro é dado realizar.

Estamos em 2018. As flores que os artistas plantaram já não lhes pertencem. Os retornos contextuais dessas duas canções as- 
sombram o Brasil de hoje. Sejam nas estruturas messiânicas de "Pra não dizer que não falei das flores", que vai ser cantada, inclusive, em manifestações que pedem a volta da ditadura militar no país, mas também nas homenagens a Marielle Franco, vereadora (mulher, negra, periférica, lésbica) de esquerda executada em alarmante crime político, sejam nas urgências individuais e identitárias, o sufoco ético da década de 1960 ressurge em 2018, semelhante a um retorno do mesmo, carregado de rancor e recalque burguês e religioso: "Sol, a culpa deve ser do sol, que embaça os olhos e a razão", canta Chico Buarque em "Caravanas” (2017). 


\section{Referências}

ADORNO, Theodor. "Palestra sobre lírica e sociedade". In Notas de literatura I. São Paulo: Ed. 34, 2003.

CAMPOS, Augusto de. "A explosão de Alegria, alegria". In Balanço da bossa e outras bossas. São Paulo: Perspectiva, 1978.

CANDIDO, Antonio. “A vida ao rés-do-chão". In Para gostar de ler: crônicas. São Paulo: Ática, 2003.

GALVÃO, Walnice Nogueira. "MMPB: uma análise ideológica”. In Saco de gatos: Ensaios críticos. São Paulo: Livraria Duas Cidades, 1976.

HOLLANDA, Heloisa Buarque de. Impressões de viagem: CPC, vanguarda e desbunde: 1960/70. Rio de Janeiro: Aeroplano, 2004.

JULIÃO, Rafael. Infinitivamente pessoal: Caetano Veloso e sua verdade tropical. Rio de Janeiro: Batel, 2017.

MELLO, Zuza Homem de. A era dos festivais: uma parábola. São Paulo: Ed. 34, 2003.

NAPOLITANO, Marcos. Seguindo a canção: engajamento político e indústria cultural na MPB (1959/1969). São Paulo: AnnaBlume/ FAPESP, 2001.

NUZZI, Vitor. Geraldo Vandré: uma canção interrompida. São Paulo: Kuarup, 2016. 
OLIVEIRA, Leonardo Davino de. Canção: a musa híbrida de Caetano Veloso. Rio de Janeiro: Ibis Libris, 2012.

SARTRE, Jean-Paul. As palavras. Trad. J. Guinsburg. Rio de Janeiro: Nova Fronteira, 1984.

SEVERIANO, Jairo e MELLO, Zuza Homem de. A canção no tempo: 85 anos de músicas brasileiras, vol. 2. São Paulo: Ed. 34, 1998.

SCHWARZ, Roberto. "Verdade tropical: um percurso de nosso tempo". In Martinha versus Lucrécia: ensaios e entrevistas. São Paulo: Companhia das Letras, 2012.

SILVA, Alberto Moby Ribeiro da. Sinal fechado: a música popular brasileira sob censura. Rio de Janeiro: Apicuri, 2008.

TATIT, Luiz. "Alegria, Alegria”. In Análise semiótica através das letras. São Paulo: Ateliê Editorial, 2001.

TINHORÃO, José Ramos. Pequena história da música popular: Da modinha à canção de protesto. Petrópolis: Ed. Vozes, 1974.

VELOSO, Caetano. Verdade tropical. São Paulo: Companhia das Letras, 1997.

WOOLF, Virginia. Um teto todo seu. Trad. Bia Nunes de Sousa e Glauco Mattoso. São Paulo: Tordesilhas, 2014. 
Marcus Vinicius Nogueira Soares

Notas sobre a escrita da crônica no Brasil: 1830-1930 
A crônica é, em sua origem, um gênero jornalístico. Surgiu na França do século XIX e se espalhou imediatamente por diversos países dentro e fora do continente europeu. No Brasil, apesar da chegada tardia da tipografia, a crônica estabeleceu-se prontamente a partir do decênio de 1830, desenvolvendo-se rapidamente, em especial na imprensa da cidade do Rio de Janeiro. Em poucas décadas, já era um gênero consolidado, estampado nos principais jornais do país e praticado pelos mais célebres escritores da segunda metade do Oitocentos e de todo o século XX até hoje.

Isso não quer dizer que a crônica tenha permanecido restrita ao seu suporte de origem, o jornal. Embora não imediatamente, ela alcançou o livro ainda no período oitocentista, migrou para o rádio e a televisão no século seguinte e, no atual, é possível encontrá-la na internet, tanto em blogs quanto em redes sociais. ${ }^{1}$ Entretanto, apesar do trânsito entre suportes, a crônica continua frequentando assidua-

\footnotetext{
1 Destaco os seguintes exemplos: as crônicas de "Ao correr da pena", de José de Alencar, publicadas em livro em 1874; o programa da Rádio MEC, intitulado "Quadrante", de 1960; o quadro televisivo "Crônicas de Rubem Braga" no "Jornal Hoje" da Rede Globo, que foi ao ar entre 1975 e 1986; e os textos de Anderson França no Facebook.
} 
mente os jornais, convivendo de modo bastante produtivo com as suas diversas manifestações midiáticas.

Neste breve artigo, considerando apenas o desenvolvimento jornalístico da crônica, pretendo dar conta de diferentes momentos de sua escrita, com intuito de assinalar o percurso histórico do gênero na imprensa brasileira entre 1836 e 1936.

\section{Em 1836: no início era o folhetim}

Em 26 de novembro de 1836, em O Cronista, Justiniano José da Rocha (1836b, p. 1), depois de elogiar e agradecer aos seus instrumentos de ofício, a caixa e o tinteiro, escreve:

Realmente quem se mete no duro ofício de jornalista, quem se obriga a ter regularmente à sua disposição em horas certas e aprazadas, duas vezes por semana, ideias que interessem, expressões que as representem, quem se compromete a ter espírito e imaginação obedientes e dóceis como os membros do corpo (quando alguma paralisia, algum reumatismo, ou qualquer outro inconveniente lhes não vem a embargar os movimentos) faz dó, excita a compaixão se não sabe recorrer à sua caixa, e a seu tinteiro, se não sabe avaliar quanto lhe podem ser uteis esses socorros: às vezes lhe há de acontecer o que me aconteceu hoje, e o coitado não terá os recursos que tive.

$\mathrm{O}$ que se segue no artigo relata a dificuldade que o redator teve de produzir o seu texto, por conta do barulho produzido por um "concerto infernal" de gatos que o impediu de dormir durante a noite anterior. Pela manhã, com o impressor à sua porta cobrando-lhe os originais para levá-los à tipografia, o autor conseguiu prorrogar o prazo por mais duas horas. No entanto, devido à fadiga que o acometia, foi incapaz de ter sequer uma ideia. Foi quando ele recorreu à caixa de fumo e ao tinteiro que o auxiliaram na escrita. Depois de pitar e umedecer a sua pena no recipiente de tinta, apareceria um esboço 
inicial: "há de ser uma folha literária" (Rocha, 1836b, p. 2, grifo do autor). Com essa primeira delimitação, surgiu a dúvida: "mas qual será o seu assunto, qual a sua ideia geradora?” (p. 2). As possibilidades que então surgiram referiam-se aos acontecimentos que costumavam ser objetos da atenção do próprio jornal em outras colunas, como as que discutiam as ações governamentais, ou aludiam aos assuntos que eram geralmente tratados pela própria seção da qual "A caixa e o tinteiro" fazia parte, intitulada "Folha", cujo epíteto variava de acordo com o tema abordado, "literária", "crítica" etc.

Por sinal, esta seção era a mais recente novidade de $O$ Cronista: incorporada em outubro de 1836, ela correspondia ao "feuilleton" do jornalismo francês, um espaço disposto no rodapé da página, separado por um linha horizontal, no qual deveriam figurar os artigos que, como assinalava Justiano, serviriam de "sobremesa à vosso [do leitor] banquete de leitura" (Rocha, 1836a, p. 1); quer dizer, em oposição ao tratamento denso às igualmente densas matérias políticas, esses artigos versariam sobre as vicissitudes cotidianas de "diferentes classes de cidadãos" (soldados, juízes, funcionários públicos etc), serões familiares, bailes ou mesmo passeios em uma "bela noite de luar” (Rocha, 1836b, p. 3) em dicção mais amena e em tom de conversa com leitor. Assim, ao não se concretizar em sua pretensa realização, cuja escolha recaiu sobre o tema da "noite de luar", o texto que acabou sendo entregue ao impressor resultou em uma "conversação que tive com minha caixa, com meu tinteiro" (Rocha, 1836b, p. 2). Ainda que próximo da notícia, o folhetim que emergiu nos anos de 1830 estava bastante atento à esfera cultural do entretenimento, transformando-a em nova matéria jornalística. 


\section{Em 1850: ao correr da pena e dos eventos}

Em linhas gerais, pode-se dizer que a crônica desse período seguiu o caminho aberto nas décadas anteriores, mantendo-se ainda atrelada à notícia e responsável pelas informações relacionadas ao cotidiano cultural e político da cidade, em um universo jornalístico no qual prevaleciam os periódicos opinativos e doutrinários. Francisco Otaviano, José de Alencar e o jovem Machado de Assis, entre outros, trabalhavam não só comentando as notícias como também as produzindo, na medida em que se viam obrigados a participar efetivamente dos eventos que deveriam ser noticiados por eles.

Em crônica de 24 de setembro de 1854 de "Ao correr da pena", série hebdomadária publicada na seção "Páginas menores" do Correio Mercantil, o seu autor, José de Alencar (1854, p. 1), em face da grande quantidade de notícias surgida no domingo que abria a semana que deveria ser por ele contemplada em seu artigo, lamentava:

Entretanto a mim não me sucedeu o mesmo. Tinha-me divertido, é verdade; mas aquele domingo cheio, que estreava a semana de uma maneira tão brilhante, fazia-me pressentir uma tal fecundidade de acontecimentos, que me inquietava seriamente. Já via surgir de repente uma série interminável de bailes e saraus, um catálogo enorme de revoluções, e uma cópia de notícias capaz de produzir dois suplementos de qualquer jornal no mesmo dia. E eu, metido no meio de tudo isto, com uma pena, uma pouca de tinta e uma folha de papel, essa tripeça do gênero feminino, com a qual trabalham alguns escritores modernos, à moda do sapateiro remendão dos tempos de outrora.

Semelhante à função exercida pelo repórter do jornalismo moderno, competia ao cronista comparecer aos eventos da semana e apresentá-los em seu artigo, não à toa a série usava como subtítulo o termo "revista". Só que, além de relatá-los - e muitas vezes era o único relato que se encontraria de determinada ocorrência em todo 
o jornal -, ele deveria comentá-los, incluindo aí outros eventos que não contaram com a sua presença, e isso tudo no mesmo texto:

Obrigar um homem a percorrer todos os acontecimentos, a passar do gracejo ao assunto sério, do riso e do prazer às misérias e às chagas da sociedade; e isto com a mesma graça e a mesma nonchalance com que uma senhora volta as páginas douradas do seu álbum, com toda a finura e delicadeza com que uma mocinha loureira dá sota e basto a três dúzias de adoradores! Fazerem do escritor uma espécie de colibri a esvoaçar em ziguezague, e a sugar, como o mel das flores, a graça, o sal e o espírito que deve necessariamente descobrir no fato o mais comezinho! (Alencar, 1854, p. 1).

A passagem deixa entrever a tarefa a ser realizada pelo cronista que consistia em articular textualmente a diversidade dos assuntos com a variedade dos estilos sem perder de vista a graça e leveza de uma conversa de salão. No entanto, nem sempre essa articulação era possível, sobretudo quando havia entre os temas abordados um abismo entre os diferentes graus de afetação pública. Em crônica de 1 dezembro de 1861, na série "Comentários da Semana”, publicada no Diário do Rio de Janeiro, na tentativa de passar da notícia da morte do general Pereira Pinto para a apreciação crítica da peça A resignação, de Antônio Varejão, Machado de Assis (1861, p. 1) interpôs entre ambas uma sequência de pontos, escrevendo logo abaixo: "Esta linha de pontinhos significa que vou passar a assuntos de outro gênero, para os quais não achei uma transição capaz". Embora a exposição do motivo da utilização do recurso evidenciasse a sinceridade do cronista, ela não anulava a percepção da necessidade de se efetuar as transições intratextuais sem subterfúgios gráficos (afora os pontos, era comum o emprego da numeração, dos asteriscos, entre outros sinais), com intuito de se estabelecer certa coesão discursiva. 


\section{Em 1880: entre a crônica e a notícia}

A partir da década de 1880, com o desenvolvimento no Brasil do jornalismo noticioso, a crônica alcançaria certa autonomia na qual gradativamente prevaleceu a dicção do próprio cronista na sua capacidade de ler e comentar a notícia, como se percebe na produção machadiana desde então, sobretudo nas séries "Bons dias!" e "A Semana", ambas publicadas na Gazeta de Notícias entre 1880 e 1900. Como se não bastasse, o imperativo da ampla cobertura noticiosa da crônica diminuiu consideravelmente, a ponto de muitas vezes depender apenas da escolha autoral e o texto apresentar um único tema.

Em relação ao primeiro aspecto, posso exemplificar com uma crônica de "Bons dias!", de 12 de abril de 1888. Os assuntos noticiosos abordados pelo cronista eram os seguintes: a ação do $1 .^{\circ}$ Delegado de Polícia, Silva Matos, com intuito de melhorar o serviço dos bondes; as reviravoltas no caso da condenação de Pinto Júnior, acusado de assassinar Vitorino de Menezes; a “inexplicável” (Assis, 1888, p. 1) atitude de Bezerra de Menezes na indicação de um candidato liberal às eleições; a "denúncia" ao diretor do Museu Nacional a respeito de uma pedra de mármore com uma inscrição antiga encontrada na praça do Comércio. Nenhuma abordagem se deu mediante participação do cronista nos eventos ou era fruto de um trabalho de reportagem realizado por ele. Ao contrário, todos os temas foram retirados do jornal, a maioria da própria Gazeta de Notícias, consequentemente já se apresentavam como notícias devidamente configuradas por determinada diretriz jornalística. Sendo assim, nesse momento, a crônica machadiana estava muito mais ligada a um gesto de leitura e de escrita interpretativa do que à produção de notícia como se dera em meados do século XIX. 
Já quanto ao segundo aspecto, recupero texto de "A semana" de 9 de outubro de 1892. Transcrevo o seu início:

Eis aí uma semana cheia. Projetos e projetos bancários, debates e debates financeiros, prisão de diretores de companhias, denúncia de outros, dois mil comerciantes marchando para o palácio Itamarati, a pé, debaixo d’água, processo Maria Antônia, fusão de bancos, alça rápida de câmbio, tudo isso grave, soturno, trágico ou simplesmente enfadonho. Uma só nota idílica entre tanta cousa grave, soturna, trágica ou simplesmente enfadonha; foi a morte de Renan. A de Tennyson, que também foi esta semana, não trouxe igual caráter, apesar do poeta que era, da idade que tinha (Assis, 1892b, p. 1).

Praticamente todas as remissões feitas acima por Machado referiam-se a fatos associados ao episódio da crise econômica ocorrida à época, conhecida como Encilhamento. Já o "processo Maria Antônia" aludia ao violento assassinato de Maria de Macedo que vinha repercutindo intensamente nos jornais desde setembro, quando seu corpo mutilado foi encontrado no largo do Depósito. Por fim, a menção às mortes do poeta inglês Alfred Tennyson e do historiador francês Ernest Renan. Na verdade, enfastiado do falatório econômico e indignado com o sensacionalismo do noticiário policial, ${ }^{2} \mathrm{o}$ autor optou pela "nota idílica" sobre Renan. Nesse sentido, em Machado, a crônica não só deixa de ser matriz de notícias como também passa a selecioná-las, limitando o texto final à abordagem de um único tema e assumindo assim uma dicção ensaística, cada vez mais ao sabor da intervenção autoral.

2 Em crônica anterior, Machado já se mostrava incomodado, quando das primeiras notícias do caso, com a "fome" da população por "grandes crimes": "um simples pedaço de cadáver, ensopado em mistério, bastou a fartar toda a cidade" (Assis, 1892b, p. 1). 


\section{Em 1900: as novas tecnologias de comunicação e a crônica}

Com a modernização da imprensa no século XX, a crônica sofreria novas mudanças significativas. A ampliação do volume dos jornais, com a sua distribuição em diferentes suplementos, a maior incidência de imagens, especialmente de fotos, e a crescente profissionalização do trabalho jornalístico, em que se percebe maior especialização do jornalista, além do aumento de sua remuneração, foram conquistas trabalhistas e tecnológicas que contribuíram para a melhoria das condições de sobrevivência do homem de letras do período. Em face desse novo cenário do jornalismo brasileiro, embora continuasse algumas modalidades desenvolvidas no final do século anterior, especialmente as realizadas por Machado de Assis, a crônica novecentista retomaria determinados traços do gênero em seus primórdios, enquanto produto do espaço folhetinesco, como aquele que demandava a presença do cronista no contexto dos eventos a serem por ele noticiados, atualizando-os segundo as práticas jornalísticas contemporâneas. Assim, sem perder de vista a autonomia do gênero propagada por Machado, os escritores do Novecentos se acercaram cada vez mais do dia a dia das cidades, imprimindo em seus textos certa dicção que, em alguns casos, se aproximava da reportagem e, em outros, se distanciava, rumo a uma nova feição que só se consolidaria na década de 1930 e na qual prevaleceria a autonomia jornalística do gênero.

A produção de João do Rio era a que melhor representava essa mudança. Isso porque o autor de A profissão de Jacques Pedrei$r a$ transitava da reportagem para a crônica e vice-versa com extrema maestria. Ou seja, ele era tanto capaz de produzir investigações jornalísticas, que o tornaram um dos profissionais mais notáveis do período, quanto crônicas de intervenção, nas quais o escopo opinativo era preponderante. Como se sabe, João do Rio dedicou-se, entre fevereiro e abril de 1904, à pesquisa sobre diversas manifestações 
religiosas no Rio de Janeiro e à publicação na Gazeta de Notícias do respectivo resultado, na série intitulada "As religiões no Rio". Ainda no mesmo ano, ele enveredaria por outra série, "A pobre gente" e, em 1905, por mais duas: "O momento literário" e "No jardim do crime". Tratava-se de trabalhos de ampla reportagem investigativa, baseados na interlocução com os agentes em cena, mesmo quando o aparato da entrevista não aparecia em primeiro plano - o que ocorre em quase todos, com exceção de "O momento literário", cuja condução era praticamente toda dialogada. Apesar da finalidade informativa que regeu essas séries, o texto deixa entrever o gosto de João do Rio por uma dicção mais subjetiva e ornamental que melhor caracterizaria textos poéticos ou ficcionalmente orientados, como se percebe na passagem abaixo, transcrita do final do artigo "Os espíritas: entre os sinceros", de As religiões no Rio, que se refere à visita do autor a uma sessão na Federação Espírita Brasileira:

Desci as escadas devagar, aquelas escadas por onde subia sempre a romaria dos enfermos; na rua enxuguei a fronte, olhando o edifício menos misterioso que qualquer clube político. $\mathrm{E}$ como passasse um bonde inteiramente vazio, refleti que esse bonde podia bem ser como o do marechal Quadros e voltei, a pé, devagar, para não dar encontrões nas pessoas que talvez comigo tivessem passado todo aquele dia do outro mundo (Rio, 1904, p.1). ${ }^{3}$

Toda essa atividade jornalística de João do Rio tornou-o um dos homens de letras mais celebrados da época. Não demorou muito para que ele assumisse um lugar de destaque na Gazeta de Notícias, o de cronista da primeira página da edição dominical. Em 11 de agosto de 1907, utilizando o pseudônimo Joe, ele dava início à série

João do Rio aludia ao início do texto no qual citava um episódio, provavelmente uma anedota, em que o marechal Francisco Raimundo Ewerton Quadros, um dos divulgadores mais atuantes do Espiritismo no Brasil, teria deixado de pegar um bonde vazio porque ele estaria "cheio de espíritos maus" (Rio, 1904, p.1). 
"Cinematógrafo". No momento em que o jornal sofria significativas modificações, dentre as quais a adoção da imagem colorida, o texto de Joe ocupava boa parte da página, compartilhando-a com grandes gravuras em cores que sempre vinham estampadas na posição central da folha. Além disso, era repartido em itens, cada qual assumindo dicções variadas de acordo com o assunto abordado e ao mesmo tempo vinculado a um dia da semana que lhe servia de rubrica. $\mathrm{Na}$ edição inaugural, a distribuição foi a seguinte (apenas quarta-feira e sábado não foram mencionados no artigo): domingo, o acidente da lancha "Andorinha", cuja curiosidade pública pela morte da jovem Maria José Rodrigues Pereira levou o cronista a refletir sobre como "[era] superficial para a maioria o desaparecimento de uma vida" (Joe, 1907a, p. 1) - vale lembrar que o mesmo fato foi tema da gravura do dia; segunda-feira, o enfastio por mais uma reprise da revista Cá e lá..., no Teatro Recreio Dramático, produzida pela companhia do ator Dias Braga e o encontro no camarim da "boa camarada dos jornalistas” (p. 1), a atriz Helena Cavaller; terça, o ciclo de conferências na Associação Cristã dos Moços que, versando sobre o funcionamento das mais variadas carreiras profissionais, primava pela inteligência e utilidade, contrapondo-se à frivolidade que, em geral, graçava nesse tipo de atividade em grande voga à época; quinta, conversa com Carmem Dolores sobre a importância de visitar São Paulo, uma vez que, segundo o cronista, "se há Estado que lhe dê impressões de civilização, de país civilizado, é S. Paulo" (p. 1); sexta, relato de um episódio boêmio em que se percebe a dicção poética já aqui assinalada:

Quatro horas da manhã. O Rio ao amanhecer, guardando no negror do céu a chama apagada das estrelas. Sopra um vento glacial que dá convulsões aos oils e esmaece os combustores. Um rumor de folhagem, de árvores curvadas, de tristeza, de amargura passa pelos boulervards, e a candelária de luzes que 
se distribui pelos cais, pelos passeios marginais dos squares, tem qualquer coisa de funerário (Joe, 1907a, p. 1).

Considerando como João do Rio organiza o texto da série, é possível notar a recuperação da diretriz hebdomadária da crônica de meados do século anterior, inclusive com a inserção do corpo do cronista próximo aos acontecimentos por ele salientados, e, ao mesmo tempo, um distanciamento semelhante ao do "urso" machadiano finissecular, em que as notícias já não seriam mais tarefa indispensável do cronista, mas sim objetos de reflexão a partir de atos de leitura, sem contar os mais variados hábitos da vida urbana que se tornariam motivos para narrativas em que se manifestavam o apreço ao ornamento e, em alguns casos, certa ficcionalidade, como no último item do artigo de estreia. Acrescente-se a isso o modo como o autor de $A$ bela madame Vargas articulava a série com o fenômeno contemporâneo da cinematografia. Em crônica de 29 de setembro de 1907, ele demonstrava todo o seu entusiasmo pelo novo entretenimento:

Cinematógrafos... É o delírio atual. Toda a cidade quer ver os cinematógrafos. O carioca é bem o homem das manias, o bicho insaciável e logo saciado das terras novas. Toma um prazer ou um divertimento, exagera-o, esgota-o, aborrece-o e abandona$-\mathrm{o}[\ldots]$.

Cinematógrafos... Agora são os cinematógrafos. Em todas as praças há cinematógrafos-anúncios, ajuntando milhares e milhares de pessoas. Na Avenida Central, há dois, três, e a concorrência é tão grande que a polícia dirige a entrada e fica a gente esperando um tempo infinito na calçada (Joe, 1907b, p. 1).

As sessões contavam com a projeção de inúmeras cenas autônomas de gêneros diversos, do cômico ao patético passando pelo documentário. Para que se tenha a dimensão do funcionamento desses espetáculos, cito a estreia da empresa de Edouard Hervet no Teatro Lírico. Segundo anúncio publicado na Gazeta de Notícias de 28 de 
setembro de 1907, portanto um dia antes do artigo de Joe acima citado, seriam projetadas dezessete diferentes fitas, algumas coloridas e uma falada, ${ }^{4}$ distribuídas em três partes, intercaladas pela apresentação de peças orquestrais, regidas por Luigi Donati. A programação estava prevista para durar três horas. Para um espectador de hoje, pode parecer estranho a grande quantidade e variedade de projeções, mas, em geral, nesse primeiro estágio do desenvolvimento da cinematografia, as fitas eram curtas e nem sempre pautadas em enredos, ficcionais ou não, sobretudo no caso dos documentários, que se limitavam a registros de cenas banais do cotidiano.

João do Rio procurou apreender o fenômeno, elaborando uma série em que cada publicação dominical corresponderia, textualmente, a uma sessão de cinematógrafo e cada item uma fita projetada no interior de uma sequência cujo encadeamento não se estruturava segundo o estabelecimento de elos evidentes - o que era apresentado sob uma rubrica do dia da semana não encontrava continuidade nas seguintes. A dinâmica das salas do cinematógrafo, desde o rebuliço social que ela era capaz de produzir dentro e fora do espaço de projeção até a experiência do espectador em face da pluralidade e mesmo velocidade das cenas ou quadros que se desenrolavam diante de seus olhos, seria o substrato da linguagem cronística construída por Joe na série "Cinematógrafo".

\footnotetext{
4 Na verdade, os filmes "coloridos" eram colorizados na própria película, quadro a quadro, e não correspondiam ao efeito da captação da cor pela filmagem, ainda que essa tecnologia estivesse disponível pelo menos desde 1901, conforme descoberta recente. Já os filmes falados consistiam em um processo de sincronização da reprodução das imagens pelo cinematógrafo com a do som pelo fonógrafo.
} 


\section{Em 1930: a crônica moderna}

$\mathrm{Na}$ década de 1930, há um expressivo aumento da atividade jornalística e, no bojo desse crescimento, a crônica ganhava cada vez mais espaço na imprensa periódica. Em certa medida, isso pode ser creditado às grandes empresas de comunicação que, ao expandirem os seus domínios pelo território nacional, criando uma vasta rede de difusão através da articulação entre os principais veículos de massa da época (jornal, revista e rádio), acabaram por disseminar a crônica. Criado em 1924, no Rio de Janeiro, com a aquisição do periódico O Jornal, por Assis Chateaubriand, o grupo Diários Associados era o mais importante conglomerado do período. Foi nele que Rubem Braga apareceu, em 1932, para o público mais amplo, escrevendo para os jornais mineiros Diário da Tarde e Estado de Minas, ambos de propriedade do grupo. Esse vínculo não só permitiu que Braga trabalhasse em algumas das redações da empresa espalhadas pelo país, em cidades como São Paulo, Rio de Janeiro e Recife, como também possibilitou a circulação de seus textos nos periódicos das localidades nas quais o autor ainda não se encontrava presente - por exemplo, quando ele chegou à capital pernambucana em 1935, as suas crônicas já eram publicadas pelo Diário de Pernambuco, folha que pertencia aos Diários Associados.

Ademais, não só a imprensa periódica crescia como também o mercado de livros, em parte devido à própria disseminação da crônica. Em 1933, a jovem editora José Olympio lançava o volume de crônicas Os párias, de Humberto de Campos, um sucesso editorial. Aliás, o escritor maranhense, que se notabilizara pela produção sistemática de gêneros curtos para os jornais, vai ser o carro-chefe do crescimento vertiginoso da editora. Com a sua obra sendo publicada no decurso dos anos seguintes, sempre com boa repercussão de pú- 
blico, o seu nome acabou impulsionando a arrecadação da editora, mesmo após a sua morte em 1934. É bem possível que esse impulso tenha permitido a Olympio investir em nomes recém-consagrados da literatura nacional, mas ainda pouco conhecidos do público, como José Lins do Rego, Graciliano Ramos e Jorge Amado. Nem é preciso recordar que foi a mesma José Olympio que lançou, em 1936, o primeiro livro de Rubem Braga, $O$ conde e o passarinho, e que ainda seria responsável pelas outras coletâneas suas até os anos 1960, quando a Editora do Autor, de propriedade do cronista capixaba, passaria a publicar a sua obra. A crônica saía, assim, dos jornais para conquistar definitivamente as páginas dos livros. ${ }^{5}$

Como já aqui mencionado, foi neste momento que Rubem Braga apareceu para se tornar um dos mais importantes cronistas do século XX e praticamente estabelecer os parâmetros de escrita da crônica desde então. Para que se tenha uma ideia de sua expressiva contribuição, gostaria de destacar "Chegou o outono...", texto de seu livro de estreia, mas que foi primeiramente estampado em O Jornal, em 14 de abril de 1935. Nele o cronista assinalava a presença da nova estação por meio do relato de uma folha seca que, trazida pelo vento, atingiu fortuitamente o seu rosto, enquanto ele transitava pela rua Marquês de Abrantes, no Rio de Janeiro, a bordo de um reboque de bonde:

Não consigo me lembrar exatamente o dia em que o outono começou no Rio de Janeiro neste 1935. Antes de começar na folhinha ele começou na rua Marquês de Abrantes. Talvez no

\footnotetext{
5

Isso não quer dizer que a crônica já não participasse, mesmo que parcimoniosamente, do mercado editorial no século XIX, como se vê nas publicações de Alencar, Alfredo Bastos e Bilac. Nas duas primeiras décadas do Novecentos, o processo ganharia força tendo João do Rio à frente, contudo sem ainda atingir a amplitude mercadológica dos anos 1930.
} 
dia 12 de março. Sei que estava com Miguel em um reboque do bonde Praia Vermelha. (Braga, 1935, p. 1).

$\mathrm{Na}$ sequência, o cronista (p. 1) teceu considerações sobre a linha, pouco utilizada por ele, e seus usuários: "É o bonde dos soldados do Exército e dos estudantes de medicina”. Uma breve apreciação sobre a própria composição, o reboque de bonde, e logo adveio o encontro:

E quando entramos na Rua Marquês de Abrantes, rumo de Botafogo, o outono invadiu o reboque. Invadiu e bateu no lado esquerdo de minha cara sob a forma de uma folha seca. Atrás dessa folha veio um vento, e era o vento do outono. Muitos passageiros do bonde suavam (Braga, 1935, p. 1).

O cronista (p. 1) quis ainda saber a hora em que o evento se deu e perguntou ao passageiro ao lado, "um homem decentemente vestido, com cara de possuidor de relógio": "13:48. Agradeci e murmurei: chegou o outono". E, por fim, diante do que o cronista julgava ser desinteressante para o leitor no percurso de toda a viagem, escreveu: "O necessário é que todos saibam que chegou o outono. Chegou às 13:48 horas, na Rua Marquês de Abrantes e continua em vigor. Em vista do que, ponhamo-nos melancólicos" (p. 1).

Comparando com as crônicas anteriormente apresentadas, é possível observar que não há preocupação com o registro hebdomadário característico dos textos oitocentistas e retomado, de modo bastante peculiar, por João do Rio na série "Cinematógrafo". Na verdade, a crônica "Chegou o outono..." não se encontrava inserida em uma série, mas figurava autonomamente na primeira página da "Segunda Seção" da edição dominical de O Jornal, com o título em letras cursivas garrafais, seguido pela ilustração de Santa Rosa, localização e apresentação que podiam muito bem variar, como se deu, entre outras, com "O conde e o passarinho", impressa em meio às co- 
lunas da quarta página do exemplar de uma sexta-feira de fevereiro de 1935 e sem o acompanhamento de uma imagem ilustrativa. ${ }^{6}$ Essa ausência do registro hebdomadário fica mais acentuada quando se confronta o episódio assinalado por Rubem Braga com a quantidade de acontecimentos importantes que ocupava o noticiário daquela semana, da qual se destacam, em âmbito internacional, a Guerra Fria, a Guerra da Coreia, a disputa presidencial norte-americana entre o democrata Adlai Stevenson e o republicano Dwight Eisenhower, a crise do petróleo no Irã e, nacionalmente, a possível greve dos bancários, a provável desvalorização da moeda brasileira (cruzeiro), desmentida pelo ministro da fazenda Horácio Lafer, a eleição de Flores da Cunha para o governo do Rio Grande do Sul e o aumento salarial dos militares.

Ora, a abordagem de Rubem Braga desviava-se das notícias proeminentes para se debruçar na chegada do outono, evento que, embora socialmente compartilhado, costuma ser em geral percebido apenas por meio do registro que oficialmente marca a sua ocorrência, o calendário anual. Segundo este, em 1935, o outono principiaria a 21 de março.7 Como diferentemente se vê na crônica de Braga, a nova estação havia chegado "antes de começar na folhinha" e não se tratava de um fenômeno meteorológico, mas sim afetivo. Era sobre esse "clima" de afetividade coletiva que o cronista discorria, afetividade que poderia ser compartilhada por todos, inclusive por aqueles

6 Tomás Santa Rosa (1909-1956) foi cenógrafo e um dos mais importantes ilustradores da primeira metade do século XX, responsável por vários projetos gráficos para a editora José Olympio.

A data do início do outono foi também assinalada pela notícia do Correio da Manhã, de 22 de março de 1935, sobre a intensa chuva que caiu no Distrito Federal no dia anterior: "Entramos, ontem, no outono. Esse salto de estação foi ruidosamente assinalado, pela própria natureza, com um forte aguaceiro, que, como sempre, tudo alagou” (DE VERÃO..., 1935, p. 3). 
que, em seu dia a dia, não se davam conta de sua manifestação, distraídos como o "homem simples" do relógio, cuja única expectativa "era que o bonde chegasse a um determinado poste" (Braga, 1935, p. 1).

Boa parte do período em que Rubem Braga produziu - o autor faleceu em 1990 - coincidiu com o crescimento e valorização da crônica no jornalismo brasileiro, chegando, inclusive, como já aqui referido, a outros meios de comunicação de massa. A contribuição de Braga foi, sem dúvida, decisiva, sobretudo pela sua intensa dedicação ao gênero e pelo modo como ele deu sequência à tradição iniciada em 1836. 


\section{Referências}

ALENCAR, José de. "Ao correr da Pena". Correio Mercantil. Rio de Janeiro, p. 1, 24 set. 1854.

ASSIS, Machado de. "Comentários da Semana”. Diário do Rio de Janeiro. Rio de Janeiro, p. 1, 1 dez. 1861.

. “Bons Dias!". Gazeta de Notícias. Rio de Janeiro, p. 1, 12 abr. 1888.

. "A semana". Gazeta de Notícias. Rio de Janeiro, p. 1, 25 set. $1892 \mathrm{a}$.

. "A semana". Gazeta de Notícias. Rio de Janeiro, p. 1, 9 out. $1892 \mathrm{~b}$.

BRAGA, Rubem. “Chegou o outono.... O Jornal. Rio de Janeiro, 14 abr. 1935. Segunda Seção, p. 1.

DE VERÃO para o outono. Correio da Manhã. Rio de Janeiro, p. 3, 22 mar. 1935.

JOE. "Cinematógrafo". Gazeta de Notícias. Rio de Janeiro, p. 1, 11 ago. 1907a.

_ "Cinematógrafo". Gazeta de Notícias. Rio de Janeiro, p. 1, 29 set. $1907 \mathrm{~b}$.

RIO, João do. "Os espíritas: entre os sinceros". Gazeta de Notícias. Rio de Janeiro, 24 fev. 1904. As religiões no Rio, p. 1.

ROCHA, Justiniano José da. “Se porventura, amigo leitor.... O Cronista. Rio de Janeiro, pp. 1-2, 5 out. 1836a.

. "A caixa e o tinteiro". O Cronista. Rio de Janeiro, 26 nov. 1836b. Folha Literária, pp. 1-3. 


\section{Sobre os autores}

\section{Marília Rothier Cardoso}

Professora aposentada de Literatura Brasileira do Instituto de Letras da UERJ; atualmente, integra o corpo docente da área de Literatura do Departamento de Letras da PUC-Rio.

\section{Ana Chiara}

Doutora em Letras pela PUC-RJ. Professora associada de Literatura Brasileira na Universidade do Estado do Rio de Janeiro desde 1995, dedica-se à pesquisa nos seguintes temas: corpo, sexualidade, memória, escritas de si. Participa do GT ANPOLL de Literatura Comparada e Coordena o GPESq Vida, arte, literatura: bioescritas. Bolsista de Produtividade CNPq.

\section{Ana Lúcia M. de Oliveira}

Doutora em Literatura Comparada (UERJ, 1999), professora associada de Literatura Brasileira na UERJ, pesquisadora no programa PROCIÊNCIA UERJ/FAPERJ e bolsista de Produtividade em Pesquisa do CNPq. Traduziu e/ou coordenou a tradução de obras filosóficas, das quais se destacam: Caosmose, de Félix Guattari; Ensaios sofísticos e $O$ efeito sofístico, de Bárbara Cassin; Mil platôs, de G. Deleuze e F. Guattari. É autora de Por quem os signos dobram: uma abordagem das letras jesuíticas (EdUERJ, 2003) e organizadora dos livros Linhas de fuga: trânsitos ficcionais (7Letras, 2004); Antônio Vieira: 400 anos (EdUERJ, 2011); Cartas e papeis vários, tomo I, vol. 
5 da Obra completa do Padre Antônio Vieira (Lisboa: Círculo de Leitores, 2014; São Paulo: Loyola, 2014) e Figurações do real: literatura brasileira em foco VII (Relicário, 2016).

\section{Andréa Sirihal Werkema}

Professora adjunta de Literatura Brasileira da Universidade do Estado do Rio de Janeiro (UERJ), onde dá aulas na graduação, pós-graduação e especialização. Doutorou-se em Literatura Brasileira pelo Pós-Lit/UFMG. Publicou, entre outros, Variações sobre o romance (2016), Figurações do real (2017), A crítica literária brasileira em perspectiva (2013) e Macário, ou do drama romântico em Álvares de Azevedo (2012).

\section{Éverton Barbosa Correia}

Professor adjunto da Universidade do Estado do Rio de Janeiro (UERJ), fez estágio pós-doutoral inicialmente na UNESP e depois na UNICAMP. Sua tese de doutorado foi desenvolvida na Universidade de São Paulo (USP) sobre a obra de João Cabral de Melo Neto. Tem publicado em periódicos especializados artigos sobre autores da Literatura Brasileira, dentre os quais podemos destacar os seguintes: "Memória, genealogia e subjetividade em João Cabral" e "Um poema inédito na obra poética de Manuel Bandeira" (O Eixo e a Roda); "Apontamentos para leitura de poemas", "Dois poemas de Pedro de Alcântara - Dom Pedro II" e "O discurso de posse de um poeta-diplomata na Academia Brasileira de Letras e outros opúsculos" (Remate de Males); "Um baobá no Recife e o baobá do Senegal” e "Forma e subjetividade em dois poemas de João Cabral sobre o ovo" (Via Atlântica). 


\section{Fátima Cristina Dias Rocha}

Professora titular de Literatura Brasileira do Instituto de Letras da UERJ, instituição em que atua na Graduação e na Pós-Graduação. Neste âmbito, desenvolve pesquisa sobre as formas da autobiografia e do memorialismo de escritores brasileiros, publicando regularmente diversos artigos em torno desse tema. Em sua pesquisa mais recente, a pesquisadora investiga o autobiografismo contemporâneo, considerando-o, de um lado, em suas articulações e diálogo com a forte tradição autobiográfica que se consolidou no Brasil a partir da década de 1940; e, de outro lado, em seu convívio com a atual disseminação de narrativas vivenciais.

\section{Giovanna Dealtry}

Professora do PPG de Letras da UERJ. Doutora em Literatura Brasileira pela PUC-Rio, tendo publicado e coorganizado, entre outros, Guerreira, Coleção O Livro do Disco (Ed. Cobogó), O fio da navalha - malandragem na literatura e no samba (FAPERJ/Casa da Palavra) e O futuro pelo retrovisor - Inquietudes da literatura brasileira contemporânea (Rocco).

\section{Italo Moriconi}

Crítico e curador literário, editor, poeta e professor do Instituto de Letras da UERJ. Como curador, organizou algumas antologias marcantes, como Os Cem Melhores Contos e Os Cem Melhores Poemas Brasileiros do século XX (ambos pela ed. Objetiva), Destino: Poesia (ed. Jose Olympio) e a recém-lançada Torquato Essencial (ed. Autêntica, 2017). Coordenou o Café Literário da Bienal Internacional do Livro do Rio de Janeiro de 2009 a 2013. Chefiou a Editora da UERJ de 2008 a 2015, onde criou a prestigiosa coleção Ciranda da Poesia. Na área da pesquisa biográfica, publicou Ana C.: o sangue de 
uma poeta e organizou as Cartas de Caio Fernando Abreu, ambos agora em segunda edição pela Egalaxia. É autor de Como e por que ler a poesia brasileira do século XX (ed. Objetiva, Prêmio Livros Altamente Recomendados da FNLIJ).

\section{Leonardo Davino de Oliveira}

Professor adjunto de Literatura Brasileira na Universidade do Estado do Rio de Janeiro (UERJ). É doutor em Literatura Comparada pela UERJ, especialista e mestre em Literatura Brasileira. Ensaísta, procura refletir sobre as múltiplas e heterogêneas modalidades da poesia cantada, focado na vocoperformance da canção popular urbana mediatizada e suas produções e partilhas do sensível. É autor do blog Lendo canção (lendocancao.blogspot.com). É autor do livro Canção: a musa híbrida de Caetano Veloso (Ibis Libris, 2012); e, entre outros, coorganizador e autor do livro Palavra cantada: estudos transdisciplinares (EdUERJ, 2014).

\section{Marcus Vinicius Nogueira Soares}

Doutor em Literatura Comparada pela UERJ, é professor associado de Literatura Brasileira da mesma instituição. É coautor de "500 anos de ficção", publicado na Brasiliana da Biblioteca Nacional (Nova Fronteira, 2002) e autor do livro A crônica brasileira do século XIX: uma breve história (É Realizações, 2014). Membro do Grupo de Pesquisa LABELLE (Laboratório de Estudos de Literatura e Cultura da Belle Époque da UERJ), UERJ/CNPq. Publicou vários artigos sobre a crônica e a obra de José de Alencar em livros e revistas acadêmicas. 